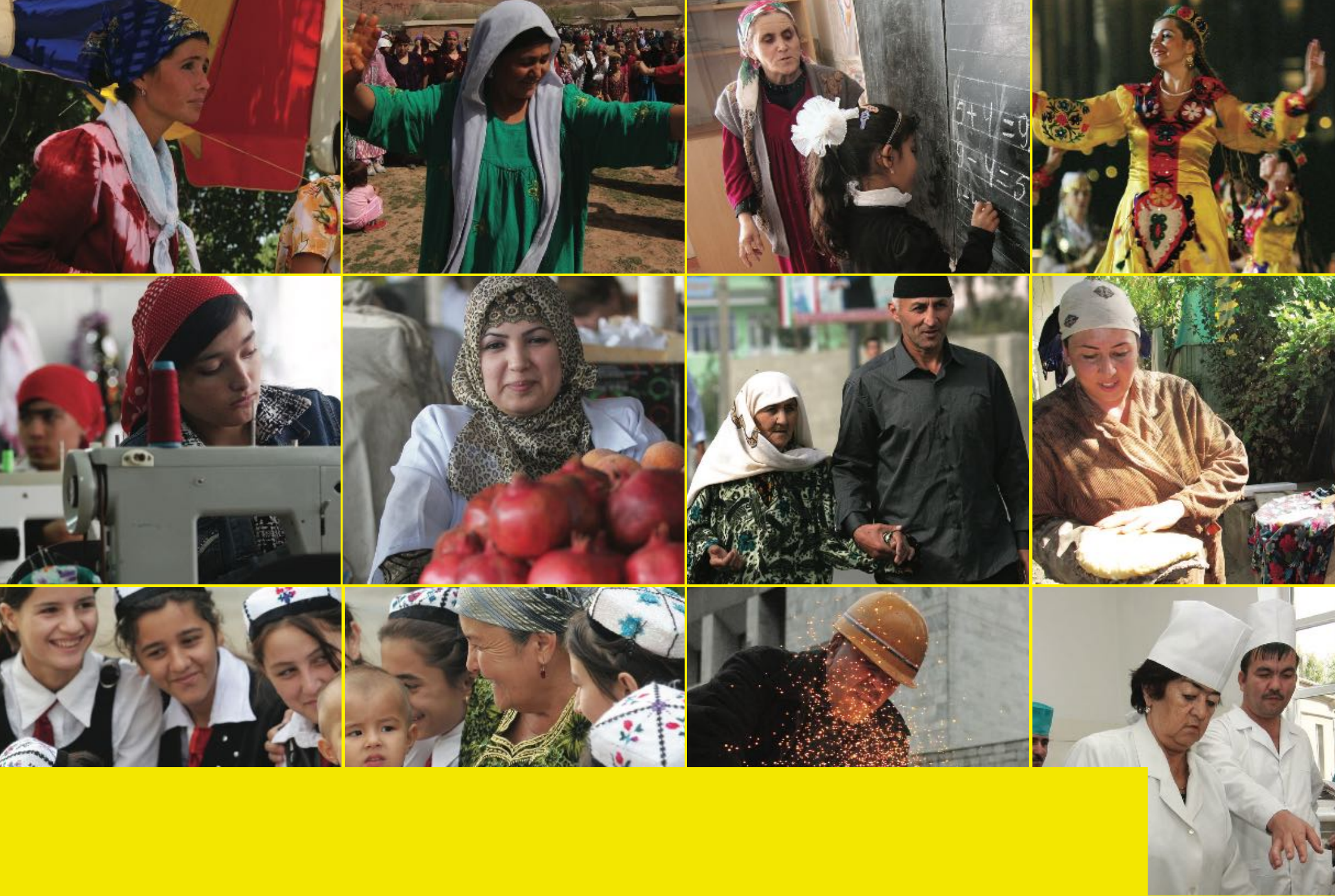

\title{
TAJIKISTAN \\ COUNTRY GENDER ASSESSMENT
}

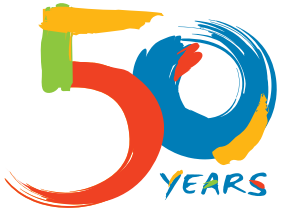




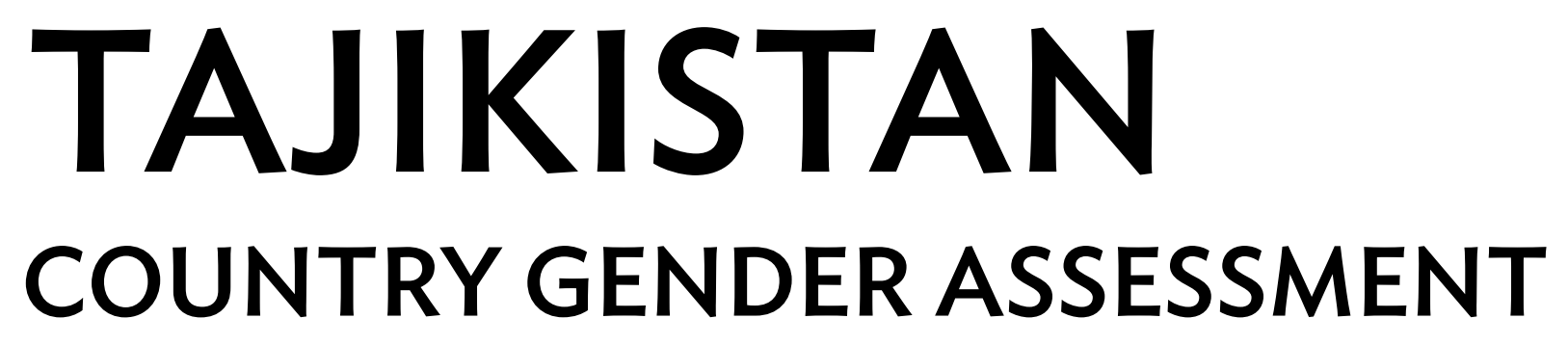


(C) 2016 Asian Development Bank

6 ADB Avenue, Mandaluyong City, 1550 Metro Manila, Philippines

Tel +632632 4444; Fax +6326362444

www.adb.org

Some rights reserved. Published in 2016.

Printed in the Philippines.

ISBN 978-92-9257-505-2 (Print), 978-92-9257-506-9 (e-ISBN)

Publication Stock No. RPT168187-2

Cataloging-In-Publication Data

Asian Development Bank.

Tajikistan country gender assessment.

Mandaluyong City, Philippines: Asian Development Bank, 2016.

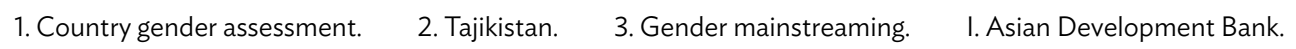

The views expressed in this publication are those of the authors and do not necessarily reflect the views and policies of the Asian Development Bank (ADB) or its Board of Governors or the governments they represent.

ADB does not guarantee the accuracy of the data included in this publication and accepts no responsibility for any consequence of their use. The mention of specific companies or products of manufacturers does not imply that they are endorsed or recommended by ADB in preference to others of a similar nature that are not mentioned.

By making any designation of or reference to a particular territory or geographic area, or by using the term "country" in this document, $A D B$ does not intend to make any judgments as to the legal or other status of any territory or area.

This work is available under the Creative Commons Attribution 3.0 IGO license (CC BY 3.0 IGO)

https://creativecommons.org/licenses/by/3.0/igo/. By using the content of this publication, you agree to be bound by the terms of this license.

This CC license does not apply to non-ADB copyright materials in this publication. If the material is attributed to another source, please contact the copyright owner or publisher of that source for permission to reproduce it. ADB cannot be held liable for any claims that arise as a result of your use of the material.

Attribution - In acknowledging ADB as the source, please be sure to include all of the following information:

Author. Year of publication. Title of the material. (c) Asian Development Bank [and/or Publisher].

URL. Available under a CC BY 3.0 IGO license.

Translations-Any translations you create should carry the following disclaimer:

Originally published by the Asian Development Bank in English under the title [title] ๔ [Year of publication] Asian Development Bank. All rights reserved. The quality of this translation and its coherence with the original text is the sole responsibility of the [translator]. The English original of this work is the only official version.

Adaptations-Any adaptations you create should carry the following disclaimer:

This is an adaptation of an original Work @ Asian Development Bank [Year]. The views expressed here are those of the authors and do not necessarily reflect the views and policies of ADB or its Board of Governors or the governments they represent. ADB does not endorse this work or guarantee the accuracy of the data included in this publication and accepts no responsibility for any consequence of their use.

Please contact publications@adb.org if you have questions or comments with respect to content, or if you wish to obtain copyright permission for your intended use that does not fall within these terms, or for permission to use the ADB logo.

Notes:

In this publication, “\$” refers to US dollars.

Corrigenda to ADB publications may be found at: http://www.adb.org/publications/corrigenda

Unless otherwise stated, figures and tables without explicit sources were prepared by the authors.

ADB recognizes "Kyrgyzstan" as the Kyrgyz Republic. 


\section{Contents}

List of Tables, Figures, and Boxes

Acknowledgments

vii

Currency Equivalents

ix

Abbreviations $\quad$ ix

Glossary $\quad$ x

Preface $\quad$ xii

Executive Summary $\quad$ xv

I. BACKGROUND AND CONTEXT

A. Gender Equality in the Post-Soviet Period 1

B. Measures of Gender Equality 4

C. National Legal and Institutional Framework $\quad 7$

1. Laws and Policies on Gender Equality

2 National Mechanisms 9

3. Data Collection: Statistics and Indicators 12

II. CRITICAL GENDER ISSUES 13

$\begin{array}{ll}\text { A. Women in Power and Leadership } & 13\end{array}$

1. Women in Politics and Public Office 14

2. Barriers to Women Entering Government 19

3. Engagement in Civil Society 21

B. Economic Opportunities for Women and Men 23

1. Poverty and Access to and Control over Assets 24

2. Economic Activity and Employment Patterns 26

3. Gendered Features of the Labor Market 27

4. Labor Migration and Changing Gender Dynamics 30

C. Gender Issues in Social Development 35

1. Intrahousehold Gender Dynamics 35

2. Gender Issues in Health 38

3. Gender-Based Violence 44

D. Women's Access to Justice 48 
III. MAINSTREAMING GENDER IN PROJECT OPERATIONS

A. Agriculture and Natural Resources

B. Education 60

C. Energy 69

D. Entrepreneurship and Enterprise Development 75

E. Transport $\quad 84$

IV. ENTRY POINTS FOR GENDER MAINSTREAMING

APPENDIXES

Appendix 1: Key Legal and Policy Developments 97

Appendix 2: Definitions of Gender and Development Terms 98

$\begin{array}{ll}\text { References } & 101\end{array}$ 


\section{List of Tables, Figures, and Boxes}

\section{Tables}

1. Tajikistan's Gender Inequality Index for 2013 relative to Central Asian Countries

2. Civil Servants in Selected Ministries, Committees, and State Agencies in Management and Specialist Posts, 2014

3. Proportion of Women in the Majlisi Oli, 2015

4. Proportion of Women in Local Executive Offices, 2010, 2014

5. Poverty Rates for Men and Women, and Male- and Female-Household Heads

6. Estimates of Household Drinking Water Sources

7. Proportion of Girls by Class and Province, 2013-2014 Academic Year

8. Selected Education Levels of Adult Men and Women 65

9. Cooking Fuel Used by Urban and Rural Households 70

10. Selected Household Goods Owned by Urban and Rural Households 72

11. Turnover Rates of Enterprises 76

\section{Figures}

1. Global Gender Gap Sub-Index Trends, 2007-2014

2. Tajikistan's Performance in the Social Institutions and Gender Index 2014 Sub-Indices

3. Proportion of Women in the Upper and Lower Chamber of the Majlisi Oli by Year, 2005, 2010, 2015

4. Employment Status of Men and Women, 2009

5. Distribution of Employed Women by Occupation, 2012

6. Women's Wages as a Proportion of Men's Wages, 2005-2014 29

7. Participation in Household Decision-Making 38

8. Trend in the Proportion of Dekhan Farms Managed by Men and Women, 2006-2014

9. Distribution of Student Enrollment by Type of Educational Institution, 2013-2014 Academic Year

10. Distribution of Male and Female Students in Higher Education by Academic Subject, 2013-2014 Academic Year 


\section{Boxes}

1. Tajikistan's First Female Presidential Candidate 17

2. Is Tajikistan Ready to Vote for Women? 20

3. Empowering or Burdening Women? 37

4. Women Living with HIV 42

5. Support for Women Survivors of Gender-Based Violence 46

6. Technical and Vocational Education and Training in Tajikistan 66

7. Grants for Women Entrepreneurs 84

8. Transport-Related Issues for Women Market Traders 89 


\section{Acknowledgments}

This country gender assessment was researched and written by Elisabeth Duban.

The assessment was prepared under Asian Development Bank (ADB) regional technical assistance (RETA) 7563: Promoting Gender Inclusive Growth in Central and West Asia Developing Member Countries. The assessment process was supervised by the Central and West Asia Department's gender and development team comprising Shanny Campbell (senior social development specialist on gender and development), Jeremy Stickings (senior social development specialist on gender and development), Mary Alice Rosero (gender and social development specialist consultant), Wilma Silva-Netto Rojas (gender and development consultant) and Gulnora Kholova (gender and development implementation consultant at the Tajikistan Resident Mission).

Special mention is made of the role played by Barno Kurbanova, the national researcher and gender consultant whose organizational skills, research support, and facilitation of focus group discussions were vital to the assessment.

The author would like to convey deep appreciation to several individuals and their organizations who identified active women among their stakeholders to participate in focus group discussions in the following locations:

- Dushanbe: Nargis Yuldasheva, executive director of NGO Sarchashmai Hayot (Source of Life); and Yuri Skochilov, executive director, Youth Ecological Centre;

- Garm: Jamila Sharifova, field office assistant, Organization for Security and Co-operation in Europe Field Office (Garm); and Shahlo Shoeva, senior gender program assistant, OSCE Office in Tajikistan (Dushanbe);

- Khujand: Firuza Rahmatova, manager of TWEET (Tajik Women Empowerment) business incubator project; and Malika Mirzobakhodurova, deputy general director, National Association of Business Women of Tajikistan (NABWT);

- Kurgan-Tube: Zuhro Murodova, area program manager (Khatlon); and Shakhlo Yarbaeva, monitoring and evaluation adviser (Dushanbe), Save the Children, Women's Wealth and Influence Project;

- Nau: Surayo Saidova, Agency for Support Development Process Nau (ASDP Nau), project manager, "Empower Women Benefit for All" Project; and Anke Stock, senior specialist, gender and rights, Women in Europe for a Common Future-Women International for a Common Future (WECF/WICF); and

- Panjakent: Fotima Sharipova, chair, NGO Zanoni Sharq (Women of the East); and Zukhra Sharipova, director, NGO Madad.

We are grateful to all the focus group discussion participants and to the experts who took part in the consultations. These individuals were not merely generous with their time, but, 
more importantly, showed their commitment to improving the lives of women in Tajikistan through their serious engagement with the ADB gender assessment process. Farogat Tadzhibaeva provided valuable interpretation during focus group discussions.

The report benefited from the constructive inputs of sector specialist peer reviewers, as well as gender and development specialists at ADB headquarters in Manila.

Finally, we dedicate this report to Shireen Lateef (ADB senior advisor for gender until July 2015), whose legacy continues to inspire us to stay true to the commitment of improving women's lives, addressing gender inequalities, and cultivating an enabling environment for women's empowerment. Ms. Lateef paved the way for the institutionalization of gender mainstreaming in ADB. The country gender assessment is one of the more important results of ADB's gender mainstreaming policy and strategy, together with the implementation of the Guidelines on Gender Mainstreaming Categories during project design. 


\title{
Currency Equivallents
}

As of 1 April 2016

\author{
Currency Unit - Somoni (TJS) \\ TJS1.00 - \$0.13 \\ $\$ 1.00$ - TJS7.91
}

\section{Abbreviations}

$\begin{array}{ll}\text { ADB } & - \text { Asian Development Bank } \\ \text { CEDAW } & - \text { Convention on the Elimination of All Forms of Discrimination against } \\ \text { CGA } & - \text { Women } \\ \text { CSO } & - \text { country gender assessment } \\ \text { DPO } & - \text { disabled persons organization } \\ \text { DRS } & - \text { Districts of Republican Subordination } \\ \text { FGD } & - \text { focus group discussion } \\ \text { GAP } & - \text { gender action plan } \\ \text { GBAO } & - \text { Gorno-Badakhshan Autonomous Province } \\ \text { GBV } & - \text { gender-based violence } \\ \text { GDP } & - \text { gross domestic product } \\ \text { GII } & - \text { Gender Inequality Index } \\ \text { IDU } & - \text { injecting drug user } \\ \text { IOM } & - \text { International Organization for Migration } \\ \text { MDG } & - \text { Millennium Development Goal } \\ \text { MP } & - \text { member of parliament } \\ \text { NGO } & - \text { nongovernment organization } \\ \text { OECD } & - \text { Organization for Economic Co-operation and Development } \\ \text { PWDs } & - \text { persons with disabilities } \\ \text { SIGI } & - \text { Social Institutions and Gender Index } \\ \text { SME } & - \text { small and medium-sized enterprise } \\ \text { SRH } & - \text { sexual and reproductive health } \\ \text { STI } & - \text { sexually transmitted infection } \\ \text { TjDHS } & - \text { Tajikistan Demographic and Health Survey } \\ \text { TVET } & - \text { technical and vocational education and training } \\ \text { WUA } & - \text { water users' association } \\ \text { STE } & \end{array}$




\title{
Glossary
}

\author{
dekhan farms \\ - Mid-sized, privately owned commercial farms that are \\ distinct from household plots; also referred to as "peasant \\ farms." Dekhan farms can be individual, family, or \\ collective farms. \\ hectarchi \\ - Seasonal work with output-based wages that are paid in \\ cash or in-kind \\ hukumat \\ - Local executive authority at the municipal, district, or \\ regional level. \\ jamoat \\ - Local self-government body at the subdistrict level. The \\ third level administrative division that consists of several \\ villages or settlements, approximately equivalent to a \\ municipality. \\ mahalla \\ - Community council. The mahalla is not an official \\ structure of local self-government; nevertheless, \\ it organizes and carries out important community \\ functions. \\ majlisi \\ - Assembly or council. Representative body of people's \\ deputies at the regional, city, and district levels. \\ Majlisi Milli \\ - National Assembly, upper house of Parliament \\ Majlisi Namoyandagon \\ - Assembly of Representatives, lower house of Parliament \\ Majlisi Oli \\ - Supreme Assembly. The bicameral national parliament of \\ Tajikistan. \\ mardikor \\ - Short-term and flexible output-based work that can be \\ completed on any farm \\ marshrutki \\ - Private microbuses \\ mirob \\ - A local water master who controls irrigation \\ nikoh \\ - Muslim rite of marriage registration
}


nohiya

raion

sahimdor

sotka

viloyat
- District. Each province is divided into districts; of the 62 districts in Tajikistan, four are in Dushanbe. The Russian word "raion" is also used in Tajikistan.

- Russian translation of nohiya, a district.

- Collective owners: effectively, an employee position with an obligation to work on the collective farm for a monthly cash salary

- 100 square meters

- Province. Tajikistan has four political divisions: Dushanbe, the capital; two provinces (Sughd and Khatlon); one autonomous region (Gorno-Badakhshan Autonomous Province); and the Districts of Republican Subordination. The Russian word "oblast" is also used in Tajikistan. 


\section{Preface}

The Asian Development Bank (ADB) has partnered with the Government of Tajikistan for over 15 years. During this time, ADB has supported assessments and studies on the status and role of women in Tajikistan to assist its staff in mainstreaming gender concerns in its projects. Such studies also contribute to the body of Tajik gender and development research. ' This country gender assessment (CGA) builds upon a previous assessment published in 2006, as well as ADB's experience in support of gender equality and women's empowerment in Tajikistan.

This CGA is a stand-alone document, but it also informs ADB's gender strategy in the Tajikistan 2016-2020 Country Partnership Strategy. The CGA highlights key constraints to gender equality both regionally as well as in the specific sectors and operations areas that ADB has prioritized: transport; energy; public sector management; technical and vocational education; climate change adaptation; water resource management and food security; and private sector operations.

Many of the gender equality barriers encountered in the ADB priority sectors stem from deeper structural disparities; differential access to and control over assets, resources, employment, and social protection; and women's ability to influence decision making. For this reason, the CGA reviews several cross-cutting gender equality and women's empowerment issues.

In addition, because of the CGA's participatory methodology, described below, gender experts and focus group discussion (FGD) participants raised several of the topics included in this report directly. Each is considered particularly critical to achieving gender equality in Tajikistan.

\section{Methodology}

The assessment used a methodology comprising in-country consultations, FGDs, and a review of secondary source material, with initial consultations being conducted in late 2014 with gender experts and gender focal points from 25 institutions mainly located in Dushanbe: nongovernment organizations (NGOs), international development organizations, and the Committee for Women's and Family Affairs. The consultations were meant to confirm preliminary findings from the literature review and to identify gender equality and women's empowerment priorities for future projects. The individual

1 See, e.g., ADB. 2000. Women and Gender Relations in Tajikistan: Country Briefing Paper. Manila. http://www.adb.org/documents/ women-tajikistan-country-briefing-paper 
consultations were also an opportunity to gather information about good practices and lessons learned from other development projects with gender themes.

FGDs were a central part of the assessment and a means to hear from women about issues they face in their communities. Six FGDs canvassed women in locations representing areas covered by current ADB projects, as well as potential areas: (1) Dushanbe, ${ }^{2}$ (2) Rasht [Districts of Republican Subordination], (3) Khujand, (4) Panjakent, (5) Nau [Sughd viloyat], and (6) Kurgan-Tyube [Khatlon viloyat]. In each group, participants came from several raions (16 in total). Across all focus groups, residents of two cities, 22 jamoats, and 16 villages participated. The choice of FGD locations coincided with the presence of active NGOs and international organizations with women-focused projects. These organizations assisted in identifying stakeholders who had knowledge of local gender conditions.

A total of 85 women took part in the FGDs, with an approximately equal number attending each discussion. The participants ranged from students to retirees, with the following age distribution: $8-30$ years (8\%); $31-40$ years (27\%); $41-50$ years (30\%); $51-60$ years (29\%); and 61-70 years (6\%). Two of the FGDs targeted women with specific professions: entrepreneurs (Khujand), and dekhan farmers (Kurgan-Tyube). Excluding these two groups, most of the participants work for NGOs or in the education sector or are not currently in formal full-time employment (they described themselves as "housewives"). Several participants work in government offices (for example, heads of women's councils at the jamoat level), as seamstresses in small workshops, or in healthcare. The majority of focus group participants were ethnic Tajik women, but FGDs held in Dushanbe and Nau featured many Uzbek women.

The participants not only identified critical gender issues in their communities and the country as a whole, but also provided information about their personal involvement in businesses, income-generating activities, renewable energy projects, training courses, and community-based volunteer work. The FGDs provided insights into how women are impacted by poverty and infrastructure problems and their specific needs-information that is generally lacking in assessments conducted in Tajikistan. Participants themselves drew attention to women, "lack [ing] a public voice," though when given the opportunity to express their opinions, women do have distinct perspectives about their country. The focus groups were meant to explore women's opinions on several development issues, including gender, in sectors where ADB operates.

\section{Note about diversity within "gender"}

While this assessment examines gender equality, it did not view women and men as homogeneous groups. The experiences and priorities of diverse groups of men and women have always been considered. Factors such as age, socioeconomic status, ethnicity, location, disability, and refugee status can all affect the relative status of both women and men. Wherever relevant and possible, this assessment includes specific information about girls, women with disabilities, and women living with HIV. Very limited information

2 Note that participants of the focus group discussion held in Dushanbe are not residents of the capital, but come from four raions that are implicated in ADB's road rehabilitation project between Dushanbe and Tursunzade. 
was available about ethnic minority or refugee women beyond their possibly facing greater exclusion from basic social services, education, and employment than other women.

Official Tajikistan data reveal that some indicators and trends vary by region. While some respondents characterized certain regions as having more conservative and traditional views, others maintained that the most critical gender issues are shared by the country as a whole. The assessment's methodology did not allow for a comprehensive analysis by region, but the research and FGDs did indicate that there are marked differences between urban and rural women's status and opportunities. 


\section{Executive Summary}

Like other former Soviet republics, Tajikistan inherited an ideology that supported equal rights for women and men when it declared independence. Traditional patriarchal patterns of family and social life reemerged in the early transition years as the country moved away from its Soviet past. This was exacerbated by a devastating civil war that left an estimated 25,000 widows, 55,000 orphans, and almost one million displaced persons. Immediately following the civil war, girls were married off before they completed their education, resulting in a generation of women with less education than their mothers and who are repeating the cycle with their own children. These conditions contributed to a resurgence of conservative values observed in post-Soviet and post-war Tajikistan, as shown by an increase in early marriages, polygamy, and women's restricted public lives.

Tajikistan ranked $102^{\text {nd }}$ out of 142 countries in the World Economic Forum's 2014 Global Gender Gap Index, with a score of 0.665, indicating limited progress from its 2007 score of 0.658 . While its scores for educational attainment and for health and survival are relatively high, scores for both economic participation and opportunity (labor force participation, wage equality, and the numbers of senior, professional, and technical workers) and political empowerment (women in parliament and ministerial positions) are low, and offset the other positive indicators of equality.

The national framework for gender equality, specifically the Law on State Guarantees of Equal Rights and Opportunities for Men and Women, lacks clear implementation processes. Other laws aim at protecting women's rights and security, such as those combating human trafficking, preventing domestic violence, and raising the legal age of marriage to 18 years. A national gender policy was passed in 2010, the National Strategy for Enhancing the Role of Women in the Republic of Tajikistan, which lists concrete actions to improve women's participation in education, the labor market, entrepreneurship, and in politics, albeit without identifying responsible agencies, timeframes with milestones, funding sources, and monitoring plans.

The primary institution responsible for gender policy is the Committee for Women's and Family Affairs (Women's Committee), which has diverse functions ranging from conducting research to considering complaints from citizens, promoting women's rights through the media, monitoring international standards compliance, coordinating the work government and nongovernment bodies do on gender equality, and training. The Women's Committee operates 110 regional information-consultation and crisis centers throughout the country, funded through local budgets. A network for gender mainstreaming also links seven ministries and agencies, including the Women's Committee. Although its financial and human resources have been increased, the Women's Committee still has limited capacity to carry out its mandate and relies on international donor agencies. Furthermore, 
much national gender policy work is not made manifest locally, and gender mainstreaming is sporadic in subnational development planning.

The collection and reporting of gender statistics is the responsibility of the Agency for Statistics under the President of the Republic of Tajikistan (Statistics Agency), which has consistently published the Women and Men of the Republic of Tajikistan compilation. In 2013, the Statistics Agency adopted an internal work plan, the Program on the Development of Gender Statistics in Tajikistan for 2014-2015, which prioritized the regulatory framework relevant to gender statistics, capacity building of national and local experts, and improving the production, dissemination, and use of such statistics.

\section{Women in Power and Leadership}

Women's political participation remained low in 2015 , with only $19 \%$ of parliamentarians in both lower and upper houses. The total number of women in central and local civil service stood at 4,393 (23.5\%) in 2014. The figure for women in leadership positions is smaller, with only 528 women, or $17 \%$, heading central agencies and their attached structures. Women's political participation improves at the local level, with $40 \%$ of jamoat chairpersons being female. No political party quotas exist for women, nor are there leadership trainings for their political participation. Stereotypes of women as homemakers conflict with images of women as political leaders, which are typically seen as men's roles. Civil society, via NGOs, community-based organizations, and other women's organizations, offers women an avenue to take part in national reforms and employment opportunities, and to engage on public issues.

\section{Economic Opportunities for Women and Men}

Since 2009, Tajikistan has experienced a reduction in poverty, but rates still remain high. There are no differences in the relative rates for men and women, but female-headed households are more at risk for poverty and extreme poverty than households headed by males. National surveys indicate that households headed by females are less likely to have valuable goods such as cars, trucks, computers, land, and livestock. Given that the number of households headed by females appears to be increasing, women's limited access to and control over assets has serious repercussions for a considerable portion of the population.

The female labor force participation rate is $45 \%$ and varies by region. Women are disproportionately represented in healthcare (58.7\%) and education (53.7\%), where average earnings are lower than other professions. Agriculture consists of $48 \%$ women workers, but the figure could be higher if all the unpaid women who work alongside their husbands were counted. Women are also in low-skilled work and occupations, as well as informal employment, which directly translates to disparities in earnings. In 2013, women's average monthly wages were only $63.3 \%$ of men's, which is already an improvement over the last decade. It is not clear whether the narrowing wage gap is due to salary increases for women or to decreasing men's wages. Only part of the gender wage gap can be accounted for in 
variables such as differing employment patterns. Gender discrimination and stereotypes also figure in women's lower pay as they are assumed to have other sources of support.

Male and female employment patterns differ: according to the most recent Labor Force Survey, men's level of economic activity is almost double that of women. The majority of the economically inactive female population is between the ages of 25 and 49; the sharp decline in women's economic activity at this age corresponds directly to when they leave the labor market, marry, start families and have increased household obligations. In addition to domestic task distribution inequalities, women's generally lower level of education (especially vocational education), lack of professional qualifications, and high fertility rate combine with the absence of childcare facilities and gender stereotypes to place women in a weak employment position. Even among the working population, women are more commonly members of producers' cooperatives, as compared to men who generally work as employers or are self-employed (as own-account workers). A considerable segment of the population works in informal employment, and the majority of such workers are men. Still, many women work informally doing hard physical agricultural labor for long hours, in poor working conditions, and with a lack of such social protections as maternity leave and pension payments.

In 2014, men aged $18-39$ accounted for $71 \%$ of male migrants to the Russian Federation. Most men who migrate are married ( $90.2 \%$ according to one survey), but they rarely travel with their wives (only $4.9 \%$ of male migrants did so in 2010). Men are driven to migrate because of limited employment opportunities in Tajikistan that would enable them to support their families, and migration has come to be seen as a "male" occupation. While women also migrate for work, migration has a significant impact on those women who remain behind. Despite labor migration having expanded women's roles, it does not appear to have affected their status in terms of increased agency and ability to make autonomous personal choices. The situation of women and children considered "abandoned" by labor migrants is a particular concern, as such families are usually impoverished and may risk domestic exclusion.

Many families depend on labor migrant remittances. According to the World Bank, remittances accounted for 48\% of gross domestic product (GDP) in 2013. On average, the poorest rural and urban households finance close to $80 \%$ and $50 \%$, respectively, of their yearly consumption through remittances. Studies indicate that, even in households in which remittance transfers are regular, women are less likely to have control over how such funds are spent. Labor migrants most frequently send remittances to the household head, typically their fathers or mothers, rather than their wives. Because women have limited bargaining power, their welfare, or that of their children, may be neglected in favor of other household expenditures. Wives of labor migrants frequently aim to augment the household budget with supplemental labor, but usually do not exercise sole control over their earnings.

\section{Intrahousehold Gender Dynamics}

Approximately $36 \%$ of households consisted of multigenerational families, the most common pattern being two or more married couples, with or without children, living with other relatives, most typically consisting of an adult couple, their unmarried daughters, 
and married sons with their wives and children. Gender roles are quite well-defined, with the oldest active male family member considered the head of the household and family breadwinner, and female members in more subordinate roles. Surveys from 2003 and 2007 of women's time dedicated to unpaid activities indicate that they spent over 32 hours per week on various household chores and caring for family members. The 2012 Tajikistan Demographic and Health Survey (TjDHS) revealed that more than half of the surveyed women exercised some decision-making concerning their own healthcare, major household purchases, and visits to their own families or relatives, but $34.2 \%$ responded that they did not participate at all in any of the decisions. Husbands and other male members have more inputs in decisions than their wives, and men are more likely to make decisions independently than women.

\section{Health Issues}

The Government of Tajikistan has made important investments in maternal health to achieve the Millennium Development Goal (MDG) 5. Data from the Ministry of Health placed the 2012 maternal mortality rate at 33.3 per 100,000 live births. Official statistics placed the proportion of pregnant women receiving antenatal care at $88 \%$ in 2012, as compared to $70 \%$ in 2008 . The 2012 TjDHS reported that $78.8 \%$ of women had received antenatal care at least once from a skilled provider in the five years preceding the survey. While the number of women receiving antenatal care has increased and maternal mortality has decreased, the rate still remains high compared to other countries in Central Asia and the Commonwealth of Independent States. Various preventable factors contribute to maternal mortality and poor birth outcomes, including limited access to medical services, inadequate existing services, poor health, and women's and family members' limited awareness of danger signs for high-risk pregnancies. Early pregnancy exacerbates such factors, which are also reflected in the high number of home births, many of which take place without adequate medical assistance.

Over a quarter of currently married women are using some form of contraception (primarily, the IUD), but female contraceptive use has declined from 38\% in 2005 to 28\% in 2012. Young people often cannot access sexual and reproductive health (SRH) services due to their lack in rural areas, lack of income to purchase contraceptives, parental consent requirements, taboos about discussing sexuality, and the lack of medical providers of the same sex (a problem for both male and female youth). SRH services are also needed to arrest the spread of sexually transmitted infections (STI), including HIV. There were 4,581 people living with HIV in Tajikistan (69.8\% male and 30.2\% female) in 2013. Men with HIV are generally between $30-39$ years old (46.4\% of the male HIV-positive population), while women are younger; $42.4 \%$ of women with HIV are ages $19-29$. The most common transmission route for women is through sexual contact ( $80 \%$ of cases), while men are almost equally likely to become infected through sexual contact (43\% of cases) and injecting drugs ( $42 \%$ of cases). 


\section{Gender-Based Violence}

Estimates of the prevalence of domestic violence range from one-third to one-half of women in Tajikistan having regularly experienced physical, psychological or sexual violence. The 2012 TjDHS disclosed that, in a sample of more than 4,400 women ages 15-49, almost one in five reported having experienced emotional, physical, or sexual violence from their husband (19\%); $13 \%$ of those who had experienced physical violence reported that an incident had taken place within the last 12 months, and $4 \%$ of women disclosed that they had experienced sexual violence at least once. Current husbands, or partners, and former husbands, or partners, are the most likely to use physical violence (named by $90.9 \%$ of women). There is no profile of a "typical" survivor of domestic violence, since women in all demographic categories experience it. Girls who are underage when married are thought to be especially vulnerable to violence from their husbands or their families.

The Law on the Prevention of Domestic Violence and subsequent State Program for the Prevention of Domestic Violence for 2014-2023 led to a formal response program for domestic violence, expansion of legal protection for survivors, and dispelling the widespread notion that domestic violence is a private matter. Both state and civil societyrun facilities provide assistance to survivors of gender-based violence (GBV) through support and crisis centers that offer shelter as well as legal and psychological counseling.

Though more latent, human trafficking is another type of GBV. In 2013, the government assisted 17 human trafficking victims, while NGOs provided assistance to 67 more (48 victims of forced labor and 19 victims of trafficking for sexual exploitation). Women are vulnerable to trafficking especially, "after they are informally divorced from their absent migrant husbands and they need to provide for their families." Other factors that push women to fall victim to human trafficking include inequalities in the labor market, experiences of domestic violence and isolation, lack of social protection, and low educational qualifications.

\section{Access to Justice}

Women face specific barriers to justice, not only in cases of domestic violence, but for other human rights violations, largely due to their frequent lack of legal literacy. Early and polygamous marriages are prohibited under Tajik law, but they nevertheless take place through religious ceremonies. The official number of divorces increased 1.3 times from 2010-2013 (one in every 14 marriages ends in divorce), although the actual divorce rate is higher given the rise in men initiating them through repeating "talaq" (very often conveyed by migrant husbands via telephone or SMS text). For women in unregistered marriages, divorce initiated by "talaq" is sufficient grounds for eviction by in-laws, with no legal rights to claim child support or joint property, as customs do not accord women rights to immovable property. A detailed survey of 1,300 women and girls, conducted under an ADB pilot project in four districts of the Rasht Valley, revealed that $38 \%$ did not know the meaning of "joint marital property," and $62 \%$ believed that the religious practice of the husband pronouncing "talaq" three times constitutes a legal divorce. Another study carried out in Khatlon viloyat to examine women's property ownership found that $82 \%$ of divorced 
women did not receive any housing under the settlement, but instead returned to their parents' home or lived with relatives.

Judges have very limited experience applying either domestic or international legal norms in sex-based discrimination cases. While more than half of judges (57\%) have heard cases concerning violations of the rights and freedoms of women and girls, only $11.2 \%$ relied on the Law on State Guarantees of Equal Rights and Opportunities for Men and Women; by contrast, $19.6 \%$ used it in cases concerning protection of men's rights. Only $7 \%$ of judges applied the provisions of Convention on the Elimination of All Forms of Discrimination Against Women (CEDAW) (in cases involving women or men), and the majority of judges relied only on basic legislation, that is, the Family Code, Criminal Code, and Labor Code, which have limited discrimination provisions.

\section{Agriculture and Natural Resources}

Agricultural work is largely feminized in Tajikistan, with an estimated 75\% of working women employed in it. However, women's agricultural work is characterized by low pay and job insecurity, back-breaking conditions, lack of access to and control over productive resources, limited presence as managers, and low technical and specialized knowledge. While women headed 13\% of dekhan farms in 2014, the average size of women-headed farms is smaller than those headed by men. Furthermore, women managed only $6.4 \%$ of all planted crop lands on dekhan farms.

The country's water infrastructure, both for irrigation and drinking, has deteriorated since the Soviet period, which has resulted in a paradoxical situation: "many areas face water shortages for irrigation and personal consumption, but many rural people and agriculture suffer the effects of rising water table and increasing soil salinity." Women are the primary users of household water and spend less than 30 minutes per round trip to collect drinking water, but make four or five collection trips per day carrying containers by hand and travel several kilometers. A survey in Sughd viloyat revealed that most households source their water from irrigation canals, streams, or rivers, but they also use wells and springs, as well as collected rainwater. Rural women's participation in community-based water management is not proportionate to their burden of livelihood maintenance, the rising trend of femaleheaded households, or their direct interest in improving water provision. Despite many men being absent from rural areas because they have emigrated for work, they are overwhelmingly dominant in water users' associations (WUAs).

Despite gender inequalities in agriculture, women have great potential as agents of change. Rural women are quick to "grasp the holistic nature of farming and offer examples and solutions that they are already engaging in to adapt to climate change." Rural women can also be potential agents for climate change adaptation, as demonstrated by several strategic projects that have successfully involved them. One such project enabled rural women to start herb and vegetable seedlings in cold weather and extended the growing season. Women also learned about food preservation. 


\section{Education}

Gender inequality is still prevalent in education. Enrollment at primary school (grades 1-4) is very high for both sexes, and girls constitute $48 \%$ of all students. At the general secondary level (grades 10-11), 45\% of students are girls. However, women constitute only $29 \%$ of tertiary students. Access to education is one of the most critical issues for girls and young women today. Faced with the stark problem of girls' decreasing enrollment and completion rates, the government has prioritized gender parity within educational reform projects. National programs and strategies encourage girls to complete basic education, and provide scholarships for higher education. While such strategies recognize gender stereotypes and poor school conditions as obstacles to girls' education, several interrelated factors contribute to girls' school leaving and their absenteeism, but these have been comprehensively addressed.

Poverty is the most commonly cited reason for girls leaving school after grade 9; however, in-depth studies demonstrate that poverty combined with deeply ingrained gender inequalities is the key factor. Girls are generally expected to marry and join their husbands' families, with boys providing for their parents throughout their lives. Thus, the return on the household's investment in boys' education is seen as much greater than for girls, who are expected to contribute to their husband's family. Gender roles also influence school leaving, and demand for unpaid and low-paid agricultural labor and household work results in more girls than boys withdrawing from school. Early marriage for girls is linked to school leaving as some families keep them out of school in order to improve their prospects. Infrastructure problems also contribute to girls dropping out of school, particularly the lack of public transportation and suitable dormitories. Women's NGOs that work with parents, religious leaders, local authorities, and school administrators demonstrate that it is possible to work with individual families to promote girls' education. Such an approach should be scaled up and expanded through wider campaigns highlighting the value of female education.

Gender inequalities in secondary education are magnified in tertiary education, both in technical and vocational education and training, and in higher education. A consideration of all tertiary education combined reveals a bias in favor of male students, the converse of what is observed in other Central Asian countries. In 2011, for example, for every 100 men enrolled in higher education, there were only 41 women. Women who continue their education after compulsory schooling are most likely to pursue secondary vocational education. The proportion of women enrolled in primary vocational education has steadily decreased from $28 \%$ of all students in 2005 to the current rate of $18 \%$. Data about study subjects (for secondary vocational education only) show that the large majority of women study either health or education and are virtually unrepresented in subjects such as economics and management, construction, transport, agriculture, energy, metallurgy, and mechanical engineering. The absence of women from technical fields is particularly concerning in the context of ADB projects as it suggests that infrastructure investment will not directly boost women's employment opportunities. 
Girls with disabilities in particular have very limited opportunities for education. Families often prefer to keep girls with disabilities at home, either to educate them there or out of concern for their safety. Because they generally do not expect their daughters to work or marry, in contrast to boys with disabilities, they do not give priority to girls' education. As a result, women with disabilities have lower literacy rates and higher unemployment rates than men with disabilities. Efforts are needed to empower girls and women with disabilities to make their own decisions about the kind of training and employment they would like to pursue.

\section{Energy}

While energy poverty impacts the whole population, differences in access to resources ensures the impact on women and men is not the same. Household expenditures on gas (for cooking) and coal (for heating) are high, especially for rural households. As a result, the population relies heavily on supplementary fuels, which men are responsible for purchasing and women and children are responsible for collecting. Women spend considerable time collecting firewood, pressing dry dung, and preparing briquettes from coal dust, contributing considerably to the household budget through their labor. When energy resources are insufficient, daily domestic tasks are difficult. Women FGD participants described the various labor-saving electrical appliances they have in their homes, but reported that because of electrical outages, they frequently cannot use them. Insufficient heating and the use of unclean solid fuels for cooking contribute to health problems in women, children, and the elderly, who spend more time in the home.

Energy shortages also have a negative impact on businesses, especially small-sized and home-based enterprises. The types of businesses that women typically engage in, such as tailoring and sewing, and baking and food production, are associated with high electricity consumption. Women operating micro- and small-sized businesses may not have the capital to invest in generators, or even to pay high electricity tariffs. Women's entrepreneurship schemes should be linked to energy projects that could assist them to pay tariffs or to transition to more affordable or sustainable energy sources. It was reported that women are generally interested in efficiency and alternative sources of energy, but they are not always included in training programs, nor do they necessarily have the agency in the family to make decisions about adopting energy-saving technologies. As the population becomes exposed to new technologies, such as solar power, the need for local specialists will also increase, and there are potential opportunities for women if attention is given to attracting them to technical and vocational education and training in renewable energy.

\section{Entrepreneurship and Enterprise Development}

Developing the private sector and attracting investment are cornerstones of national strategies for poverty reduction and improving living standards. The Government of Tajikistan and the international community have taken several positive steps to support 
women's entrepreneurship. After the "one window" system was introduced in 2009, the total number of individual entrepreneurs registering with tax authorities increased and in 2011 , women represented $14.7 \%$ of sole proprietors overall. In the formal sector, women represented $21.3 \%$ of individual entrepreneurs operating on the basis of a patent (license) and $38.0 \%$ operating on the basis of a certificate from the tax authorities.

Support for women's entrepreneurship is a goal of the National Strategy for Enhancing the Role of Women in the Republic of Tajikistan for 2011-2020. Under this strategy, family-and home-based businesses receive particular attention with the goal of a more equitable distribution of labor, increased female agricultural employment, and retraining for unemployed women. Gender analysis in the area of small and medium-sized enterprise development is complicated by incomplete data about women and men working in business, either as owners or employees. There is also no consensus on what constitutes a "women's business" or "female entrepreneurship." Still, women's representation among registered owners of individual enterprises has increased. Female management of small, medium-and large-sized firms, however, is significantly less than in Eastern Europe and Central Asia combined. Women also represent roughly $20 \%$ of employees in the private sector.

Women's businesses tend not only to be smaller in size, but they are also concentrated in service-oriented, nonproduction sectors where large number of workers are not required, or individual women work in high-risk sectors, such as shuttle and market-based trade. Although female-led firms have fewer employees, they do tend to hire more women, but they also have lower annual turnover and profits than male-led firms. Expanding opportunities for women to enter nontraditional, and more lucrative, sectors should have a follow-on effect of also increasing female employment.

Male and female entrepreneurs face many common problems in terms of starting and running businesses, such as access to finance, unfavorable tax rates, poor infrastructure, political instability, and corruption. However, prevailing gender norms are also responsible for women's lower representation in business, and there are no special measures to offset the barriers that women face. Women experience greater bureaucratic obstacles in registering a business than men, are more likely to cite taxation as particularly onerous and, in some cases, report discrimination and harassment by tax authorities. Female entrepreneurs are also disadvantaged by their unequal access to human and social assets, such as business networks, specialized knowledge and skills, and even business-related information.

Despite loan requirements being gender neutral, in reality, women have more limited access to credit due to their lack of collateral, lack of business experience, high interest rates, and personal aversion to taking on risk. According to data from the Association of Microfinance Organizations of Tajikistan, on average around a quarter of microfinance loans and just under a third of bank loans were issued to women in 2014; additionally, the amount of credit that women received was less than what men received. Because women are less likely to have ownership rights to the kind of property that can serve as collateral, and they are deterred by interest rates that are too high for them to repay, women tend to borrow money from relatives or friends or to rely on remittances. Microfinance has also been an attractive option for women because of the less stringent collateral requirements 
and the possibility of group loans. However, there appears to be a decreasing number of female microcredit borrowers in recent years.

Gender stereotypes and how society perceives female entrepreneurs, and indeed how they perceive their own capacities, have a considerable impact on women's success in business. Despite the growing number of female entrepreneurs, business is still widely perceived as a male occupation, especially running medium- and large-sized enterprises. Female entrepreneurs attach much greater value than males to family support because it is essential to whether a woman will start a business, for the general operation of the business, and for making decisions on new investments. Established female entrepreneurs who participated in this assessment also noted the value of receiving public recognition from a national organization, such as the National Association of Business Women of Tajikistan.

There are many initiatives in Tajikistan to empower women economically; most focus on increasing women's entrepreneurial activities through business training and, in some cases, small grants. The most effective initiatives combine basic business training with comprehensive assistance in developing business plans, followed by grants or credit lines that enable them to launch a business. Sustained support in the form of specialized training and information on marketing, legislation, taxation, regulations, and social fund payments, as well as mentoring, business incubators, small business support centers, and concessional loans, were also mentioned as aids for women growing their businesses.

\section{Transport}

During consultations for this assessment, women voiced clear priorities and concerns about road rehabilitation and construction projects. Because they are less likely to be in full-time formal employment than men, women's travel tends to be more varied and connected to household responsibilities. Women frequently travel with children, and they go to healthcare facilities, to schools, to visit relatives, and sometimes to local government offices, and also in connection with work in petty trade and markets. The lack of road infrastructure limits women's mobility, but more significantly, the lack of reliable, secure, and affordable transport options means that they of ten cannot travel more than short distances and only during daylight hours. Future transport projects should address the factors that inhibit female mobility, for example, by increasing safety features, such as priority seats for women (especially for women with children), employing more female staff (especially for long-distance travel), constructing bus stations and waiting areas that are safe for women, and promoting public confidence in new transport options.

Although the rehabilitation of large national highways has been a priority in Tajikistan, women highlighted both the need to improve small feeder roads between villages and safety issues associated with both the old and new roads. Ensuring safety on and near roads, especially with regard to children, is of paramount importance to women, and they prioritize introducing clear road signs, sidewalks, barriers between roads and sidewalks, pedestrian crosswalks, and traffic lights. Because women are largely absent from transport 
decision-making positions, measures should be taken to ensure that their priorities are considered whenever road and transport projects are developed.

Improved roads and the creation of roadside infrastructure have the potential to provide women with employment and income-generating activities. At present, however, women are not well represented as either transport employees or business owners. Further, to ensure that women's enterprises benefit from improved transport links, roadside infrastructure must be created that meets their accessibility, safety, rental cost, and hygiene needs. Attention should also be given to ensuring that road improvements do not unintentionally increase women's uncompensated workload, such as in agricultural work or gathering fuel and water. 



\section{Background and Context}

Tajikistan is a landlocked, mountainous country that borders two other former Soviet republics, that is, the Kyrgyz Republic and Uzbekistan, along with Afghanistan and the People's Republic of China. While Tajikistan is largely identified with its recent Soviet past, the present territory has been home to civilizations dating back to the Neolithic and Bronze ages. The Tajik nation traces its origins to the Samanid Empire (819-999 AD), the last Persian dynasty to rule Central Asia, and the language of contemporary Tajikistan is a dialect of Farsi, different from the Turkic languages spoken in the neighboring Central Asian countries. The influences of the country's many conquerors, including Alexander the Great, Genghis Khan, and Tamerlane, and the trade that operated along the Silk Route, have all contributed to the rich culture of present-day Tajikistan.

Tajikistan's population is 8.4 million, with almost three-quarters of the country living in rural areas.' According to 2010 census data, $84.3 \%$ of the population is of Tajik ethnicity, followed by $12.2 \%$ of Uzbek ethnicity, and other groups, such as Russians, Kyrgyz, and Turkmen, each making up less than $1 \% .{ }^{2}$ It should be noted that estimates of the Uzbek population living in Tajikistan can vary depending on how mixed Tajik-Uzbek families, who mainly live in border areas, are counted. ${ }^{3}$ Tajikistan is also home to the Pamiri people, who live in the Gorno-Badakhshan Autonomous Region. They are considered ethnically Tajik, but have distinct languages and culture and have ties with Pamiris in Afghanistan, Pakistan, and the People's Republic of China. Over $90 \%$ of the population identifies as Muslim, and most people are Sunni Muslims, though the Badakhshan region is home to a minority Ismaili Shia population (approximately 4\%). ${ }^{4}$

\section{A. Gender Equality in the Post-Soviet Period}

In 1991, when Tajikistan declared independence from the former Soviet Union, it was one of the least developed and poorest of the Soviet republics. Like other Soviet republics, Tajikistan inherited an ideology and legal framework that supported equal rights for women and men. Soviet authorities recognized the need to expand women's roles in economic, political, and social life, and in Central Asia this meant abolishing restrictions on women's rights, redistributing domestic chores, mobilizing a female workforce, and requiring girls to attend school. The Soviets directly addressed traditions that were seen to disadvantage females. Arranged and polygamous marriages were prohibited and un-veiling was promoted through mass campaigns. The Soviets viewed Central Asian traditional kinship and family structures as antithetical to their values and saw the mobilization of women as a means to construct a

\footnotetext{
Agency for Statistics under the President of Tajikistan (State Statistics Agency). 2014. Tajikistan in Figures. Dushanbe. pp. 19, 26

2 State Statistics Agency. 2012. National composition, language and citizenship of the population of the Republic of Tajikistan. Volume III, Population and Housing Census of Tajikistan 2010. Dushanbe. p. 7. [Russian version].

See Central Intelligence Agency. The World Factbook. https://www.cia.gov/library/publications/the-world-factbook/geos/ti.html

4 US Department of State. 2013. Human Rights and Labor. International Religious Freedom Report for 2013. Washington, DC. http://www. state.gov/j/drl/rls/irf/religiousfreedom/index.htm?year=2013\&dlid=222343
} 
new social order. Through the work of women's departments, "traditional culture was either destroyed or rendered invisible, confined to the most intimate and private sphere, whereas in the public arena new identities were created and society was secularized." 5

Several indicators suggest that the Soviet approach did emancipate women in Tajikistan, who enjoyed formal equal rights, high levels of education, labor force and political participation, and access to healthcare comparable to that of women in developed countries, as well as affordable childcare. ${ }^{6}$ At that time, the female labor force participation rate was $74 \%,{ }^{7}$ as compared to the current one of $45 \% .{ }^{8}$ At the same time, however, women experienced the double burden of having to fulfill labor quotas while also attending to family and domestic responsibilities. Indeed, in Central Asia, "the double burden was more onerous owing to the prevalence of large families, relatively low provisions of communal amenities such as crèches, canteens, and laundries, and outside the main cities, the chronic scarcity of laborsaving devices such as washing machines and vacuum cleaners." It should also be noted that while Soviet policy focused on developing women's public roles, it had no parallel ideology to encourage men to take on greater domestic responsibilities.

It has been argued that in Tajikistan the Soviet approach to women's emancipation was not as effective as in other countries, and traditional patriarchal patterns of family and social life remained quite strong. "The entry of women into public life, sponsored and encouraged by Soviet authorities, has weakened patriarchy to a substantial extent, but the socialization of women, especially in rural areas of Tajikistan, remains centered on the patrilineal family and focuses on childrearing, limiting their mobility and access to employment and education." In fact, a survey conducted in 1988 showed that for the labor force participation rate, fertility rates, and the number of females in higher education, women in Tajikistan had not achieved the same level of freedom as women in the former Soviet Union as a whole.11

In the early transition years, Tajikistan faced challenges of adopting new economic and social models and developing a national identity, which included re-evaluating old gender arrangements. Under the 1992 coalition government, "pressure was put on urban girls and women to abandon their European clothes in favor of native costumes, or in other words to 'de-sovietize' themselves. This...was experienced by many as incipient Islamization and as the first step towards the reestablishment of pre-Soviet gender identities." 12 Scholars suggest that women in Central Asia have found themselves caught between competing impulses: a desire to "return to their 'authentic' roots," but also an unwillingness to wholly reject the Soviet ideology and a wish, "to continue along the road to greater personal independence and freedom of choice."13

5 A. Ishkanian. 2003. Gendered Transitions: The Impact of the Post-Soviet Transition on Women in Central Asia and the Caucasus. Perspectives on Global Development and Technology. 2 (3-4). pp. 481-482.

6 Ibid. p. 480

7 UNICEF. 1999. Women in Transition Period, Regional Monitoring Report \#6, Florence: UNICEF Innocenti Research Centre. p. 26. http://www.unicef-irc.org/publications/pdf/chapt-2_rus.pdf (Accessed November 2015)

8 State Statistics Agency. 2012. Women and Men of the Republic of Tajikistan. Dushanbe. p. 90. [Russian version]

9 Gendered Transitions: The Impact of the Post-Soviet Transition on Women in Central Asia and the Caucasus, p. 482.

10 K. Nourzhanov. 2013. Tajikistan: A Political and Social History. Canberra: Australian National University Press. p. 83.

11 Ibid.

12 Gendered Transitions: The Impact of the Post-Soviet Transition on Women in Central Asia and the Caucasus, p. 486

13 Ibid. p. 486-487. 
The early post-Soviet period coincided with a devastating civil war that erupted in 1992 and continued for five years. The conflict began with demonstrations over contested presidential elections and escalated to armed fighting between supporters of the ruling national government and a loose coalition of opposition groups that included reformers and Islamists. The opposing factions were also divided along regional and ethnic lines.

The immediate impact of the conflict was significant in terms of human losses (the deaths of $1 \%$ of the population, 25,000 women widowed, 55,000 children orphaned, and almost one million people displaced), economic losses ( $\$ 7$ billion), and the disintegration of the social infrastructure. ${ }^{14}$ During the civil war, thousands of men were murdered or disappeared, but women were also specifically targeted by the Tajik conflict factions. Forced marriages and human trafficking-mainly of young girls-became more acceptable during the war. ${ }^{15}$ There is evidence that rapes and sexual violence were perpetrated during the civil war, but the subject remains taboo, the number of survivors is unknown, and such crimes have not been investigated. ${ }^{16}$ The civil war deeply impacted gender relations, causing the gap to widen, "in all spheres of life-economic, political, cultural, family." 17

Many respondents to the present assessment cited the impact of traumas that originally dated to the civil war and that continue to affect women and girls today. For example, immediately after the conflict, marriages of underage girls increased, mainly due to economic deprivations and fears for their safety. ${ }^{18}$ Indeed, a lingering "fear of abduction and rape, particularly of girls and young women, is strong enough to affect their freedom of movement." 19 Several respondents noted that the girls who were married following the civil war abandoned their schooling and today form a generation of women who both have less education than their mothers and who are repeating the cycle with their own daughters. The impoverishment of the population once the ceasefire was declared has been linked to an increase in violence against women, especially domestic violence, as well as the exploitation of women in narcotics trafficking and prostitution. ${ }^{20}$

In the aftermath of the war, many women found themselves without male relatives, the traditional protectors and breadwinners, and were "forced to take up the burden of keeping their households going. Women started searching for additional sources of income since their husbands were either in armed groups or refugees, or had no opportunity to move about freely because of the ongoing armed conflict. Women began to do jobs that were traditionally classified as male in Tajikistan." 21 The topic of women's changing gender roles is discussed in more detail in a subsequent section, but it is important to note that many women took on male roles, not due to choice or emancipation, but out of necessity.

Women were marginalized in the formal peace process (there was only one woman on the National Reconciliation Committee), but the presence of a large number of international

14 A. Kuvatova. 2001. Gender Issues in Tajikistan: Consequences and Impact of the Civil War. Hommes Armés - Femmes Aguerries, 127-136. Geneva: Graduate Institute of Development Studies. p. 128. http://graduateinstitute.ch/files/live/sites/iheid/files/sites/genre/ shared/Genre_docs/2888_Actes2001/11-kuvatova.pdf

15 Integrated Regional Information Networks (IRIN). 2004. Tajikistan: Civil war has left one in three women victims of domestic violence. Our Bodies - Their Battle Ground: Gender-based Violence in Conflict Zones. p. 25. http://www.irinnews.org/pdf/in-depth/gbvirin-in-depth.pdf.

16 Amnesty International. 2009. Violence is Not Just a Family Affair. Women Face Abuse in Tajikistan. London. pp. 19-20.

17 Gender Issues in Tajikistan: Consequences and Impact of the Civil War, p. 128.

18 In some regions, girls as young as 13 were married. See, e.g., N. Yavari d'Hellencourt. 2007. Qualitative Survey on Issues in Girls' Education in Tajikistan: An in-Depth Analysis of the Reasons Girls Drop Out of School. Dushanbe: Ministry of Education/UNICEF. p. 9.

19 Gendered Transitions: The Impact of the Post-Soviet Transition on Women in Central Asia and the Caucasus, p. 485.

20 Gender Issues in Tajikistan: Consequences and Impact of the Civil War, pp. 130-131.

21 Ibid. p. 130 
organizations in peace negotiations and the distribution of humanitarian aid arguably brought about opportunities to develop gender policy earlier than in neighboring Central Asian countries. After the signing of the General Peace Accord in 1997, "the process of introducing international standards in political, economic, and social reforms became more active, particularly the introduction of international legal norms."22 From 1998 onward, the government passed several policies to enhance the role of women.

\section{B. Measures of Gender Equality}

Tajikistan ranks 75th out of 149 countries in the United Nations Development Programme's (UNDP) 2013 Gender Inequality Index (GII). ${ }^{23}$ The Gll measures the extent to which national development is eroded by gender inequality, and is based on five indicators in the areas of reproductive health, the labor market, and empowerment. ${ }^{24}$ The 0.383 value for Tajikistan represents a 38\% loss in achievement due to gender inequality, as compared to the regional average for Europe and Central Asia of 32\%. ${ }^{25}$ A comparison of Gll values and key regional indicators indicates that Tajikistan shares many challenges with other Central Asian countries, but it also fares poorly in female education (especially given the near-universal adult literacy characteristic of the Soviet period) and adolescent birth rates.

Table 1: Tajikistan's Gender Inequality Index for 2013 relative to Central Asian Countries ${ }^{a}$

\begin{tabular}{|c|c|c|c|c|c|c|}
\hline & $\begin{array}{c}2013 \\
\text { GII } \\
\text { Value }\end{array}$ & $\begin{array}{c}\text { Maternal } \\
\text { mortality } \\
\text { ratio }\end{array}$ & $\begin{array}{l}\text { Adolescent } \\
\text { birth } \\
\text { rate }\end{array}$ & $\begin{array}{c}\text { Female } \\
\text { seats in } \\
\text { parliament } \\
(\%)\end{array}$ & $\begin{array}{c}\text { Female } \\
\text { population } \\
\text { with at least } \\
\text { some } \\
\text { secondary } \\
\text { education } \\
(\%)\end{array}$ & $\begin{array}{c}\text { Female } \\
\text { labor force } \\
\text { participa- } \\
\text { tion rate }(\%)\end{array}$ \\
\hline Kazakhstan & 0.323 & 51 & 29.9 & 18.2 & 99.3 & 67.5 \\
\hline Kyrgyz Republic & 0.348 & 71 & 29.3 & 23.3 & 94.5 & 55.7 \\
\hline Tajikistan & 0.383 & 65 & 42.8 & 17.5 & 89.9 & 58.7 \\
\hline Turkmenistan & no data & 67 & 18.0 & 16.8 & no data & 46.7 \\
\hline Uzbekistan & no data & 28 & 38.8 & 19.2 & no data & 47.9 \\
\hline
\end{tabular}

a Note that definitions of key indicators can be found in Table 4, Statistical Annex, UNDP Human Development Report 2014. GII = Gender Inequality Index.

Source: UNDP. 2014. Human Development Report 2014, Sustaining Human Progress: Reducing Vulnerabilities and Building Resilience. New York.

Since the Gll was introduced, ${ }^{26}$ Tajikistan's values have worsened slightly (in 2011 the value was 0.347$).{ }^{27}$

22 A. Dar. 2013. The Role of NGOs in Independent Tajikistan. The International Journal of Not-for-Profit Law. 15(1). http://www.icnl.org/ research/journal/vol15iss1/art_3.htm\#_ftn1

23 UNDP. 2014. Human Development Report 2014-Sustaining Human Progress: Reducing Vulnerabilities and Building Resilience. New York. Statistical Annex, Table 4.

24 UNDP introduced the GII in 2010, replacing earlier measures, the Gender-related Development Index (GDI) and the Gender Empowerment Measure (GEM), which means that values and rankings for Tajikistan from before 2011 are not directly comparable to 2013 values.

25 Under the GII index, zero indicates that men and women fare equally and there are no losses due to inequality. A value of 1.00 signifies that women fare as poorly as possible in all measured dimensions.

26 UNDP introduced the GII in 2010, replacing earlier measures, the Gender-related Development Index (GDI) and the Gender Empowerment Measure (GEM), which means that values and rankings for Tajikistan from before 2011 are not directly comparable to 2013 values.

27 UNDP. 2011. Human Development Report 2011- Sustainability and Equity: A Better Future for All. New York. Statistical Annex, Table 4. 
The World Economic Forum uses the Global Gender Gap Index to measure the magnitude and scope of gender-based disparities in the areas of economic participation and opportunity, educational attainment, health and survival, and political empowerment. In 2014, Tajikistan received a score of 0.665 , indicating limited progress since 2007 , when the country scored $0.658 .{ }^{28}$ While its scores for educational attainment and for health and survival are high, scores for both economic participation and opportunity (labor force participation, wage equality, and the numbers of senior, professional, and technical workers) and political empowerment (women in parliament and ministerial positions) are low, and offset the other positive indicators of equality.

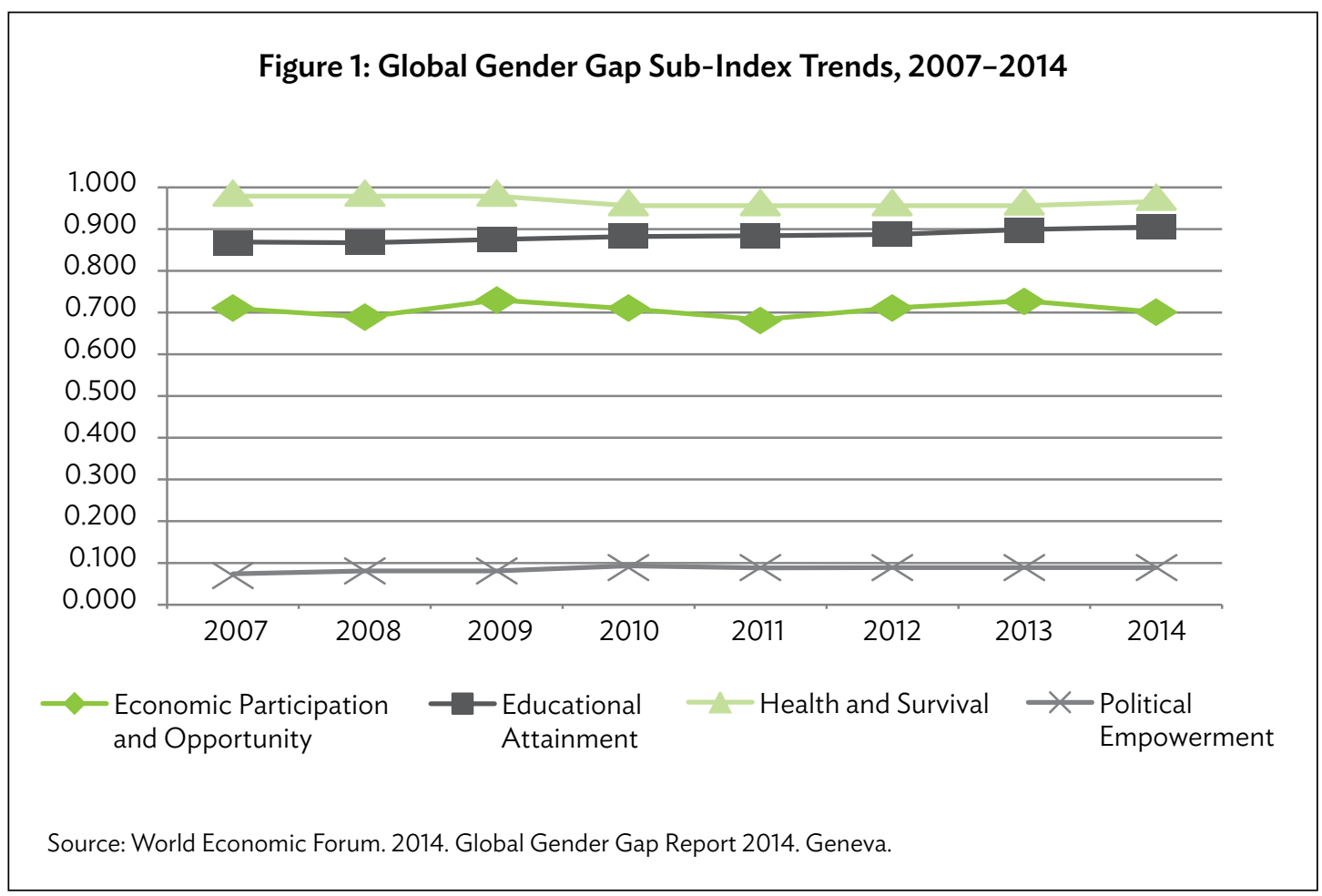

In contrast to the inequality indices already mentioned, the Social Institutions and Gender Index (SIGI) of the Organization for Economic Co-operation and Development (OECD) examines the root causes behind such inequalities. The SIGI examines 12 indicators in five categories: family code, physical integrity, son preference, civil liberties, and ownership rights. Tajikistan's SIGI value for 2014 is 0.139 , corresponding to a medium level of gender discrimination in the fields measured. ${ }^{29}$

Scores by sub-index suggest that women in Tajikistan have few legal restrictions on their ability to access and control economic and natural resources and assets. ${ }^{30}$ On the other hand, the SIGI scores Tajikistan "very high" in terms of son bias, which is a measure of

28 Countries are scored on a scale in which 1.00 is the highest (full equality) and zero the lowest. World Economic Forum, Global Gender Gap Index 2014. Geneva.

29 Countries are given discrete scores ranging from 0 (a low level of discrimination) to 1 (a high level of discrimination)

30 Social Institutions and Gender Index, Tajikistan. http://genderindex.org/country/tajikistan. Accessed December 2014. 
"unequal intra-household investments in the care, nurture and resources allocated to daughters and sons." ${ }^{31}$ This indicator attempts to capture formal and informal laws and also the social norms and practices that underlie the unequal treatment and "economic undervaluation of women and girls." 32 These particular indicators correspond to an observation shared by the vast majority of respondents to this assessment: that the legal and policy framework supporting equality is solid in Tajikistan, but that women and girls face many restrictions and few opportunities to realize themselves in the family.

\section{Figure 2: Tajikistan's Performance in the Social Institutions and Gender Index 2014 Sub-Indices}

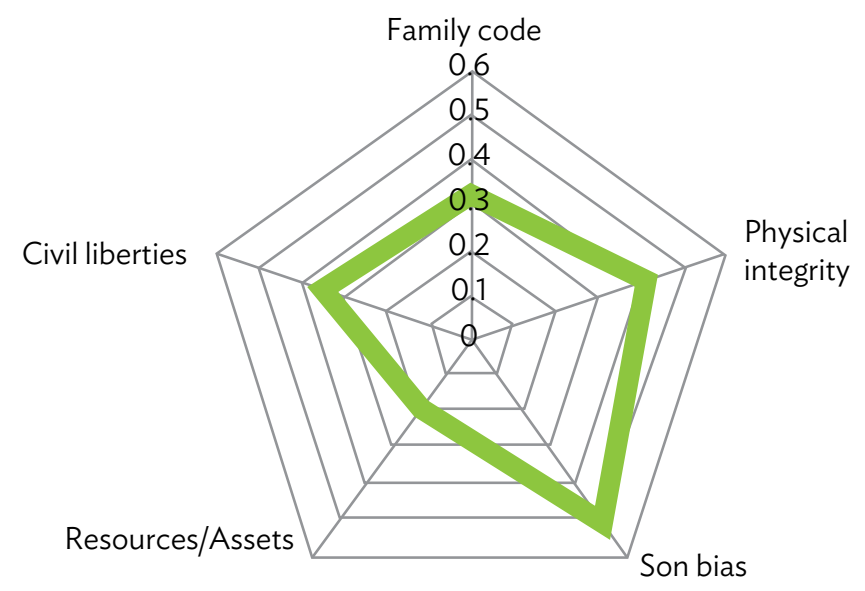

Source: Organization for Economic Co-operation and Development. 2014. SIGI: Tajikistan. http://genderindex.org/ country/tajikistan.

Evaluating where disparities between women and men persist and renewing commitments on gender and development is one of the focus of government in 2016. Tajikistan's most recent national review of progress toward the Millennium Development Goals (MDGs), specifically Goal 3 on gender equality and women's empowerment, identifies weaknesses in several areas: girls' lack of educational opportunities, the need to provide rural women with equal access to economic resources, women's limited participation in governance, and weak protections against gender-based violence (GBV). ${ }^{33}$ The National Development Strategy for Tajikistan (discussed in more detail in the following section) is aligned with the MDGs, with a series of national consultations having been organized in 2013 to assess, "the aspirations and perspectives of a range of stakeholders on the Tajikistan they want to see beyond 2015." 34 Gender inequality was identified as "one of the most pervasive forms of inequality in Tajikistan's society and economy," 35 and stakeholders made recommendations for the post-2015 development agenda that included the following: more intensive

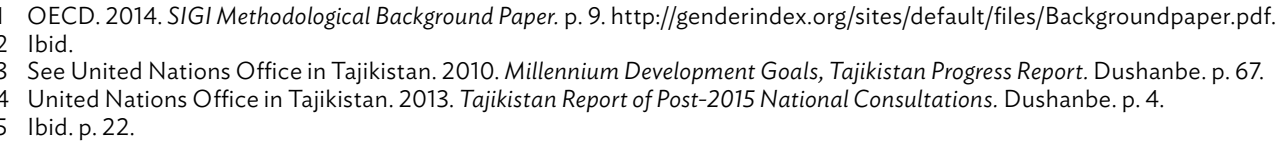


advocacy to eliminate stereotypes, more effective mainstreaming and monitoring of state programs, and public-private support for women's entrepreneurship. ${ }^{36}$ An online survey conducted during the consultation process allowed the general public to voice an opinion on which MDGs should remain priorities after 2015 . Of 558 respondents, 62 or $11 \%$ voted for "gender equality," but when this category is combined with the votes for "improve maternal health" and "ensure secondary education for all" (which arguably has a gender component), 39.5\% chose goals that are especially relevant to women and girls. ${ }^{37}$ These consultations, like those conducted for the present assessment, suggest that there is a need to improve gender equality in Tajikistan.

\section{National Legal and Institutional Framework}

In the last decade, the official gender equality framework has been expanded and strengthened through the adoption of new laws, amendment of existing laws, development of national programs, and incorporation of objectives within general policy documents. For the most part, however, such developments have focused on raising the status of women and girls and eliminating barriers to the realization of their rights, rather than on equalizing responsibilities and opportunities for women and men or addressing gender stereotypes.

\section{Laws and Policies on Gender Equality}

The Constitution of the Republic of Tajikistan recognizes international law as a component part of the national legal system, ${ }^{38}$ and Tajikistan is a State Party to the Convention on the Elimination of All Forms of Discrimination Against Women (CEDAW) and to other fundamental human rights treaties..$^{39}$ In 2014, the parliament ratified the Optional Protocol to CEDAW, which allows individual women in Tajikistan to submit complaints to the CEDAW Committee and gives them an additional remedy for violations of the convention. ${ }^{40}$ Important steps have also been taken to implement UN Security Council resolutions on women, peace, and security (1325 and 2122) with the drafting of a national action plan.

The Constitution guarantees equal rights on the basis of sex (Article 17), and principles of nondiscrimination are enshrined in basic legislation, for example, the Family Code, the Labor Code, the Land Code, the Criminal Code, the Law on Education, and the Law on Public Health. While there are no laws that directly restrict women's rights, additional guarantees that aim to "protect" women, such as the Labor Code's night work prohibition, have nonetheless kept women from being employed in male-dominated industries.

In 2005, Tajikistan adopted the Law on State Guarantees of Equal Rights and Opportunities for Men and Women, which is the only law to define the concepts of gender 
and sex-based discrimination. The law prohibits discrimination on the basis of sex, while distinguishing special measures to protect pregnancy and the health of women and men, and it guarantees equal rights in public authorities, civil service, education, labor, and the family. The equal rights law is largely declarative, meaning that it has no provisions about how "guarantees of equality are to be provided and how to respond to cases of discrimination"; ${ }^{41}$ it does not outline clear remedies for violations. Gender experts note that the effectiveness of the law is also hampered by its failure to address indirect and hidden discrimination. ${ }^{42} \mathrm{~A}$ more comprehensive approach would be to expand the equal rights definitions to cover gender identity and pregnancy and to prohibit discrimination in areas of public law including, but not limited to: employment, vocational training, social security, the rights of the child, and access to justice..$^{43}$

Other legislative reforms are aimed at greater protection of women's rights, for example, laws combating human trafficking (2008), and domestic violence (2013), and protection of breastfeeding (2006). In 2010, the Family Code was amended to raise the legal marital age to 18 (for both women and men), which brought it in line with CEDAW.

Despite laws promoting gender equality, "legal gender differences" remain in those that result in unequal economic opportunities for men and women, including prohibitions for women from working in "hazardous" industries such as construction, mining, and metalwork, as well as differences in retirement ages -58 for women and 63 for men. ${ }^{44}$

Since 2006, Tajikistan has adopted several policy documents, national programs, and strategies that support gender equality goals. Some were intended to implement specific laws, for instance the Comprehensive Program to Combat Trafficking in Persons for 2006-2010, and the State Program for the Prevention of Domestic Violence for 20142023. Others addressed areas where there are clear gendered opportunity disparities, for example, the establishment of two presidential grant programs, one benefiting female entrepreneurs and another encouraging girls to pursue higher education. The State Program for the Education, Selection and Placement of Capable Women and Girls in Leadership Positions for 2007-2016 (adopted in 2006) aims to mitigate the barriers that prevent women from entering senior management.

In 2001, the government adopted an equal rights program that de-emphasized focusing solely on raising the status of women in favor of a policy based on changing social relations between women and men. The program expired in 2010, and civil society organization (CSO) monitoring of its implementation found that, despite government, NGO, and international organization efforts, many goals were not realized; in fact, a negative trend was exhibited in some gender indicators. ${ }^{45}$ Several major obstacles to achieving gender equality were singled out, including the persistence of rigid social norms about male and

41 Sh. A. Juraeva and Kh. E. Kast. 2011. Tajikistan: Country Monitoring Report 2010. Democratic Ownership and Development Effectiveness: Civil Society Perspectives on Progress Since Paris. Quezon City: The Reality of Aid. p. 224.

42 The Coalition of Public Associations "From de Jure Equality to de Facto Equality." 2012. The Second Shadow Report on the Realization of the Convention on the Elimination of All Forms of Discrimination against Women by Public Organizations of Tajikistan. Dushanbe. p. 9. 43 Ibid.

44 The World Bank. 2015. Women, Business and the Law 2016: Getting to Equal. Washington, DC.

45 The Coalition of Public Associations "From de Jure Equality to de Facto Equality." 2009. The State Program Basic Directions of State Policy to Ensure Equal Rights and Opportunities for Men and Women in the Republic of Tajikistan for 2001-2010: Progress Evaluation Based on Public Monitoring Results. Dushanbe. p. 76. 
female behavior, an inadequate legal base for the equal rights law, and a weak institutional mechanism to advance gender policy.

The successor stand-alone policy, adopted in 2010, is the National Strategy on Enhancing the Role of Women in the Republic of Tajikistan for 2011-2020.The strategy recognizes a lack of public gender equality understanding and gender policy support, the role of stereotypes, and the need to implement the formal equality that exists, but it nevertheless covers areas in which women encounter barriers: political participation, the labor market, entrepreneurship, and education. The strategy lists concrete actions for each sector, but does not establish the responsible agencies, a timeframe with milestones, sources of funding, or a monitoring plan.

The government has made significant progress in mainstreaming gender into national socioeconomic development strategies, beginning with the adoption of the Poverty Reduction Strategies for the Republic of Tajikistan for 2007-2009 and 2010-2012.These strategies and the current Living Standards Improvement Strategy for 2013-2015 and National Development Strategy for 2015 all dedicate chapters to gender equality as a component of developing the country's human potential. Inclusion of gender equality targets in these strategic documents ensures that indicators, implementing agencies, and financing are also delineated. Although the Living Standards Improvement Strategy anticipates that only about $21 \%$ of the estimated total funding for gender equality will be covered by the national budget (and about $40 \%$ to be covered by development partners), the government has contributed substantially more than it did under the Poverty Reduction Strategies for the Republic of Tajikistan for 2010-2012. Under the Living Standards Improvement Strategy, the state dedicated approximately $\$ 600,000$ to gender equality in comparison to $\$ 11,000$ under the previous Poverty Reduction Strategy.

Despite a solid legal and policy framework for protecting the rights of women and, to a lesser extent, advancing gender equality, many planned measures are never realized due to insufficient implementation mechanisms, weak monitoring and evaluation, and lack of dedicated finances. ${ }^{46}$ The reliance on donors and development partners to support initiatives is not optimal due to their internal funding limitations. Furthermore, the government has not sufficiently used gender methodologies within the larger budgetary reform process that would allow for more effective funding.

\section{National Mechanisms}

The Committee for Women's and Family Affairs (the Women's Committee) was established in 1991, and its authority was increased in 2006, making it the central authority carrying out state policy on protecting women's interests and rights. The Women's Committee has a broad mandate that includes cultivating women's rights, addressing women's socioeconomic participation, and delivering public services. ${ }^{47}$ The committee consists of a central office in Dushanbe with parallel provincial offices, as well as at the district and municipal levels. Each jamoat also has a council head or secretary who

46 The Second Shadow Report on the Realization of the Convention on the Elimination of All Forms of Discrimination against Women by Public Organizations of Tajikistan, p. 8.

47 Approved by Government Decision No. 608, 9 December 2006. 
is responsible for working with women. The Women's Committee operates regional information-consultation and crisis centers throughout the country (110 in total) and funded locally. The Chair of the Women's Committee is a government appointee, with 22 central office staff as of 2014. Women's Committee activities are diverse, ranging from research to considering citizen complaints, promoting women's rights through the media, monitoring international standard compliance, coordinating government and nongovernment gender equality activities, and training.

The Women's Committee work plan, which supports the branch offices, covers, among other items, climate change, support for labor migrants' wives, and peace and security issues. The current draft work plan has no dedicated finances, and it is anticipated that international development partners will support and collaborate on specific projects.

In the last seven years, the Women's Committee budget increased almost eight-fold from about TJS230,000 in 2007 to over TJS1.7 million in 2013. ${ }^{48}$ Still, in its most recent concluding observations, the CEDAW Committee noted that, despite government efforts to strengthen the Committee's structural and financial capacity, only a "very low percentage of the national budget [0.7\%] is allocated to it." ${ }^{\text {"9 }}$ The CEDAW Committee also raised issues over the Committee's status and visibility as the national mechanism for the advancement of women and called upon the state to further strengthen its mandate and provide it with adequate human and financial resources. ${ }^{50}$ Gender experts consulted for this assessment recalled the Committee's limited capacity to advocate for reform and effectively coordinate and monitor national policy.

In 2008, the government entered into a tripartite agreement with the Women's Committee and the United Nations Entity for Gender Equality and the Empowerment of Women (at the time, UNIFEM) to establish a mainstreaming network for the activities of seven ministries and agencies. ${ }^{51}$ Later, a coalition of women's NGOs acceded to the agreement. There are 25 network individuals whose main functions are to develop and monitor gender indicators, train staff in gender sensitivity, and formulate and implement public programs. Despite the network's creation, gender mainstreaming remains, "poorly embedded" in ministerial work. ${ }^{52}$ Network members are not adequately supported for the tasks required of them; they "carry out their duties on a voluntary basis and work on integrating gender approaches is considered an additional burden to their core functions." ${ }^{33}$ As a result, most network activities have consisted of internal awareness raising, and the ministries are virtually uninvolved in developing gender-sensitive strategies or analyzing extant ones. ${ }^{54}$

48 See Government of Tajikistan. 2012. Consideration of reports submitted by States parties under article 18 of the Convention on the Elimination of All Forms of Discrimination against Women, Combined fourth and fifth periodic reports. CEDAW/C/TJK/4-5. para. 50 (for the budget of the Women's Committee from 2007-2010); and Government of Tajikistan. 2014. National Review of the Republic of Tajikistan to Implement the Beijing Declaration and Platform for Action. p. 36 (for the budget from 2011-2013).

49 Committee on the Elimination of Discrimination against Women. 2013. Concluding observations on the combined fourth and fifth periodic reports of Tajikistan. CEDAW/C/TJK/CO/4-5 (56th Session, Geneva, 2013). para. 11.

50 lbid. para 12.

51 The government parties to the agreement are: the Ministry of Agriculture; the Ministry of Land Reclamation and Water Resources; the State Committee for Statistics; the Agency for Land Management, Geodesy and Cartography; Agroinvest Bank; the National Association of Dekhan Farms; and the Institute for Upgrading Civil Servants Skills. The State Program Basic Directions of State Policy to Ensure Equal Rights and Opportunities for Men and Women in the Republic of Tajikistan for 2001-2010: Progress Evaluation Based on Public Monitoring Results, p. 9.

52 Ibid.p. 11.

53 Ibid.

54 The Second Shadow Report on the Realization of the Convention on the Elimination of All Forms of Discrimination against Women by Public Organizations of Tajikistan, p. 17. 
Furthermore, the network does not comprise all line ministries or state agencies, and there is limited understanding of what constitutes a transformative gender policy or how to enact the national plans in government offices. While "almost all ministries and agencies" support the goals of advancing women and ensuring equal rights, "unanimous support of gender equality is not evinced in concrete actions and measures directed on restoring gender equity, in particular, when it comes to redistribution of powers of men and women both in [the] public sphere and in [the] family." 55

Though the government established the Office of the Commissioner for Human Rights (the ombudsman) in 2008, the ability of this office to serve the national machinery on gender equality is limited. While the ombudsman plays a role in protecting women's rights, its approach is not from the perspective of promoting gender equality, but from its strategic priority to protect "particularly vulnerable groups," a category that also includes children and persons with disabilities. ${ }^{56}$ Its most recent annual report dedicates a section to gender equality, but the focus is primarily on domestic violence, and data about complaints are not sex-disaggregated.

Another gender mainstreaming element to consider is local accommodation of nationallevel policies, programs, and strategies. The commitments included in the programs and strategies described in the preceding subsection are to be realized primarily by the Women's Committee, national government, and international organizations; few explicit actions are delegated locally. ${ }^{57}$ Gender assessments conducted in specific regions indicate that local gender action plans (GAPs) largely delegate their implementation to women's affairs departments, and activities are limited to social and cultural events, such as dance and poetry performances and celebrations of Women's Day or Navruz. ${ }^{8}$ It is not clear to what extent gender network ministries and agencies have transferred knowledge to their local counterparts.

Seven FGD participants that were heads of jamoat women's councils characterized much of their responsibilities as working with families on issues such as girls' education and divorce. Part of the job entails organizing material assistance for poor families, collecting statistical data, and assisting with local festivals. Based on the FGD discussions, these particular offices all had collaborative relationships with local women's NGOs. One study found that most district-level units have only one or two staff members, and lack financial resources and access to information (e.g., limited or no internet access), as well as linkages to their jamoat and district counterparts. ${ }^{59} \mathrm{~A}$ study in Rasht valley found that "because of limited resources and accessibility to remote areas, occasional meetings with women/ young girls are held at the village/jamoat level"; however, only international organizations organized trainings. ${ }^{60}$

55 Ibid.

56 See Commissioner for Human Rights of the Republic of Tajikistan. 2011. Strategy for 2011-2015. Dushanbe.

57 L. Krylova and N. Safarova. 2013. Gender Assessment: SDC Rural Drinking Water Program in Tajikistan. Dushanbe: Swiss Agency for Development and Cooperation. p. 5.

58 Aga Khan Foundation Tajikistan. 2014. Gender and Youth Study in Rasht Valley. Dushanbe. p. 11.

59 Gender Assessment: SDC Rural Drinking Water Program in Tajikistan, p. 5.

60 Gender and Youth Study in Rasht Valley, p. 12. 


\section{Data Collection: Statistics and Indicators}

Sex-disaggregated data and gender statistics reveal information, "vital to the development of policies and programs promoting gender equality and women's empowerment...and can contribute significantly to the achievement of sustainable and inclusive economic growth and development overall." ${ }^{61}$

The Agency for Statistics under the President of the Republic of Tajikistan (Statistics Agency) consists of a central office, regional offices, and local departments. National statistics legislation is gender neutral, and gender statistics are only referred to in explicitly equality-based laws, strategies, and GAPs. The agency does not have a gender statistics division, nor is gender mainstreaming a regular practice. ${ }^{62}$ Despite these limitations, the agency's capacity to produce and report sex-disaggregated statistics has increased. ${ }^{63}$ In 2013, the Statistics Agency adopted an internal work plan, the Program on the Development of Gender Statistics in Tajikistan for 2014-2015, which prioritizes the gender statistics regulatory framework, capacity building of national and local experts, and improving the production, dissemination, and use of such statistics. Since 2007, the agency has published the Women and Men of the Republic of Tajikistan compilation online (www.stat.tj/) in Tajik, Russian, and English. Countrywide household surveys conducted in cooperation with line ministries and international organizations are another important gender-sensitive data source.

The CEDAW Committee has drawn attention to the "lack of detailed statistical data, disaggregated by sex, age and nationality" of particularly disadvantaged groups of women, including refugees, seniors, migrants, women left behind by male migrants, and the disabled of all ages. ${ }^{64}$ Disparities between the lives of women and girls in rural and urban areas are obscured in official statistics that are aggregated (although gender data disaggregated by region do exist). FGDs revealed several data collection gaps, for example, the number of women in local government, rates of girls' school attendance, and information about women with disabilities, as well as discrepancies between sources. Where possible, international organization- or NGO-collected data supplement official statistics.

D. Abdurazakova and J. Gardner. 2012. Gender Statistics in the Southern Caucasus and Central and West Asia. Manila: ADB. p. 3.

62 National Review of the Republic of Tajikistan to Implement the Beijing Declaration and Platform for Action, p. 46.

63 ADB has provided technical support to improve gender statistics capacity in Tajikistan under the regional assistance project in Central and West Asia-Promoting Gender-Inclusive Growth in Central and West Asian Developing Member Countries.

64 Concluding observations on the combined fourth and fifth periodic reports of Tajikistan, para. 31. 


\section{CRITICAL GENDER ISSUES}

National programs and strategies on improving women's status, as well as periodic international agreement progress reviews, such as Convention on the Elimination of All Forms of Discrimination Against Women (CEDAW) reports, the Beijing Platform for Action, and the Millennium Development Goals (MDGs), highlight where gender gaps are the widest in Tajikistan. Gender experts and focus group discussion (FGD) participants concurred with these periodic reviews that the most critical barriers to gender equality were (i) women's minimal role in leadership and decision-making; (ii) limited access to economic resources, low labor participation, and the effects of labor migration; (iii) impaired education; (iv) gender-based violence (GBV), particularly domestic violence; and ( $v$ ) household dynamics. These lingering barriers are observed in the sectors where the Asian Development Bank (ADB) operates, potentially undermining its projects' objectives.

\section{A. Women in Power and Leadership}

During the Soviet period, women occupied $25.8 \%$ of management positions in the Tajik Soviet Socialist Republic, in large part due to quotas. ${ }^{65}$ Nonetheless, "the relatively high percentage of women active in public life...did not automatically translate into meaningful decision making power or influence." ${ }^{66}$ Quotas for women no longer exist, and the stereotype remains that men are natural leaders and women are better suited to supporting roles. When asked during an FGD in Kurgan-Tyube who are usually decisionmakers, the participants explained that, "men are ministers and women are deputy ministers," meaning that while women are involved, they are not leaders.

Several national policies and programs have tried to increase women's presence in leadership positions. Only the Main Directions of State Policy to Ensure Equal Rights and Opportunities for Men and Women for 2001-2010 had a specific target (a minimum of $30 \%$ women's representation in public bodies) and included a "soft quota" (compulsory participation of female and male candidates in recruitment for official posts). Current policy documents, such as the State Program for the Education, Selection and Placement of Capable Women and Girls in Leadership Positions for 2007-2016, acknowledge the various obstacles to women taking up management positions and realizing their full potential, but they do not set forth measures to bring this about.

65 Data are from a 1989 census. Political Party Regulations and Women's Participation in Political Life in Tajikistan, p. 59. 66 Ibid. 


\section{Women in Politics and Public Office}

\section{Women in Civil Service}

A key indicator of women's role in leadership and access to public sphere decision-making is the number of women in government, including elected and appointed positions. It is also important to distinguish between women working as civil servants and as managers, the ranks that women have attained, and the branches of government in question. In Tajikistan, efforts have been made both to increase the number of women in government generally and also in leadership positions. Gender experts agree that the 2001-2010 state equal rights program led to a significant increase in women's representation in civil service and, to a lesser extent, in top management positions. While this is important, women still tend to work in limited sectors and occupy very few top posts, either nationally or regionally. Using the $30 \%$ critical majority as a measure (the representation considered necessary to influence decision-making), equality challenges remain.

From 2003-2012, the number of women working in national and local authorities increased to $44.7 \% .{ }^{67}$ In 2014 , women accounted for $23.4 \%$ of all employees in public administration (4,393 women). ${ }^{68}$ However, women occupied only $17.1 \%$ of leadership positions in national and subordinate structures combined (528 women). ${ }^{69}$ Within public administration, women are best represented in social welfare and social insurance, followed by the justice sector. Women make up only a third or fewer of civil servants in executive activities, lawmaking, and socioeconomic management. ${ }^{70} \mathrm{~A}$ clear trend has also been observed with respect to nonelected posts: the higher the level of public office, the fewer the number of female appointments. "Every third unit manager is a woman, but only $5 \%$ of the top managers in government bodies are female."71

Women have made notable gains in management in some ministries, but remain underrepresented in others. Comparing the number of women in line ministry and state agency leadership posts in 2007 and 2014 shows an increase in the proportion of female leaders in the Ministry of Agriculture (none in 2007 to 20\% in 2014) and the Agency for Land Management (none to 24\%). ${ }^{72}$ Notably, both these organs belong to the tripartite gender network (see the section above on national mechanisms), and the promotion of women to leadership positions is strong evidence of the effectiveness of an explicit gender mainstreaming policy within government offices. Perhaps most concerning, the number of women in leadership positions in the Ministry of Education fell from $20 \%$ to $8 \%$ in the same seven-year period. ${ }^{73}$ Furthermore, the water and finance ministries presently have no female managers.

67 M-Vector Research and Consulting. 2013. Women Rule! The Transformation of the Role of Women in Tajikistan. 28 August. http:// www.m-vector.com/ru/news/?id=318 [in Russian]

68 Committee of Women's and Family Affairs. 2014. Press conference of the Committee on Women and Family Affairs under the Government of the Republic of Tajikistan. 30 July. http://kumitaizanon.tj/ru/news/id/150.

69 Ibid.

70 Millennium Development Goals, Tajikistan Progress Report. p. 64

71 Political Party Regulations and Women's Participation in Political Life in Tajikistan, p. 63.

72 Women and Men of the Republic of Tajikistan, p. 139. [English version]; Women and Men of the Republic of Tajikistan, p. 115-116. [Russian version].

73 Note that due to reorganization of some ministries, some data from 2007 are not directly comparable to those of 2014. 


\section{Table 2: Civil Servants in Selected Ministries, Committees, and State Agencies in Management and Specialist Posts, 2014}

$(\%)$

\begin{tabular}{|c|c|c|}
\hline Office & $\begin{array}{c}\text { Proportion of } \\
\text { Women Managers }\end{array}$ & $\begin{array}{c}\text { Proportion of } \\
\text { Women Specialists }\end{array}$ \\
\hline Ministry of Justice & 25 & 30 \\
\hline Ministry of Agriculture & 20 & 21 \\
\hline Ministry of Education and Science & 8 & 33 \\
\hline Ministry of Irrigation and Water Resources & 0 & 38 \\
\hline Ministry of Labor, Migration and Employment & 25 & 44 \\
\hline Ministry of Finance & 0 & 43 \\
\hline Ministry of Transport & 11 & 20 \\
\hline Ministry of Economic Development and Trade & 13 & 49 \\
\hline Ministry of Health and Social Protection & 28 & 90 \\
\hline Ministry of Industry and New Technologies & 10 & 32 \\
\hline State Committee on Investments and State Property Management & 9 & 11 \\
\hline Committee on Environmental Protection & 13 & 24 \\
\hline Agency for Construction and Architecture & 61 & 21 \\
\hline Agency for Land Management, Geodesy and Cartography & 24 & 27 \\
\hline
\end{tabular}

Source: Government of Tajikistan, State Statistics Agency. 2014. Women and Men of the Republic of Tajikistan. Dushanbe. pp. 115-116.

\section{Women Leaders in National Office}

Women presently make up only $15 \%$ of national parliamentarians. The bicameral Majlisi Oli (Supreme Assembly) of Tajikistan, features the Majlisi Milli (upper chamber, with 34 seats indirectly elected and appointed), and the Majlisi Namoyandagon (lower chamber, with 63 seats that are directly elected for five-year terms). Currently, a woman is a deputy chair of the Majlisi Oli (her second term in this post), and two of nine parliamentary committees are headed by women.

Table 3: Proportion of Women in the Majlisi Oli, 2015

\begin{tabular}{cccc} 
& $\begin{array}{c}\text { Seats } \\
\text { currently } \\
\text { filled }^{\text {a }}\end{array}$ & $\begin{array}{c}\text { Number } \\
\text { of } \\
\text { women }\end{array}$ & $\begin{array}{c}\text { Proportion of } \\
\text { Women } \\
(\%)\end{array}$ \\
\hline Majlisi Oli (Supreme Assembly) & 95 & 18 & 19 \\
\hline Majlisi Milli (upper chamber) & 32 & 6 & 19 \\
\hline Majlisi Namoyandagon (lower chamber) & 63 & 12 & 19.0 \\
\hline
\end{tabular}

${ }^{a}$ As of September 2015.

Sources: Websites of the Inter-Parliamentary Union Women in National Parliaments (http://www.ipu.org/wmn-e/world.htm) and of the Majlisi Oli of the Republic of Tajikistan (http://www.parlament.tj/en/) and (www.majmilli.tj). 
Since independence, women have not reached $30 \%$ representation in either chamber of parliament. The number of female members of parliament (MPs) in the upper chamber has steadily decreased, but the number in the lower chamber has increased slightly with successive elections. It should be noted that there is a great deal of variation in national data depending on the information source, the recording date, and official statistics aggregating all civil servants working in the national parliament. ${ }^{74}$ Using available data below, illustrates the women's representation dynamic. Twelve women won seats in the Majlisi Namoyandagon in the 2010 elections, but this number declined when two MPs were appointed to be deputy prime minister and head of the Women's Committee, respectively. Their seats were unfilled until the 2015 election, when 12 women again became MPs.

Figure 3: Proportion of Women in the Upper and Lower Chamber of the Majlisi Oli by Year, 2005, 2010, 2015 (\%)

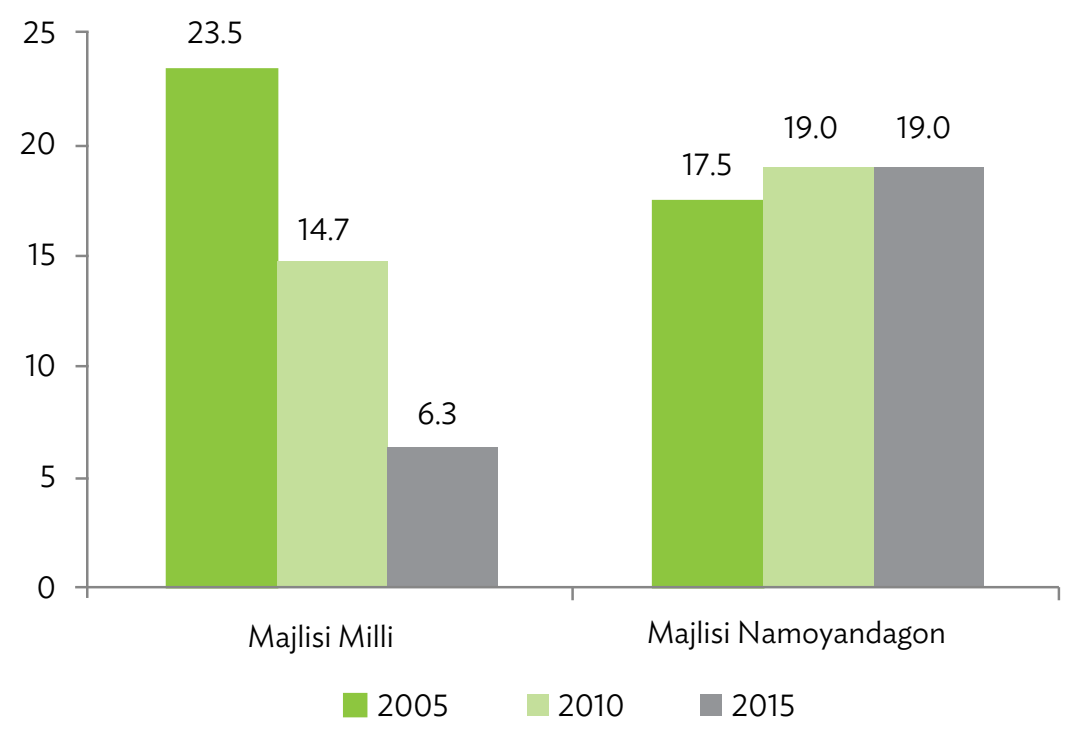

Note: Figures for 2005 and 2010 compiled from the Inter-Parliamentary Union. Number of MPs in the Majlisi Namoyandagon verified through official parliament website.

Sources: Websites of the Inter-Parliamentary Union Women in National Parliaments (http://www.ipu.org/wmn-e/ world.htm), and of the Majlisi Oli of the Republic of Tajikistan (http://www.parlament.tj/en/).

Women's representation in executive decision-making roles is lower than in parliament. Currently, a woman serves as deputy prime minister responsible for social affairs; of 14 line ministries, only the Ministry of Labor, Migration, and Employment is headed by a woman.

74 For example, the state report to the CEDAW Committee indicates that women constituted 34.1\% of Majlisi Namoyandagon parliamentary representatives in 2010. (Consideration of reports submitted by States parties under article 18 of the Convention on the Elimination of All Forms of Discrimination Against Women, Combined fourth and fifth periodic reports. Annex II). In the same year, this figure was recorded as only $19.05 \%$ in a report on progress toward MDGs. (Millennium Development Goals, Tajikistan Progress Report. p. 64). 
Women head three state bodies (the Women's Committee, the Committee on Language and Terminology, and the State Statistical Agency). ${ }^{75}$ As a rule, one deputy position in ministries, government agencies, and local executive bodies is unofficially "reserved" for a woman-a legacy of the 2001 state program. The impact of this policy is discussed in more detail in the following section.

\section{Box 1: Tajikistan's First Female Presidential Candidate}

During the 2013 presidential election, the Union of Reformist Forces, a coalition of the Islamic Renaissance Party and the Social Democratic Party, nominated a female candidate, Oynihol Bobonazarova, generating considerable excitement among the electorate. Not only was Ms. Bobonazarova's candidacy unexpected in a conservative and patriarchal society, she was also considered a legitimate opposition candidate due to her experience as a lawyer, human rights activist, and civil society leader. Some political analysts felt that, as an outsider, Ms. Bobonazarova would be able to "build consensus among two segments of the electorate-the secular and the religious." Ultimately, however, Ms. Bobonazarova failed to meet Central Election Committee registration requirements and was not included on the ballot. ${ }^{b}$ It is unclear to what extent her nomination was a serious bid for the presidency (she was nominated only a few months before the election and her platform included a pledge that she would serve only as a transition leader while reforms were implemented), but Ms. Bobonazarova's participation nevertheless played an important part in initiating a public discussion about women's ability to compete for high public offices in Tajikistan.

a K. Parshin. 2013. Tajikistan: Surprise Presidential Candidate Shakes Up Political Scene. Eurasianet.org. 25 September. http:// www.eurasianet.org/node/67549

b D. Trilling. 2013. Tajikistan's Opposition Challenger Forced Out of Presidential Race. Eurasianet.org. 11 October. http://www. eurasianet.org/node/67616

\section{Women Leaders in Local Government}

Data about women's representation in local offices are incomplete (or are not sufficiently disaggregated), making it difficult to determine whether it has increased, as is officially claimed. Still, it is clear that women are best represented in posts at the lowest governance levels. Whereas women account for approximately $17 \%$ of all employees in central government management positions, they hold $21.8 \%$ of such positions in local government offices and $22.4 \%$ in self-governing bodies at the village level. ${ }^{76}$

According to government reports, as of 2013,517 women were elected to all people's deputies assemblies (majlisi) at the provincial, municipal, and district levels combined (as compared to 459 in 2011 and 404 in 2005). ${ }^{77}$ Considering only the provincial majlisi, women hold $11.6 \%$ of seats. ${ }^{78}$ In terms of leadership within the majlisi, $23 \%$ of chairpersons were women in $2014 .{ }^{79}$ (For comparison, in 2012 it was reported that women accounted for $5.9 \%$ of chairpersons and $43 \%$ of deputy chairpersons). ${ }^{80}$

\footnotetext{
National Review of the Republic of Tajikistan to Implement the Beijing Declaration and Platform for Action, p. 32.

6 National Review of the Republic of Tajikistan to Implement the Beijing Declaration and Platform for Action, p. 32.

77 Government of Tajikistan. 2013. Implementation of the International Covenant on Economic, Social and Cultural Rights, Second and third periodic reports. para. 17(b) and 2011. National report submitted in accordance with paragraph 15 (a) of the annex to Human Rights Council resolution 5/1 (Universal Periodic Review process). para. 39.

78 National Review of the Republic of Tajikistan to Implement the Beijing Declaration and Platform for Action, p. 32.

79 Ibid.

80 Consideration of reports submitted by States parties under article 18 of the Convention on the Elimination of All Forms of Discrimination against Women, Combined fourth and fifth periodic reports, para. 86.
} 
Subnational executive bodies (the hukumat of the province, district, or municipality) are headed by a presidentially appointed, assembly-approved chairperson. Dushanbe local administration has the same status as provincial governments. Town- and village-level administration, however, is carried out by a directly elected jamoat chairperson; there are 370 jamoats in Tajikistan. Similar to the pattern of national government, women are best represented at the lowest or most local level. There are no women heading any of Tajikistan's five provinces. Data are incomplete, but it does appear that there has been a slight increase in female chairpersons (mayors) at the district and municipal levels combined (see Table 4, below).

Of all government offices, women are best represented as leaders at the jamoat level; in 2014 , they accounted for more than $40 \%$ of chairpersons. Women's jamoat achievements may be related to these leadership positions coming with less power and prestige than higher posts, and, thus, less competition. At the same time, given the high rate of male outmigration from many villages and settlements, there may be a lack of qualified men to take office. Still, the influence of national policies should not be discounted. According to participants of a Panjakent FGD, the state equal rights and opportunities program (characterized by one speaker as "demand from the top") resulted in more women in local leadership. Of 14 jamoats, only one was headed by a woman before the program was introduced; now, three are. Women are also being elected to such positions by their constituents. A participant of a Dushanbe FGD spoke about a recently elected female jamoat chairperson and the positive local changes, including weekly rubbish collection. In the opinion of the speaker, "it's a totally different atmosphere and all has changed for the better because there is a woman leader now." FGD participants said that male leaders tend to think about themselves and their friends in office, while women are more likely to think about community problems.

Table 4: Proportion of Women in Local Executive Offices, 2010, 2014 (\%)

\begin{tabular}{|c|c|c|}
\hline Position & $\begin{array}{l}\text { Proportion of } \\
\text { women, } 2010\end{array}$ & $\begin{array}{l}\text { Proportion of } \\
\text { women, } 2014\end{array}$ \\
\hline \multicolumn{3}{|l|}{ Provincial level } \\
\hline Chairperson (governor) & 0 & 0 \\
\hline Deputy chairperson & 35.6 & no data \\
\hline \multicolumn{3}{|l|}{ District and municipal level } \\
\hline Chairperson (mayor) & 5.6 & 9.0 \\
\hline First deputy chairperson & 2.8 & no data \\
\hline Deputy chairperson & 36.1 & 34.0 \\
\hline \multicolumn{3}{|l|}{ Jamoat level } \\
\hline Chairperson & 20.5 & 43.0 \\
\hline Deputy chairperson & 40.2 & no data \\
\hline
\end{tabular}

Sources: A. Kuvatova. 2014. Women and Farming: Gender Analysis in Agriculture of the Republic of Tajikistan. Dushanbe. p. 4 (2010 data); Government of Tajikistan. 2014. National Review of the Republic of Tajikistan to Implement the Beijing Declaration and Platform for Action. p. 32 (2014 data). 


\section{Barriers to Women Entering Government}

The reasons for women's underrepresentation in governance, and in leadership positions generally, vary. Both societal perceptions of the "appropriate" female role and structural factors limit women's access to positions of power.

The 2001 state equal rights program at once increased the number of female government officeholders, but also reinforced the notion and "custom" that women are best suited to deputy positions. Rather than achieving parity, "women rarely make it beyond deputy positions in the Tajik government, and instead remain stuck in the lower ranks or hit a glass ceiling after reaching middle management." 81 The state program, "did not envisage promoting women to top leadership positions in state authorities and limited the possibilities of appointing women to management in security and defense-related government departments." 82 Arguably, the program has not empowered women, but created another barrier to their advancement. Stereotypes about women as "homemakers" are reinforced by government officials and through the media. ${ }^{83}$ There is little positive media coverage that would portray a woman as a leader, politician, or party activist.

Men dominate government; without a critical majority, women have great difficulty overcoming the "hidden discrimination" in hiring for senior positions and during competitions for civil service. ${ }^{84}$ Women already in political office are not immune from these stereotypes and discriminatory attitudes, and "many women party members, candidates and parliamentarians do not speak out on issues that affect women in particular or actively support other women as political actors," which "undermines opportunities for solidarity, peer mentoring, and joint advocacy." ${ }^{5}$

81 G. Sokieva. 2012. Tajik Women Hit Glass Ceiling. Institute for War and Peace Reporting. 23 July. https://iwpr.net/global-voices/tajikwomen-hit-glass-ceiling.

82 Political Party Regulations and Women's Participation in Political Life in Tajikistan, p. 62.

83 See, e.g., The Second Shadow Report on the Realization of the Convention on the Elimination of All Forms of Discrimination against Women by Public Organizations of Tajikistan, p. 28.

84 Ibid. p. 27

85 Political Party Regulations and Women's Participation in Political Life in Tajikistan, p. 69, 83 


\section{Box 2: Is Tajikistan Ready to Vote for Women?}

While the stereotype about women's domestic roles is deeply engrained, Tajikistan is also a modern country in which gender roles are changing. To what extent have societal attitudes toward women in public office changed? Many contend that voters, especially females, are unwilling to elect women politicians. A 2007 survey of 100 women leaders, in which $42 \%$ of respondents singled out "the mentality of the people" as the primary obstacle to women entering politics, appears to support this notion. ${ }^{a}$

On the other hand, a more recent opinion poll suggests that Tajik society may be increasingly willing to support female leaders. In a 2010 poll of 1,500 adults, the overwhelming majority stated that they would be "likely" to vote for a woman candidate if she was equally as qualified as the male candidate (44\% said they would be "somewhat likely," and 38\% said they would be "very likely"). Of the small group who answered "unlikely," most (51\%) explained their answer with the statement, "women should stay at home and are not suitable leaders."

A 2013 poll found that when asked how people in Tajikistan feel about an increase in women in leadership positions, $74.2 \%$ of respondents answered, "positive, because women can be good leaders." Only $21.9 \%$ answered, "negative, because women's place is in the home, kitchen, and raising children."

Notably, in the 2015 election of the Majlisi Namoyandagon, women made up around 19\% of all candidates (26\% of candidates in closed-list proportional votes and $17 \%$ of candidates registered in singlemandate districts), ${ }^{d}$ and women were ultimately elected in the same proportion. These figures suggest public confidence in female candidates and also that removing barriers for women to run for office would augment the number of women in parliament.

a A. Mamadazimov and A. Kuvatova. 2011. Political Party Regulations and Women's Participation in Political Life in Tajikistan. National Association of Political Scientists of Tajikistan: Dushanbe. p. 69, 83.

b International Foundation for Electoral Systems (IFES). 2010. Public Opinion in Tajikistan: 2010 Findings from an IFES Survey. Washington, DC.p. 13

c Poll conducted by the Central Asia Barometer. M-Vector Research and Consulting. 2013. Women Rule! The Transformation of the Role of Women in Tajikistan. 28 August. http://www.m-vector.com/ru/news/?id=318. [in Russian].

d IFES. 2015. Elections in Tajikistan. 2015 Parliamentary Elections. Frequently Asked Questions. Washington, DC. p. 8.

As a rule, women have less political experience than men and more limited opportunities to acquire the relevant skills. As noted above, there is no quota requiring women to be included in political parties, but parties are instructed by the government to include women in lists for elections with proportional representation. Interestingly, women are well represented in political parties. Of the current parliament factions, women's representation ranges from 49.3\% (Islamic Renaissance Party) to 25\% (Agrarian Party). The majority party, the People's Democratic Party, has 37.9\% female membership. ${ }^{86}$

Women do not, however, occupy party governing positions and have limited influence over policy. Women are usually active before parliamentary elections, "in order to attract voters, [but after], the proportion of active political party members usually shifts in favor of men." 87 Party charters are gender-neutral and none have policies or programs for promoting women or ensuring parity in governing bodies. ${ }^{88}$ The number of female candidates put forward during elections is also generally lower than their party representation. For example, in the 2015 parliamentary elections, women made up 14\%$18 \%$ of candidates on most party lists (the exceptions were the People's Democratic Party,

86 Consideration of reports submitted by States parties under article 18 of the Convention on the Elimination of All Forms of Discrimination against Women, Combined fourth and fifth periodic reports. Annex II, Table 6.

87 Political Party Regulations and Women's Participation in Political Life in Tajikistan, p. 67.

88 Ibid. p. 68 . 
with $41 \%$ female candidates, the Islamic Renaissance Party, with $26 \%$ female candidates, and the Democratic Party of Tajikistan, with no women candidates) ${ }^{89}$

Women are underrepresented on both central and regional election commissions, which would normally offer another avenue though which to learn about campaign and election procedures. During the 2010 parliamentary elections, for example, of all district election commissions, women accounted for only $21 \%$ of members and only $16 \%$ of leadership positions. ${ }^{90}$ There are few empowerment programs for women entering politics, and they also lack the specialized training in economics and finance that would qualify them managerial positions in these ministries. ${ }^{91}$

Women lack critical resources to run a successful political campaign or to work in top management. In a poll of 100 female leaders on why few women participated in politics, $30 \%$ cited difficulty attending to both domestic responsibilities and political affairs; when asked about obstacles for women, 22\% named lack of money. ${ }^{92}$ A 2004 legal amendment that introduced an election deposit is regarded as having a disproportionate impact on women. "[T] he law actually introduced a means-related barrier that deprives the overwhelming majority of educated people, including women, of their right to be elected to the Parliament. This was particularly damaging to women who have significantly lower incomes than men." 93

Finally, other factors play a significant role in whether or not women will consider entering politics or take on leadership positions, including their own ambitions and confidence. More than a third of surveyed women leaders cited "uncertainly about victory" as an obstacle to female politicians. ${ }^{94}$ Almost as many respondents (30\%) cited "family barriers," referring to a lack of family support as a limiting factor.

\section{Engagement in Civil Society}

In Tajikistan, women's representation as civil society leaders is greater than in other sectors. Women's influence in NGOs is two-fold: first, they provide women with a social activism platform, without necessarily having a particular gender perspective; second, women have played a leading role in advancing gender equality through NGOs. Although Tajikistan has come under criticism for periodic restrictions of civil society groups, a policy of consultation with and cooperation among government structures, international development organizations, and women's NGOs is supported in many official documents. "Women's NGOs are the main channels used by the Tajik government to increase the role of women in the socio-political development of the country." ${ }^{95} \mathrm{NGOs}$ offer women an avenue, alternative to politics, to lead national reforms and gain employment opportunities (especially international NGOs).

89 IFES. 2015. Elections in Tajikistan. 2015 Parliamentary Elections. Frequently Asked Questions. Washington, DC. p. 8.

90 Organization for Security and Co-operation in Europe (OSCE). 2010. Republic of Tajikistan Parliamentary Elections 28 February 2010 , Election Observation Mission Final Report. Warsaw. p. 20.

91 Human Development Report 2014-Sustaining Human Progress: Reducing Vulnerabilities and Building Resilience, p. 122

92 The Second Shadow Report on the Realization of the Convention on the Elimination of All Forms of Discrimination against Women by Public Organizations of Tajikistan, p. 28.

93 Political Party Regulations and Women's Participation in Political Life in Tajikistan, p. 73

94 The Second Shadow Report on the Realization of the Convention on the Elimination of All Forms of Discrimination against Women by Public Organizations of Tajikistan, p. 28.

95 A. Dar and M. Wani. 2012. Role of NGOs in the Development of Women in Post-Independent Tajikistan. The Journal of Central Asian and Caucasian Studies (OAKA) of the International Strategic Research Organization (USAK). 7 (14). p. 159. 
In Tajikistan, civil society can encompass a broad spectrum of organizations, "ranging from local organizations (communal councils, neighbor's councils, etc.) to more formal, officially registered public associations." ${ }^{96}$ Most of civil society operates as public associations (there were over 2,600 officially registered in 2013), ${ }^{97}$ but other community-based organizations, such as savings groups, water users associations (WUAs), and mahalla councils, also allow women to engage with local issues. The precise number of "women's NGOs" (public associations) is not known, in part because there is no single definition for what constitutes such an organization. Ministry of Justice data list approximately 71 such organizations in 2007,98 but other sources suggest that there are "more than a thousand NGOs registered in Tajikistan with diverse agendas for the upliftment of Tajik women." 99 Based on their function, $28 \%$ of the country's NGOs are considered "women's organizations". ${ }^{100}$ One of the best examples of women's civil society activism is the coalition "From de Jure Equality to de Facto Equality," which was formed in 2008 from 98 public organizations throughout the country. Today, the coalition comprises 77 of the most active women's NGOs in Tajikistan.

Women's NGOs fall into roughly two categories: those that work on social protection and provide direct community assistance (particularly empowerment through training and mobilization of services for survivors of domestic violence), and those that work nationally on advocacy and monitoring of gender equality commitments. "From de Jure Equality to de Facto Equality" played a critical role in lobbying for legal change (the adoption of a law on domestic violence, for example) and in presenting alternative views on the fulfillment of international CEDAW commitments and the implementation of national women's programs. The coalition includes specialist NGOs that represent particular constituents, such as rural women, women with disabilities, and female entrepreneurs.

Assessing women's NGOs' influence on governing processes is not straightforward. Cooperation between civil society and national institutions, primarily the Women's Committee, suggests that NGOs do have a significant voice. On the other hand, this kind of partnership is not always replicated locally. According to a study in two districts of Khatlon viloyat, little NGO knowledge on strengthening the role of women "enters the local governance process due to lack of exchange and dialog between NGOs and local government structures."101 Until recently, women's political civil society work was mainly limited to voter education of other women and did not include activism. During the 2010 parliamentary elections, however, not only was gender equality included in some party conferences, but also several representatives of women's NGOs, including coalition members, campaigned for the Majlisi Namoyandagon, as well as for regional, town, and district majlisi. ${ }^{102}$ The People's Democratic Party, for instance, nominated six female NGO representatives who were not party members, but were nevertheless seen as especially active in addressing women's issues. If this positive trend is nurtured effectively, there is a

96 ADB. 2011. Civil Society Briefs: Tajikistan. Manila. http://www.adb.org/publications/civil-society-briefs-tajikistan.

97 USAID. 2014. The 2013 CSO Sustainability Index for Central and Eastern Europe and Eurasia. Washington, DC. p. 208.

98 Y. Yusufbekov, R. Babajanov and N. Kuntuvdiy. 2007. Civil Society Development in Tajikistan. Dushanbe: Aga Khan Development Network. p. 51.

99 Role of NGOs in the Development of Women in Post-Independent Tajikistan. p. 160.

100 ADB. 2011. Civil Society Briefs: Tajikistan. Manila.

101 Gender Assessment: SDC Rural Drinking Water Program in Tajikistan, p. 5.

102 Political Party Regulations and Women's Participation in Political Life in Tajikistan, p. 81. 
great potential that women's civil society skills, "can be further cultivated into the type of skills important for participation in political life."103

Despite their accomplishments, women's NGOs still face serious limitations. Outside of the capital, they have limited capacity to conduct analysis and monitoring, which means that important information about regional women is not effectively presented. Women's NGOs also tend to specialize in social sector issues, such as health and education, and there are few organizations conducting gender-sensitive economic analysis, in part because this field is viewed as a "male sphere". The work of women's NGOs generally centers around improving women's lives, but rarely aims to change gender relations or engage men in equality initiatives (exceptions include the work of women's resource centers with male family members on domestic violence or girls' education). Although youth volunteerism is growing in Tajikistan, a respondent for this assessment pointed out that women's NGOs engage with few young women and expressed concern over the aging female civil society leadership.

The financial viability of women's NGOs is also a concern. Most CSOs in Tajikistan are completely dependent on external donors, ${ }^{104}$ and women's organizations are not an exception. This study assessed women's NGOs that were forced to close or contract dramatically due to lack of funding, particularly in regions where donor priorities had shifted. Because donors fund implementation, the project-driven model means that women's NGOs are often not able to pursue their own agendas, but instead rely on winning grants that fit within their mandates. In November 2014, almost 100 CSOs, including several women's NGOs, submitted an open letter to the government addressing draft amendments to the Law on Public Associations that would restrict NGO access to financial support through increased international grant regulation. ${ }^{105}$ While the proposed amendments would apply equally to all NGOs, women's organizations are especially dependent on foreign donors that support equality initiatives or follow mainstreaming policies. On the other hand, women's NGOs may be able to access specific funding through public procurement processes. In 2008, the Law on State Social Orders authorized state funds to be used for, among other needs, "work with women, strengthening families and assistance in addressing demographic and gender policy issues [as well as] the protection of the rights of mothers and children." 106 Information about the number of women's NGOs receiving state funds, or for which types of projects, was not available.

\section{B. Economic Opportunities for Women and Men}

Reducing poverty and improving living standards is a priority shared by the Government of Tajikistan and development partners. Tajikistan is one of the poorest former Soviet republics with a per capita gross domestic product (GDP) of $\$ 9.24$ billion in $2014 .^{107}$ National economic development projects reduced the poverty rate from $47 \%$ in 2009 to

\footnotetext{
103 Ibid.

104 USAID. 2014. The 2013 CSO Sustainability Index for Central and Eastern Europe and Eurasia. Washington, DC. p. 210.

105 International Federation for Human Rights (FIDH). 2014. Tajikistan: Drop draft legislation restricting NGO access to funding. 25

November. https://www.fidh.org/International-Federation-for-Human-Rights/eastern-europe-central-asia/tajikistan/16540-

tajikistan-drop-draft-legislation-restricting-ngo-access-to-funding.

106 Republic of Tajikistan. 2008. State Law on Social Orders of the Republic of Tajikistan, N 482. Dushanbe.

107 Trading Economics. 2016. Tajikistan GDP. http://www.tradingeconomics.com/tajikistan/gdp
} 
$36 \%$ in $2012,{ }^{108}$ but it remains high at $32 \%$ in $2014 .{ }^{109}$ Implementation of Tajikistan's Poverty Reduction Strategy for 2010-2012 contributed to economic growth, but the World Bank maintains that labor earnings and remittances are driving poverty reduction. ${ }^{10}$ Women's contribution to poverty reduction in terms of earnings has been less than men's, which is expected when considering women's much lower rate of economic activity and wage and employment gender gaps being considerable and favoring men. ${ }^{111}$ One of the largest challenges for the country is alleviating women's poverty vulnerabilities while expanding their economic independence.

\section{Poverty and Access to and Control over Assets}

There is virtually no gender difference in relative poverty rates, but households headed by females incur more poverty risk than households headed by males (see Table 5 below). According to the 2012 Tajikistan Demographic and Health Survey (TjDHS), 21\% of all households are headed by females, and there are 60,000 households consisting of single mothers with children. ${ }^{112}$ Note that these two categories are not equivalent, ${ }^{113}$ but a socioeconomic study carried out in 12 districts did confirm that households headed by females are smaller than others and most often consist only of women and their children.114

Table 5: Poverty Rates for Men and Women, and Households Headed by Males and Females (\%)

\begin{tabular}{lcc} 
& Rate of Relative Poverty & Rate of Extreme Poverty \\
\hline Total population & $\mathbf{5 3 . 5}$ & $\mathbf{1 7 . 1}$ \\
Men & 53.1 & no data \\
Women & 53.9 & no data \\
& & 16.0 \\
Households headed by males & 52.8 & 22.9 \\
\hline Households headed by females & 57.2 & \\
\hline
\end{tabular}

Source: Government of Tajikistan, State Statistics Agency and UNICEF. 2009. Tajikistan Living Standards Measurement Survey 2007. Dushanbe. pp. $17,30$.

The number of households headed by females is said to be increasing, which reflects labor migration rates. For many of these, remittances are the sole source of income. Female-headed households are more likely to have fewer employed family members and thus resort to borrowing money for food and other household goods. ${ }^{115}$ Chronic income shortages mean that such families cannot invest in human development efforts, such as education.

108 Republic of Tajikistan. 2013. Living Standards Improvement Strategy of Tajikistan for 2013-2015, Chapter 1. Dushanbe.

109 The World Bank. 2016. Data. http://data.worldbank.org/country/tajikistan

110 J. Azevedo, A. Atamanov and A. Rajabov. 2014. Poverty Reduction and Shared Prosperity in Tajikistan: A Diagnostic. Policy Research Working Paper 6923. Washington, DC: World Bank. p. 13.

111 Ibid. pp. 16- 17

112 Women and Men of the Republic of Tajikistan, pp. 8-9. [Russian version]

113 The International Labour Organization (ILO) defines a household headed by a female as one in which there either are no adult males owing to divorce, separation, migration, non-marriage, or widowhood, or where men do not contribute to the household income although they are present.

114 T. Bozrikova and Z. Bazidova. 2014. Situational Analysis Report: the Impact of Migration on the Socio-economic Vulnerability of Rural Women in Tajikistan. Dushanbe: UN Women. p. 29.

115 Ibid.p. 14. 
Women's ownership of and control over key resources is another economic autonomy indicator. Sex-disaggregated data about ownership of real estate, moveable property, or household assets is limited, but national survey data show that only around half of women have some ownership rights to housing, and less than $1 \%$ of these are sole owners. ${ }^{116} \mathrm{An}$ NGO-conducted study of 1,500 households found that, in the country as a whole, women represent $15.6 \%$ of owners of houses, $21.3 \%$ of apartment owners, and $2.4 \%$ and $2.3 \%$ of car and truck owners, respectively. ${ }^{117}$ Households headed by females are less likely than maleheaded households to have valuable goods such as cars, trucks, and computers.

There are also clear gender differences in land and livestock possession, as well as in size and quantity. While urban and rural women are equally likely to own a house, only $16.5 \%$ of urban women, as compared to $33.7 \%$ of rural women, own land in some form (women usually own land jointly). ${ }^{118}$ Comparing households headed by females to households headed by males, those headed by women that own land have smaller plots (an average area of 9.2 sotka as compared to 15.2 sotka for those headed by men). ${ }^{119}$ Likewise, $58.4 \%$ of households headed by men report owning some livestock (cattle, horses, mules, pigs, sheep, goats, poultry, etc.) as compared to only $38.7 \%$ of households headed by women, and the average number of livestock owned is less among households headed by females across all categories. ${ }^{120}$ Gender norms also play a role because women traditionally do not have rights to moveable household property. ${ }^{121}$ Women's limited property ownership has implications for their ability to access commercial loans because they can seldom meet collateral requirements.

Men and women's poverty coping mechanisms differ. Poverty is a major driver of men's labor migration as it impossible for them to support their families in Tajikistan. For women in a patriarchal society, there are fewer opportunities to overcome poverty. Although there are no data on the subject, experts have drawn connections between poverty and women agreeing to enter polygamous marriages as second or third wives as they see no other means to support themselves or their children. In fact, because religion is increasingly influential in Tajikistan, polygamy is "socially accepted, may be a good option, and may even be suggested by the relatives" of abandoned wives because it can offer them economic protection and stability. ${ }^{122}$ Women who are abandoned by their migrant husbands may resort to prostitution. Indeed, a survey of prostituted women in Dushanbe found that women who are not in relationships with their husbands (and, presumably, no longer receiving financial support) are more likely to engage in prostitution. From a sample of 100 prostituted women, half have only a primary education, are divorced, separated, or widowed (61.2\%), and have children (77.8\%). ${ }^{123}$

116 Government of Tajikistan, State Statistics Agency, Ministry of Health and ICF International. 2013. Tajikistan Demographic and Health Survey 2012. Dushanbe, Tajikistan, and Calverton, Maryland. p. 220.

117 The Second Shadow Report on the Realization of the Convention on the Elimination of All Forms of Discrimination against Women by Public Organizations of Tajikistan, p. 51.

118 Tajikistan Demographic and Health Survey 2012, p. 220.

119 A sotka is a measurement of area equivalent to 100 square meters. State Statistics Agency and UNICEF. 2009. Tajikistan Living Standards Measurement Survey 2007. Dushanbe. p. 131.

120 Ibid. pp. 134-135.

121 S. Sattar, M. Bierbaum, S. Barfieva, J. Flanagan, S. Lakhani, and R. Swinkels. 2013. Tajikistan Gender Diagnostics Note. Report No: ACS5015. Washington, DC: World Bank. p. 49.

122 IOM. 2009. Abandoned Wives of Tajik Labor Migrants. Dushanbe. p. 27.

123 Population Services International Research and Metrics. 2012. Central Asia Republics (2012): HIV and TB TRaC study understanding risk behaviors associated with HIV transmission and utilization of HIV prevention services among SWs in Almaty (Kazakhstan), Chui Oblast (Kyrgyzstan), and Dushanbe (Tajikistan). Washington, DC: USAID. p. 13. 


\section{Economic Activity and Employment Patterns}

Tajikistan's total labor force (i.e., the population ages 15-75 years that is able to work) numbers more than 2.9 million. For the last two decades, women have constituted around $45 \%$ of the total labor force. ${ }^{124}$ There are significant differences in women and men's economic activity rates. According to the 2009 Labor Force Survey, the most recent such survey conducted in Tajikistan, men had almost double the economic activity of women. Whereas $72.2 \%$ of men ages $15-75$ are economically active, only $39.1 \%$ of women are. ${ }^{125}$ Among the country's total female economically inactive population-women who are not employed, nor formally defined as unemployed (meaning they are not seeking formal work) $-80 \%$ are between the ages of 25 and 49 , and more than $90 \%$ are housewives. ${ }^{126}$ The main reasons for men's economic inactivity are disability and having no intention to work. ${ }^{127}$ The sharp decline in women's economic activity corresponds directly to the age at which they leave the labor market, marry, start families, and undertake household obligations. The labor participation gender gap stems from the difficulty of combining productive and reproductive activities, which is most acute for young urban women (ages 20-29), who have the lowest economic activity rate. ${ }^{128}$ Young men's absence from the labor market is largely due to their continued education. In addition to the burden of inequitably distributed, unpaid domestic work, a combination of women's generally lower level of education (especially vocational education), a lack of professional qualifications, the high fertility rate, the absence of childcare facilities (especially specialized facilities for children with disabilities), and gender stereotypes all place women in a weak employment position.

Official employment statistics indicate that fewer than half of employed persons work for wages (the number decreased 4\% from 2010 to 2013). ${ }^{129}$ Men are most likely to work as employers or to be self-employed (as own-account workers or as family workers), while women are more likely to work as employees and members of producers' cooperatives (which is considered a form of self-employment; see Figure 4). Note that these figures are based on the 2009 Labor Force Survey and indicators may well have changed since then (for example, according to 2013 national statistics, 59.4\% of all wage employees were male). Nevertheless, the general pattern in which women are entrepreneurially underrepresented continues.

Informal employment accounts for a large share of jobs in Tajikistan. In 2009, nearly half (49\%) of all employed persons were working informally. However, if the number of uncontracted individuals who nonetheless work in the formal sector are also counted, informal employment could be as high as 58\%. ${ }^{130}$ According to the 2009 Labor Force Survey, total informal employment was higher among men. There are no national statistics or estimates of the number of people employed informally, nor is there a single definition of informal employment. National labor surveys count unregistered entrepreneurial activities, work on family farms, and assisting family members in agricultural production.

124 Tajikistan Gender Diagnostics Note. Report No: ACS5015, p. 35.

125 National Review of the Republic of Tajikistan to Implement the Beijing Declaration and Platform for Action, p. 28.

126 Tajikistan Gender Diagnostics Note. Report No: ACS5015, p. 36.

127 Ibid.

128 I. Maltseva. 2007. Gender Equality in the Sphere of Employment. Dushanbe: UNIFEM. p. 7.

129 Women and Men of the Republic of Tajikistan, p. 94. [Russian version]

130 J. Kuddusov. 2010. Labor Market Review Tajikistan. Turin: European Training Foundation. p. 63; ILO. 2014. Maternity Protection and the Childcare Systems in Central Asia: National Studies in Kazakhstan and Tajikistan. Moscow. p. 28. 
Many women work in agriculture, in which informal employment is a common practice. Working without a formal contract has serious consequences for both men and women who are unprotected by national labor legislation and are not entitled to benefits, such as notice of dismissal, annual leave, sick pay, maternity leave, or pension payments. Informal employment for women is characterized as a "lack of secure employment and poor social protection; prevalence of hard forms of labour; low salary levels; absence of pensions and lack of opportunities for development and investment in human capital."131 Women's smaller pensions make them susceptible to poverty and dependence on relatives in old age.

Figure 4: Employment Status of Men and Women, 2009 (\%)

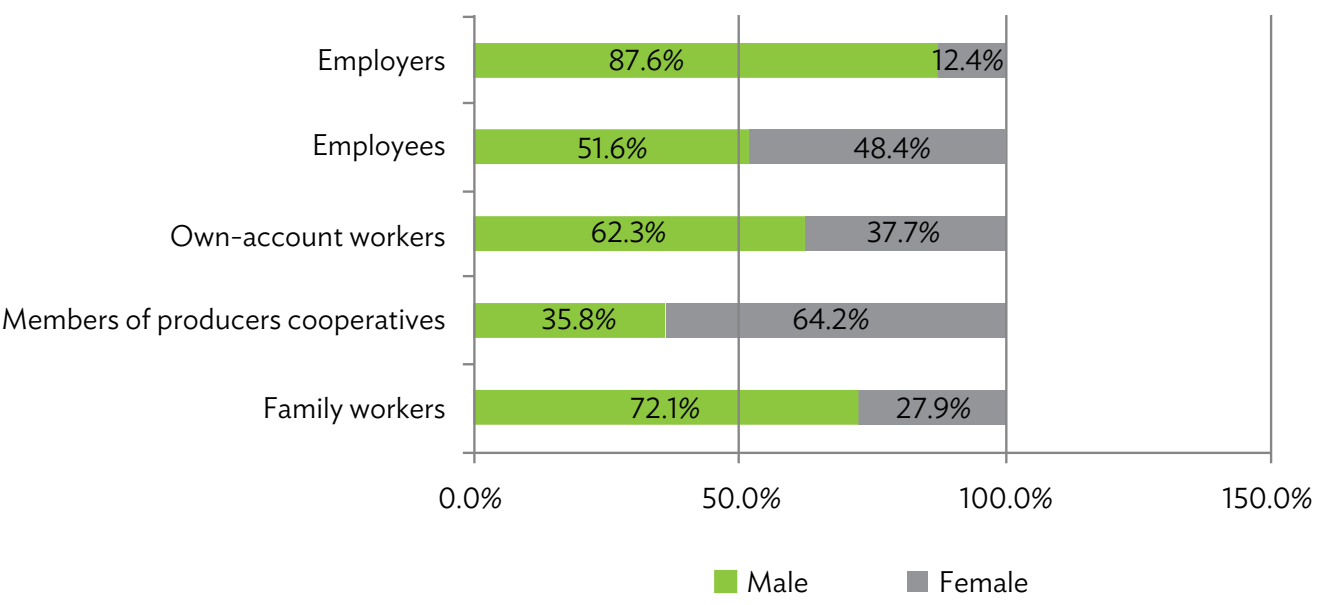

Source: United Nations Economic Commission for Europe Statistical Database, http://w3.unece.org/pxweb/. (accessed January 2015).

\section{Gendered Features of the Labor Market}

In addition to gendered employment differences, the labor market in Tajikistan exhibits segregation-both horizontal (the sectors where women and men work) and vertical (women's and men's position in employment hierarchies). Agricultural work is the largest employer of both women and men (49.5\% of all employed females and $44.2 \%$ of all employed males). ${ }^{132}$ In 2013, 84\% of all women employees were working in agriculture along with the traditionally female fields of health care and education, while the same sectors

131 ILO. 2009. Work and Family: The Republic of Tajikistan. http://www.ilo.org/moscow/information-resources/publications/ WCMS_312658/lang--en/index.htm.

132 Women and Men of the Republic of Tajikistan, p. 90. 
accounted for $66 \%$ of male employment. ${ }^{133}$ Although a majority of men are also employed by these industries, their employment patterns are still more diversified than women's.

Considering the structure of male and female employment, women are concentrated in unskilled jobs. The 2009 Labor Force Survey showed that $72.5 \%$ of employed women were unskilled. Male managers outnumbered female managers by an almost 4:1 ratio. There were 1.5 times more male specialists than female, and 6.7 times more male skilled workers in industry. ${ }^{134}$ Women who are skilled workers are more likely to occupy midlevel positions, and they outnumbered men in these positions by $10 \%$. Although it uses a different methodology from the Labor Force Survey, the 2012 TjDHS suggests that women may be transitioning from purely unskilled manual work $(45.3 \%$ of surveyed women were in this category) to professional and managerial roles (19.7\% of employed women). Still, these findings indicate the persistence of barriers to women's career advancement and the need to expand opportunities for them to gain a range of professional skills.

Figure 5: Distribution of Employed Women by Occupation, 2012

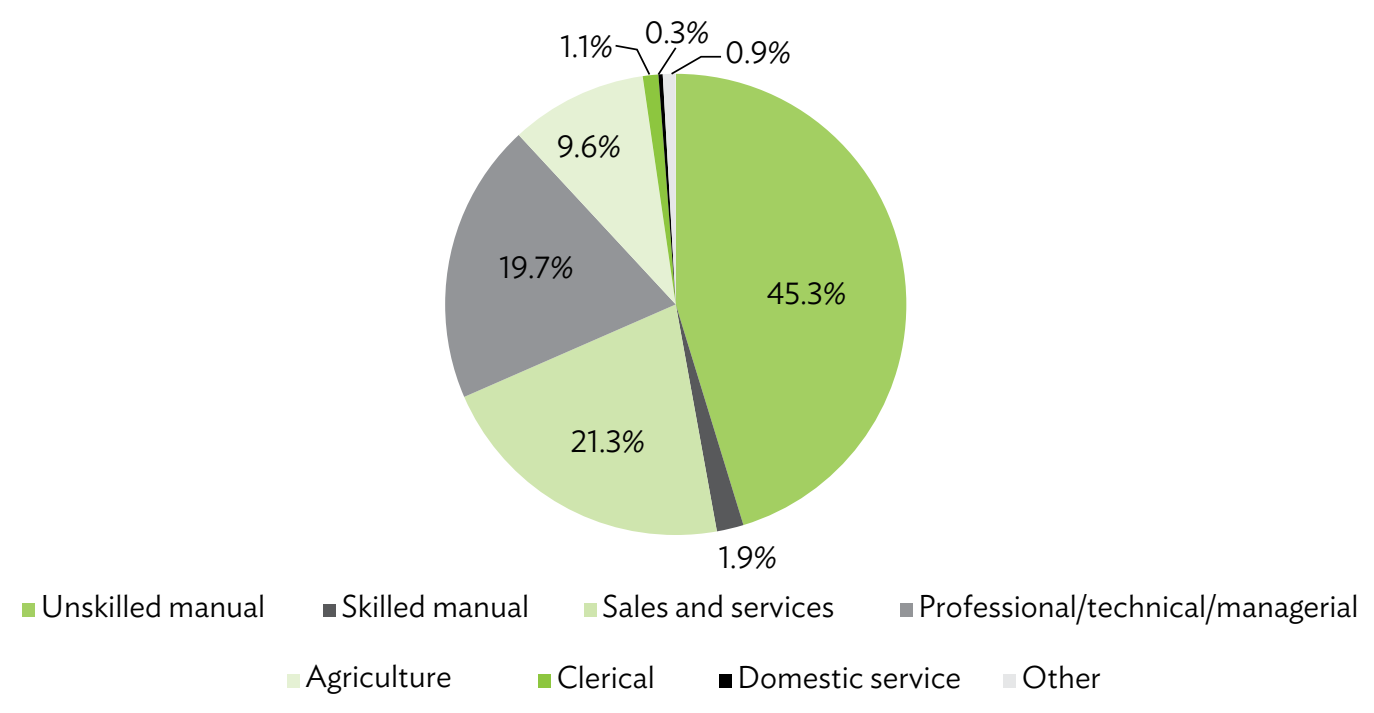

Source: Government of Tajikistan, State Statistics Agency, Ministry of Health and ICF International. 2013. Tajikistan Demographic and Health Survey 2012. Dushanbe, Tajikistan, and Calverton, Maryland. p. 39.

Women's predominance in poorly paid, low-skilled work and occupations, as well as in informal and part-time work, all translate to gendered earnings disparities. Women's monthly wages are consistently lower than men's across all occupations, but there is 
evidence of a narrowing wage gap. ${ }^{135}$ This could be partly attributable to wages being increased comprehensively by 2.3 times between 2006 and 2009, and in education and health care by $139 \%$ and $132 \%$, respectively. ${ }^{136}$ It is thought, however, that it will be difficult to achieve "substantial progress" in narrowing the gap further due to "increasing segregation in vocational education and the labor market." ${ }^{37}$

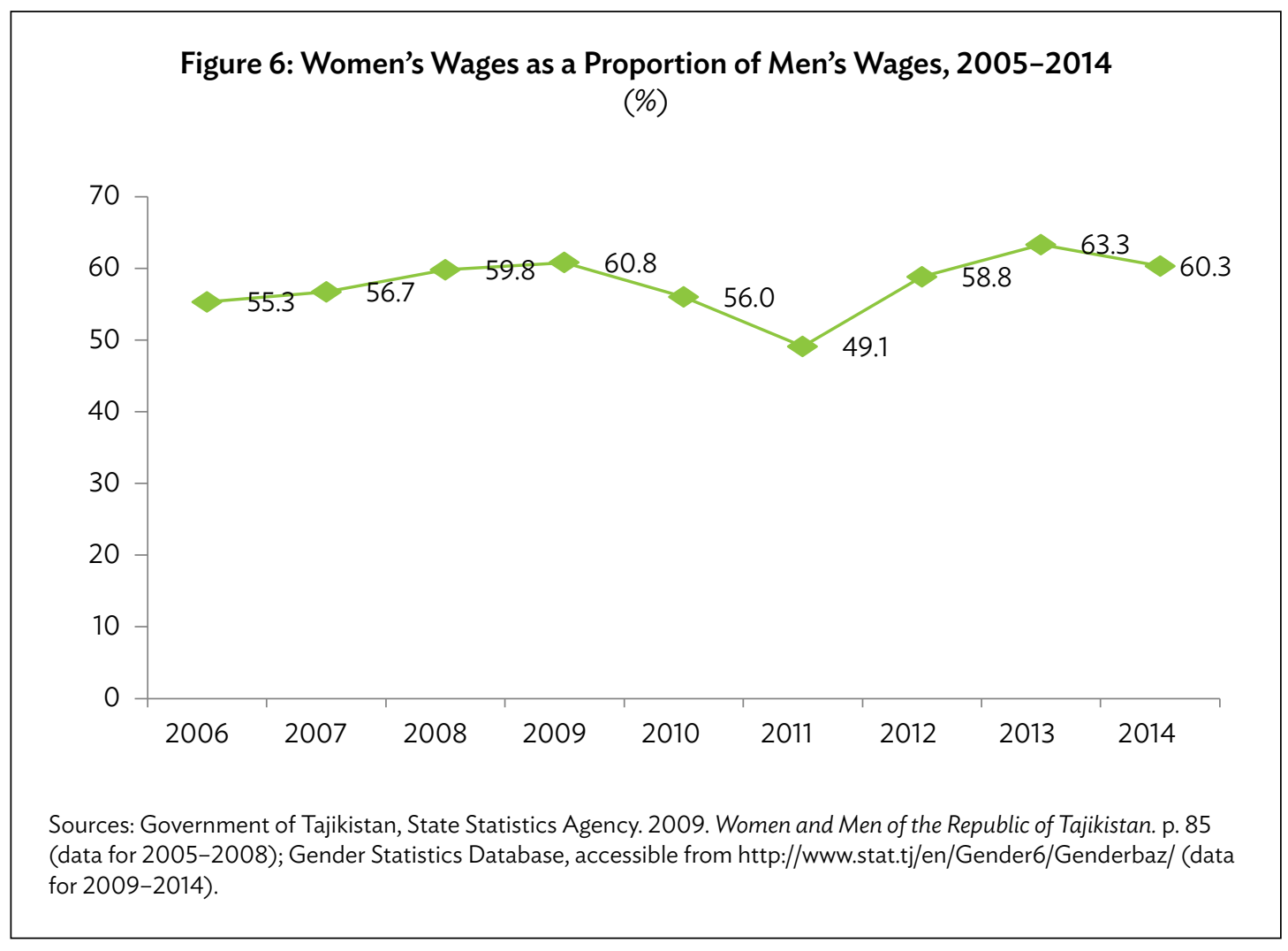

The World Bank estimates that only part of the gender wage gap can be accounted for in variables such as employment patterns. Therefore, much of the gap is due to gender-based discrimination. ${ }^{138}$ Despite labor law guarantees of equal pay for equal work, women receive lower pay, and this is not viewed as a serious problem since it is "stereotypically assumed that women have access to other resources through spouses and other family members." 139 In addition to salary differences, a considerable portion of women receive no pay for their work or are paid in-kind. According to the 2012 TjDHS, of women who worked at any time in the 12 months preceding the survey, slightly more than half were paid in cash only (53.4\%), the majority in nonagricultural work. Around one-fifth of all women were paid in cash and in-kind, approximately one in four was not paid (18.8\%), and $7.6 \%$ received only

135 Note that UNECE estimations of the gender pay gap in Tajikistan for 2005-2011 also show a narrowing but indicate that the difference between men's and women's average monthly earnings is larger than that shown in national statistics. Statistical Database, http:// w3.unece.org/pxweb/.

136 Consideration of reports submitted by States parties under article 18 of the Convention on the Elimination of All Forms of Discrimination against Women, Combined fourth and fifth periodic reports, Annex II, Table 10.

137 Millennium Development Goals, Tajikistan Progress Report, p. 62.

138 Tajikistan Gender Diagnostics Note. Report No: ACS5015, p. 40.

139 Millennium Development Goals, Tajikistan Progress Report, p. 62. 
in-kind payments..$^{140} \mathrm{~A}$ majority of women working in agriculture are not paid at all for their work (58.7\%), with the remainder more likely to receive either cash or in-kind payment.

Labor legislation protects women and their reproductive functions, but also reinforces stereotypes about women's primary responsibility for the family. The Labor Code provides women with fully paid maternity leave (140 days before and/or after delivery), and child care leave for a maximum of three years. It also prohibits women (and single fathers) with children under age three from certain overtime work, and regulates pregnant women's employment. The Labor Code does not stipulate any specific paternity leave, but does provide for child care leave for any family member or guardian. While all workers are entitled to unpaid leave for family circumstances, no men took child care leave in 2004 and $2009 .{ }^{141}$ It should be noted that some categories of working women, such as those on dekhan farms and those working from home, may not be eligible for maternity and child care benefits due to unclear tax regulations.

All women are prohibited from working in mining, in hazardous conditions, and in jobs involving manually lifting and moving heavy loads. ${ }^{142}$ In many instances, protective women's employment legislation has backfired. Employers perceive women as costlier to employ and prefer to hire men. ${ }^{143}$ In some instances, the law is even manipulated to exclude women from any post (even office-based) in construction or other industries interpreted to constitute "heavy work".

Persons with disabilities (PWDs) also face discrimination in finding work, and women with disabilities encounter particular barriers to employment. In a Sughd oblast survey of 164 PWDs, $36.6 \%$ were employed, with more women than men working. ${ }^{144}$ Most women worked in petty trade or as seamstresses, and the majority found work themselves or through friends and relatives. Of those who were not employed, most cited health reasons, but some cited lack of experience. Women with disabilities were divided about employment quotas for PWDs, but they emphasized enabling PWDs to organize work for themselves, especially as entrepreneurs. ${ }^{145}$ The survey also revealed that women with disabilities receive less pension than men (TJS24-280 compared to men's TJS30-300 per month). ${ }^{146}$

\section{Labor Migration and Changing Gender Dynamics}

Migration is widespread; by some estimates, one in four Tajik households have migrant members, with the total number reaching almost a million. The Russian Federation is their primary destination (hosting more than $90 \%$ of migrants), followed by other Central Asian countries (primarily, Uzbekistan), the People's Republic of China, and the United Arab

\footnotetext{
140 Tajikistan Demographic and Health Survey 2012, p. 40.

141 Maternity Protection and the Childcare Systems in Central Asia: National Studies in Kazakhstan and Tajikistan, p. 31

142 Republic of Tajikistan. 1997. Labor Code Republic of Tajikistan, N 38. (Unofficial Translation by the International Center for Not-forProfit Law). http://www.icnl.org/research/library/files/Tajikistan/labor_eng.pdf

143 Gender Equality in the Sphere of Employment. p. 10; Maternity Protection and the Childcare Systems in Central Asia: National Studies in Kazakhstan and Tajikistan, p. 30.

144 Bureau on Human Rights and Rule of Law, Disabled Women's League Istirok, and UN Women. 2011. Implementation of the Rights of People with Disabilities in Sughd Province, Republic of Tajikistan. Report on Monitoring Outcomes. Khujand. p. 74. [in Russian] 145 Ibid. p. 76

146 Ibid. p. 77
} 
Emirates (UAE) ${ }^{147}$ According to the Russian Federal Migration Service, men represented $82.8 \%$ of migrants to the Russian Federation-over 815,000 persons-in January 2015. ${ }^{148}$ In 2014, men ages 18-39 accounted for $71 \%$ of male migrants to the Russian Federation. ${ }^{149}$ Most men who migrate are married ( $90.2 \%$ according to one survey), but they rarely travel with their wives (only $4.9 \%$ of male migrants in 2010). ${ }^{150}$ Men migrate alone because their work is mainly seasonal, many have unregulated status, and it is expensive to take the family. While they earn higher wages than in Tajikistan, their earnings cannot support a family in the Russian Federation. Women are also reluctant to join their husbands in seasonal work due to their family and household responsibilities. Increasingly, however, men are seeking to remain in the Russian Federation, and family migration is becoming more common. ${ }^{151}$ Male children most often migrate (62\% of surveyed migrants), followed by heads of households themselves (fathers), indicating that the household members with the greatest financial obligations are those who migrate. ${ }^{152}$

The number of female migrants has been increasing since the 2008-2009 economic crisis. Women account for $15 \%-20 \%$ of labor migrants, with the number more than quadrupling from 2006 to $2012 .{ }^{153}$ Female migration has many of the same "push" factors as male migration, specifically the difficulty that families face trying to live solely on a male breadwinner's income. ${ }^{154}$ Women from Tajikistan first tend to go abroad following family members, often to join their husbands, or to find husbands who have stopped communicating, and then they find local work and become migrants. ${ }^{155}$ Women also migrate in place of their husbands, for example, if the latter are on the non-entry list for the Russian Federation. Most women consult with their husbands, in-laws, and own family regarding migration as they "often lack the confidence to make such a decision independently and their decisions are, to a significant extent, influenced by their relatives." 156 For a woman, labor migration can set up a contradictory situation: while she improves her economic status, she is also subjected to many more negative attitudes than men receive. Women, especially those who migrate alone, are often stigmatized and "accused of not fulfilling a 'woman's role' and of leaving children in the care of their grandparents."

The primary motivations for migration are high unemployment(especially among youth in rural areas), the large gap between domestic and foreign wages, and the collapse of former employment sectors due to structural changes. ${ }^{158}$ Men also migrate for political reasons, such as wanting to avoid conscription. ${ }^{159}$ In fact, the two peak seasons for migrants leaving Tajikistan are February-March, to undertake seasonal work, and August-September, when

147 S. Kurbanov. 2013. Gender Shape of Labor Migration in the Republic of Tajikistan. Dushanbe: State Statistics Agency. p. 2.

148 Migrant. Ferghana.ru. 2015. Official Data from FMS Dispels Rumors of Mass Departure of Labor Migrants from Russia. 23 January. http://migrant.ferghana.ru/tag/statistika. [in Russian].

149 Migrant.Ferghana.ru. 2014. Russia: The Number of Citizens of Central Asian Countries Has Decreased Compared to the Summer 08 December. http://migrant.ferghana.ru/tag/statistika. [in Russian].

150 Olimova, S. 2012. Tajikistan: The Role and Status of Women in Migrant Households. Diaspora. 2. pp. 86-123. http://www.demoscope. ru/weekly/2014/0583/analit01.php\#_FNR_1.

151 FIDH and Anti-Discrimination Center Memorial. 2012. From Tajikistan to Russia: Vulnerability and Abuse of Migrant Workers and their Families. p. 7.

152 Tajikistan: The Role and Status of Women in Migrant Households.

153 Gender Shape of Labor Migration in the Republic of Tajikistan. p. 3.

154 UNIFEM and ILO. 2009. A Needs Assessment of Women Migrant Workers. Central Asia and Russia. Almaty. p. 8.

155 Ibid.p. 26

156 Ibid. p. 22.

157 From Tajikistan to Russia: Vulnerability and Abuse of Migrant Workers and their Families, p. 6.

158 Gender Shape of Labor Migration in the Republic of Tajikistan. p. 1.

159 From Tajikistan to Russia: Vulnerability and Abuse of Migrant Workers and their Families, p. 7. 
young men with no plans to pursue higher education finish school and become eligible for military service.

Migration has come to be perceived as "male" work, and inevitable for young men in Tajikistan. The high proportion of men in migration is attributed to male-dominated professions being the most in demand in recipient countries, such as the Russian Federation (e.g., low-skilled work in construction, transport, oil and gas fields; and agriculture, as machine operators, mechanics, loaders, etc.). But gender stereotypes also play a role because, "maintenance of the family is almost exclusively the responsibility of males. Hence, households prefer to send men abroad to seek paid employment...."160 Decisions about migration are most often taken between the potential migrant and his parents, but in some cases parents make the decision independently. As a rule, wives are excluded from decision making as they occupy a subordinate role in the family. They are, however, not passive in the migration process. In a survey of wives, $29.9 \%$ reported that they contributed their own funds for travel expenses and $55.9 \%$ gathered information for their spouse. ${ }^{161}$ Women have a positive attitude toward their husbands' migration, despite the difficulties of living apart. In FGDs, women expressed understanding of the hardships that migrant men often endure in order to provide better lives for their families.

According to the World Bank, remittances accounted for 48\% of GDP in $2013 .{ }^{162}$ On average, the poorest rural and urban households finance close to $80 \%$ and $50 \%$ of their yearly consumption through remittances, respectively. ${ }^{163}$ While remittance-receiving families' education and healthcare is better than that of other households, a large portion of remittances is spent on immediate consumption needs. Surveys querying returned migrants about spending plans revealed the primary expenditure to be for food and basic necessities (59.7\%), followed by house renovation (21.5\%). ${ }^{164}$ Expenditures for weddings ranked higher than those for child support, health care, education, or investment in household businesses. ${ }^{165}$ Few households have bank accounts (only $2.9 \%$ of urban and $1.9 \%$ of rural households), ${ }^{166}$ which is another indication that remittances are generally not saved.

Spending and saving patterns depend greatly on who receives remittances and makes household budget decisions. It is uncommon for migrants to send remittances directly to their wives; in one survey, $59 \%$ of migrants sent money to their parents and only $2 \%$ to their spouses ${ }^{167}$ In another study, $39 \%$ of migrants sent remittances to their children's' caregivers, $27 \%$ to their parents, $21 \%$ to brothers, and $11 \%$ to other family members. ${ }^{168}$ Household heads, usually the migrant's father, make most remittance allocations, followed by his spouse, and then the migrant himself. Decisions about major expenditures (e.g., for house repairs, and buying livestock or furniture) are made collectively by the migrant's

160 Labor Market Review Tajikistan, p. 71.

161 Tajikistan: The Role and Status of Women in Migrant Households.

162 World Bank. 2013. Migration and Remittance Flows in Europe and Central Asia: Recent Trends and Outlook, 2013-2016. 02 October. http://www.worldbank.org/en/news/feature/2013/10/02/migration-and-remittance-flows-in-europe-and-central-asia-recenttrends-and-outlook-2013-2016.

163 A Danzer, B. Dietz and K. Gatskova. 2013. Tajikistan Household Panel Survey: Migration, Remittances and the Labor Market. Regensburg: Institute for East and Southeast European Studies. p. 2.

164 Ibid. p. 16

165 Although the government has taken steps to limit expenditure on family events, such as weddings, there is no evidence that households have reduced such expenditures and invested remittances in other areas. Every fifth male migrant below age 30 reported that wedding expenses were the main reason they migrated. Tajikistan Household Panel Survey: Migration, Remittances and the Labor Market, p. 15.

166 Tajikistan Demographic and Health Survey 2012, p. 19.

167 Tajikistan: The Role and Status of Women in Migrant Households. pp. 86-123.

168 UNICEF. 2011. Impact of Labour Migration on Children Left Behind in Tajikistan. Dushanbe: Oxford Policy Management. p. 40. 
parents, by the migrant's wife in consultation with her husband, or eventually by the migrant himself; the wife very rarely makes such decisions alone. ${ }^{169}$ Fathers most often make large purchases, while the wife generally is responsible for daily and incidental ones. Because women have limited household bargaining power and often do not receive remittance payments directly, it has been suggested that "the welfare of women and their children in such a position is sometimes neglected in favor of capital expenditures such as household improvements." 170

Studies conducted among returned migrants suggest that although men receive some positive benefits of migration, such as increased knowledge, professional skills, and life experience, they often cannot fully realize them. In a survey of 1,000 returned migrants (85\% of whom were men), the large majority found employment when abroad (78.5\%), but half worked without signed contracts, and most performed unskilled work. ${ }^{171}$ For many young men, migration, "interferes with [their] career development...because when abroad migrants seldom work in their specialism and, as a rule, lose skills they had prior to departure as well as...necessary connections that could help them to find a decent job in their home country.... Returned migrants often have no opportunity to use their experience and qualifications gained abroad due to the low level of technical development of enterprises in Tajikistan." 172 A very small number of migrants received training when abroad (5.3\%); of those, most received it in the workplace and without any formal certification. ${ }^{173}$ At the time the survey was conducted, about half of the returned migrants were unemployed, and virtually none were aware of any official assistance in Tajikistan.

The migration experience can also have serious consequences for men, some of whom suffer exploitation and abuse. While migrants themselves complain primarily about lack of access to health care, as well as police and border guard mistreatment, human rights organizations have documented a rise in aggression and xenophobia in Russia, leading to assaults on migrants, as well as cases of forced labor and trafficking. ${ }^{174}$

Even in the absence of husbands and male heads of households, gender roles and authority over decisions change little, and women's empowerment is quite limited. Three groups of women are impacted by migration: wives of "successful migrants" (meaning those who regularly send remittances to the family), abandoned wives of labor migrants, and women who migrate, either independently or with their husbands.

A migration and gender role study that included a survey of 350 migrants and interviews with 40 migrants' wives concluded that "despite changes in gender roles within migrants' families, there is no doubt that a major part of household management remains in the hands of men." 175 When men are absent, power and responsibility are redistributed in accordance with the deeply traditional hierarchy of family roles, and they are entrusted to the oldest man or eldest son; only if they are absent do they go to the oldest woman. Alternatively, household functions can be redistributed among the family with the head

169 Tajikistan: The Role and Status of Women in Migrant Households.

170 Impact of Labour Migration on Children Left Behind in Tajikistan, p. 40

171 J. Kuddusov. 2010. Migration Survey: Migration and Skills in Tajikistan. Turin: European Training Foundation. p. 27.

172 Ibid. p. 37.

173 Ibid. p. 29.

174 See generally, From Tajikistan to Russia: Vulnerability and Abuse of Migrant Workers and their Families.

175 Tajikistan: The Role and Status of Women in Migrant Households. 
of the household involved via phone calls. ${ }^{176}$ Interactions with local authorities and the community is the responsibility of the household head; if he is absent, another man (his son, brother, etc.) will fulfill this function.

Interviewees for this assessment drew attention to the plight of abandoned wives and families of labor migrants who no longer receive remittances, or receive very irregular and small remittances, and have no contact with their husbands. ${ }^{177}$ Abandonment can be the migrant worker's choice, as many men find new partners and new lives abroad and prefer not to return to Tajikistan. Arranged marriages may be a factor, and migration gives men "a good opportunity to separate from a wife who they never really felt close to." 178 Other migrants struggle to find work and earn enough to send home, or they fall into difficult circumstances, such as alcohol or drug dependency, homelessness, or they sustain injuries, and they lose touch with their families. The 2008-2009 financial crisis and the collapse of the ruble in late 2014 have also impacted migrants who become effectively trapped in the Russian Federation.

Abandoned families live in extreme poverty, mainly subsisting on what they can produce and with infrequent assistance from relatives. ${ }^{179}$ In 2009, the International Organization for Migration (IOM) estimated that "between 230,880 and 288,600 families could be considered economically abandoned and living at or below the poverty level" based on the amount of remittances. ${ }^{180}$ In an IOM survey of 77 abandoned wives, $91 \%$ had not received any remittances in the last year and fewer than $3 \%$ received an amount above the poverty threshold. In fact, 40\% had never received remittances at all. When they did receive funds, it was primarily via bank transfer (77\%), but a not insignificant number received payments through relatives or acquaintances (18\%).

In order to cope with the lack of income, about half the women surveyed by IOM found temporary or fixed employment (most in agricultural work), earning an average monthly income of TJS50-100. Women typically earn income through home-based agricultural production, but men often supervised selling such goods (in $27.5 \%$ of households, women sold their own products, while in $30 \%$ the husband's male relatives managed sales). ${ }^{181}$ In terms of controlling their own incomes, most surveyed migrants' wives (57.5\%) consult with their husbands, his parents, or other relatives about spending; $22.5 \%$ give their income to the head of household, and only $17.5 \%$ report that they manage their own income. Earnings are typically sufficient only for daily household needs, primarily food and toiletries (47.5\% of migrants' wives reported this expense), followed by children's educational expenses (17.5\%), and medical treatments (16.5\%). ${ }^{182}$ Many migrants' wives also received help from their parents, siblings, or in-laws.

Aside from the economic difficulties that households without remittances face, abandoned wives are at risk for depression, suicide, and physical health problems.

Abandoned families incur strains when they reside with the husband's parents, and "it is not uncommon for women living under such circumstances to encounter abuse and

\footnotetext{
176 Ibid.

177 Definition from Abandoned Wives of Tajik Labor Migrants.

178 Ibid. p. 20

179 Ibid. p. 7.

180 lbid.

181 Tajikistan: The Role and Status of Women in Migrant Households.

182 Abandoned Wives of Tajik Labor Migrants.
} 
violence by their in-laws, or even eviction from the family house." ${ }^{183}$ Abandoned women report that one of the most difficult issues for them is raising children without their fathers. ${ }^{184}$ The psychological impacts of abandonment on children, both boys and girls, are significant, but boys tend to exhibit more aggression and rebellion. ${ }^{185}$ However, boys also face pressures to take on their fathers' role when no remittances are sent and may abandon school in order to work. ${ }^{186}$

Women having limited influence over major household expenditures is significant for any projects that reduce household poverty or encourage redistribution of family budgets (e.g., for girls' education or the adoption of energy-efficient technologies). Several organizations have women's financial literacy projects that include training on budgeting and saving as well as how to use the formal banking system. ${ }^{187}$ The effectiveness of such projects depends on ensuring that women are empowered to make household financial decisions and also that banking institutions are attractive and accessible to them.

\section{Gender Issues in Social Development}

The ability of men and women to participate in and benefit from development projects, especially long term, depends upon such factors as their education, availability, health, and personal security. Though ADB addresses education in Tajikistan, it bypasses time poverty, health care, and GBV. Indirectly, however, these issues can be addressed even in infrastructure projects such as in energy, water resource management, transport, and urban development.

\section{Intrahousehold Gender Dynamics}

The Tajik family structure and the delineation of household gender roles impact how women and girls complete their education, become formally employed or start a business, and participate in community development. The nuclear family model promoted under the Soviet system did not entirely take hold in Tajikistan. Of all the households included in the most recent census (2010), just over $40 \%$ would be considered nuclear families. Approximately $36 \%$ consisted of multigenerational families, the most common pattern being two or more married couples, with or without children, living with other relatives (most typically consisting of an adult couple, their unmarried daughters, and married sons with their wives and children). ${ }^{188}$ Multigenerational families remain common in part because they are traditional, but in large part due to housing shortages, the periodic absence of men due to migration, and the extended family model being efficient for the largely rural population that depends on agriculture.

183 Ibid. p. 26.

184 Situational Analysis Report: the Impact of Migration on the Socio-economic Vulnerability of Rural Women in Tajikistan. p. 34

185 Impact of Labour Migration on Children Left Behind in Tajikistan, p. 98.

186 Ibid. p. 39

187 See, e.g., L. Sconosciuto. 2013. Financial inclusion of remittance recipients in Tajikistan. EBDR Stories. 15 November

188 Women and Men of the Republic of Tajikistan, pp. 8-9. [Russian version] 
Multigenerational families conform to a patriarchal model. Traditionally, a woman joins her husband's extended family at the time of marriage, and " $[\mathrm{t}]$ his system provided little incentive to invest in daughters, since a married woman's contribution accrued to the husband's family rather than to her parents." 189 A young, newly married woman has the lowest family social status, a position that will change once she has children and as she ages. In a survey of 1,500 households, $53 \%$ of respondents either fully or partially agreed with the statement, "a woman's mission is to give birth to children and be a good housewife." 190 Gender roles are rigid and women's lives center around childrearing and domestic tasks, even if they are engaged in formal employment.

According to a 1998 survey, men spent $56.4 \%$ of their work time in paid activity while women spent $72.7 \%$ of their work time in unpaid activity (which equated to 6.3 hours per day). ${ }^{191}$ More recent surveys of women's time used on unpaid activities (from 2003 and 2007) indicate that they spent over 32 hours per week on various household chores and caring for family members. Notably, in the four years between the surveys, the average amount of time that rural women spent on activities such as fetching water, collecting fuel, caring for animals, milking cows, tending family vegetable plots, and preparing meals increased. ${ }^{192}$ The increasing demands on women's time are attributed to "wear and tear and degradation of the housing and communal system," 193 and most likely also reflect an increasing reliance on home-produced goods for subsistence. Although there are no comparable surveys for 2014 , focus group participants who are not formally employed described their daily routines as consisting of household chores, tending family plots and animals, caring for children, and some income-generating activities. Such chores limit women's paid employment, and the resulting lack of formal work history and pension, "increases their economic vulnerability and dependency on other family members,"194 leading to social exclusion.

Responsibility for domestic chores begins at a young age, and many children are engaged in some form of work when not at school. However, research in Khatlon, Sughd, and the Districts of Republican Subordination (DRS) found that girls undertake a greater share of housework than boys. After school, they, "were not allowed to go outside the home to play, but were expected to go straight home and continue with chores," leaving them with less time for recreation than boys. ${ }^{195}$

Women's unpaid work is not considered in national or local economic strategy discussions in Tajikistan. Using gender-sensitive budgeting exercises could, however, estimate the extent to which women work for free. Such exercises could also measure the losses that the nation incurs when women cannot engage fully in paid employment or when their unpaid labor is not factored into the country's development.

189 UNDP. 2010. Human Development Report 2010, The Real Wealth of Nations: Pathways to Human Development. New York. p. 77.

190 The Second Shadow Report on the Realization of the Convention on the Elimination of All Forms of Discrimination against Women by Public Organizations of Tajikistan, p. 22.

191 Women and Men of the Republic of Tajikistan, p. 151. [English version]

192 Women and Men of the Republic of Tajikistan, p. 152. [English version]; and Women and Men of the Republic of Tajikistan, p. 90. [Russian version].

193 UNDP. 2010. National Human Development Report 2008-2009: Employment in the Context of Human Development. Dushanbe. p. 112. 194 lbid.

195 Save the Children. 2011. Child Protection Situational Analysis in Tajikistan. Dushanbe. p. 18. 


\section{Box 3: Empowering or Burdening Women?}

Rural women and girls have limited social, educational, and economic opportunities because of the heavy burdens of domestic work and petty agriculture. Poverty and insufficient remittances also force women to take on additional income-generating activities. Many women-based development projects focus on training and skills needed to earn money through home-based work. However, there is a risk, echoed by an FGD participant in Panjakent, that without measures to redistribute domestic chores more equitably, such initiatives will only add to women's workload.

Oxfam GB has developed a community participatory methodology (Rapid Care Analysis) for assessing women's contribution to unpaid household and care work that it plans to use in Tajikistan. ${ }^{2}$ The methodology could be used to ensure that women benefit from development activities (and are not, in fact, additionally burdened); to gather evidence about gender equality; and to advocate for practical improvements to ease women's workload (which, in the Tajikistan context, could include communal laundries, infrastructure improvements that enable home labor-saving devices, preschools for children, care centers for the elderly, promotion of paternal leave, etc.).

a T. Kidder and C. Pionetti. 2013. Participatory Methodology: Rapid Care Analysis Guidance for Managers and Facilitators. Oxford: Oxfam

Another recurring FGD theme is women's limited role in decision-making and their hampered personal agency. ${ }^{196}$ Women are much more likely to exercise agency around decisions that concern the household and their own lives, but men tend to make decisions about household purchases and work outside the home. Even when women do participate in decision-making, a considerable number do not do so independently. The $2012 \mathrm{TjDHS}$ revealed that more than half of the surveyed women exercised some decision-making concerning their own healthcare, major household purchases, and visits to their own families or relatives, but $34.2 \%$ did not participate at all in any of the decisions. ${ }^{197}$ Husbands and other male members make more decisions than their wives, and men are more likely to take decisions independently than women.

As noted earlier, women's participation in decision-making increases with age, their number of children, and their education level, and correlates with whether they are employed for cash payments. A comparison of women's responses to a similar survey conducted in 2005 unexpectedly found that the proportion of married women who participate in decision-making about their own healthcare and about visits to relatives hardly changed over a seven-year period. The only increase in women's empowerment was seen in the greater number of women reporting that they participate in decisions about large household purchases (from 42\% to 55\%). ${ }^{198}$ This finding should cause concern as it suggests that, despite a large number of state initiatives to raise women's status and development organizations' efforts to empower women, change has been limited. Perhaps assumptions about how best to increase women's agency should be reevaluated and new models applied.

There are few formal barriers to women's participation in public life or community decision-making, but interacting with institutions is considered a "male" role, in part

196 "Women's agency" is a salient concept in feminist social philosophy that refers to the ability to make effective choices and to transform those choices into desired outcomes. "Agency" has become part of the development language of international development organizations to promote gender equality. See, for example, J. Klugman, et al. 2014. Voice and Agency: Empowering Women and Girls for Shared Prosperity. Washington, DC: The World Bank.

197 Tajikistan Demographic and Health Survey 2012, p. 222

198 Ibid. p. 223. 
Figure 7: Participation in Household Decision-Making

(\% distribution)

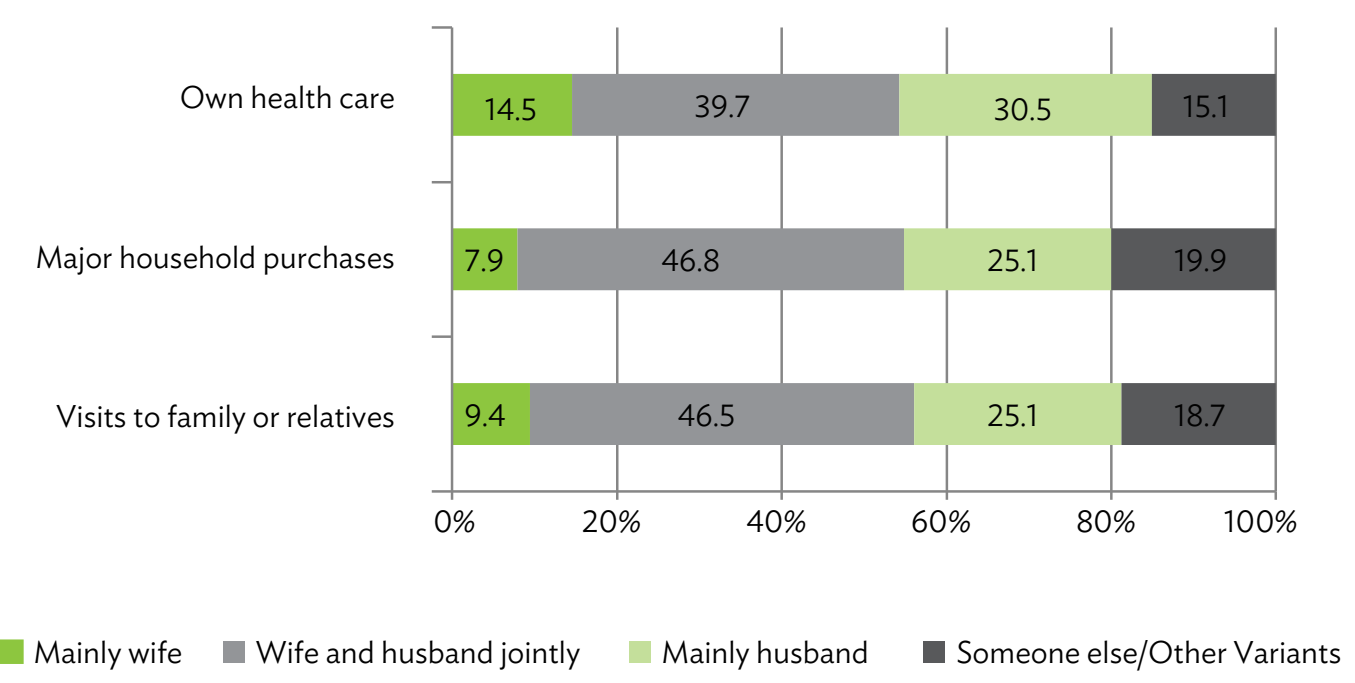

Source: Government of Tajikistan, State Statistics Agency, Ministry of Health and ICF International. 2013. Tajikistan Demographic and Health Survey 2012. Dushanbe, Tajikistan, and Calverton, Maryland. p. 221.

because men lead and work in such structures. So family members discourage women from engaging publicly and avoid such activities themselves. In a study of rural women's involvement in water resource community groups, some female respondents commented that "[w]omen do not travel to government offices," and they "...persuade their men to talk on their behalf." 199 FGD participants also described women's difficulty with expressing public opinions, but not because they prefer to remain passive. Two women from FDGs held in Dushanbe and Garm recounted instances in which they addressed male leaders about community problems and were later subjected to community and family censure. Women's limited interactions with formal institutions impacts not only their ability to influence communities, but also whether they feel confident enough to address government offices and financial institutions when registering a business or applying for loans.

\section{Gender Issues in Health}

The intersections of health and gender are addressed by government gender policy (e.g., the National Strategy for Enhancing the Role of Women in the Republic of Tajikistan for 2011-2020), by health reform projects that focus on maternal health (e.g., the National Action Plan for Safe Motherhood in the Republic to 2014), and by long-term national development strategies (e.g., the Living Standards Improvement Strategy of Tajikistan for 
2013-2015). Notably, gender-sensitive healthcare reform focuses on maternal and child health and women's reproductive health. Among Tajikistan's healthcare priorities are comprehensive access, reducing infectious diseases (especially AIDS and tuberculosis), and developing private services. Low public healthcare spending impacts the entire population, but at the household level, when the family budget is limited, "women's health needs take lowest priority."200

\section{Female Health: Maternal, Reproductive, and Other Physical Health Concerns}

Tajikistan's maternal mortality rate (MMR) has decreased from 48 deaths per 100,000 live births in 2005-2009, to 44 per 100,000 live births in 2010-2014. ${ }^{201}$ The current MMR, however, remains high compared to other countries in Central Asia and the Commonwealth of Independent States. The government acknowledges that official indicators are unreliable, "due to outdated definitions and data collection methods, underreporting and incomplete registration of vital statistics." 202 In terms of improving both maternal and child health, official statistics show that $88 \%$ of pregnant women were receiving antenatal care in 2012 as compared to $70 \%$ in $2008 .{ }^{203}$ The $2012 \mathrm{TjDHS}$ found that $78.8 \%$ of women had received antenatal care at least once from a skilled provider in the five years preceding the survey. ${ }^{204}$

Several preventable factors, often acting in combination, contribute to maternal mortality and poor birth outcomes. These include (i) limited physical and transport access to required medical services, especially in rural areas; (ii) limited human resources and lack of healthcare personnel capacity and skills; (iii) lack of essential equipment; (iv) women's poor health (anemia and hard physical work that women undertake when doing domestic chores, even during pregnancy); and ( $v$ ) women's and family members' low awareness of pregnancy danger signs combined with a reluctance to seek medical care. ${ }^{205}$ These factors also contribute to the prevalence of home births, many of which are carried out in unsafe conditions and are associated with poor health outcomes for both mother and child. Close to a quarter (22.5\%) of all deliveries occur at home, and it is estimated that $60 \%$ of women delivering at home do not receive care during the first six weeks after birth. ${ }^{206}$ Lack of female empowerment may also play a role in the number of home births: FGD participants said that there are cases in which husbands do not allow their pregnant wife to go to a maternity hospital to deliver. However, maternal mortality decreases with increased levels of antenatal care and education. ${ }^{207}$

200 Republic of Tajikistan. 2011. National Strategy for Enhancing the Role of Women in the Republic of Tajikistan for 2011-2020. Article 5.2. Dushanbe.

201 The World Bank. Maternal Mortality Ratio. http://data.worldbank.org/indicator/SH.STA.MMRT. However, data on maternal mortality rate vary by source, from a low of 33.3 deaths per 100,000 live births in 2012 (according to the Ministry of Health) to a high of 65 per 100,000 live births in 2010 (according to the World Health Organization).

202 A. King, M. Rustamova, and K. Sobitov. 2014. UNFPA Tajikistan Country Programme 2010-2015. Evaluation Report. Dushanbe: UNFPA. p. 24.

203 Ibid. p. 47.

204 Tajikistan Demographic and Health Survey 2012, p. 112.

205 Millennium Development Goals, Tajikistan Progress Report, pp. 76-77.

206 Ibid. p. 77

207 Tajikistan Demographic and Health Survey 2012, p. 117. 
Child marriage usually results in early pregnancy in Tajikistan, and most married girls are, "expected to become pregnant and give birth straight after the marriage." ${ }^{208}$ According to the 2012 TjDHS, 7\% of females ages 15-19 have begun childrearing; $4 \%$ had already given birth at the time of the survey, and another $4 \%$ were pregnant with their first child. ${ }^{209}$ Childbearing at an early age "has a major, negative effect on both the mother and the child's health."210

Very few women begin to use contraception before they have had at least one child, and sexually active adolescents are much less likely to use modern forms of contraception than older women. Young people in Tajikistan face barriers in accessing sexual and reproductive health (SRH) services, such as lack of family planning services in rural areas, lack of income, and parental consent requirements. Because virginity is highly valued, especially for girls, and early sexuality is taboo, it is "difficult for young people to talk to adults or access information and services." 211 Moreover, youth perceive existing services as insufficiently confidential, and they prefer health care providers who are themselves young and of the same sex. ${ }^{212}$ Young women and girls in Rasht Valley, in particular, are deterred from visiting medical facilities due to the lack of female nurses and doctors. ${ }^{213}$ It is also significant that condoms are sometimes provided for free, but contraceptive pills are not. Given women's lack of empowerment in many contexts in Tajikistan, female adolescents may not be able to negotiate with a partner to use condoms; thus, providing low-cost birth control options to women would be useful. FGD participants to this assessment drew attention to young people's lack of basic education on sexual health and hygiene and reproduction, and they recommended introducing school courses oriented to preparing for family life.

Over a quarter of currently married women are using some form of contraception (primarily, the IUD), but female contraceptive use has declined in the last decade from $38 \%$ in 2005 to $28 \%$ in $2012 .{ }^{214}$ Despite the availability of modern contraception methods, there are still unmet needs in terms of family planning and SRH services. The decline in contraception use could be a function of extended migration: married women who report that their husband or partner live elsewhere are less likely to use contraception than those who live with their husbands (17\% and $29 \%$, respectively, using any form of contraception). Still, given that the overall number of women whose husbands live elsewhere is small (7\% of surveyed married women), "the behavior of this group is unlikely to have had a very major effect on the trend in contraceptive use." 215

SRH services are important, not only for family planning, but also preventing sexually transmitted infections (STIs), especially HIV. At the end of 2013, there were 4,581 people living with HIV in Tajikistan (69.8\% male and 30.2\% female). ${ }^{216}$ The epidemic has manifested itself differently among men and women. Men with HIV are generally

\footnotetext{
208United Nations Population Fund (UNFPA). 2014. Child Marriage in Tajikistan. p. 2. http://eeca.unfpa.org/publications/child-marriagetajikistan-summary.

209 Tajikistan Demographic and Health Survey 2012, p. 66

210 Child Marriage in Tajikistan, p. 3.

211 M. Colombini, S. Mayhew, and B. Rechel. 2011. Sexual and Reproductive Health Needs and to Services for Vulnerable Groups in Eastern Europe and Central Asia. London School of Hygiene and Tropical Medicine/United Nations Population Fund. p. 8. 212 Ibid.p. 42

213 Gender and Youth Study in Rasht Valley, p. 22

214 Tajikistan Demographic and Health Survey 2012, p. 78

215 Ibid. p. 82.

216 Joint United Nations Programme on HIV/AIDS. 2014. Country Report on Progress in Preventing the HIV Epidemic. Tajikistan. p. 8. [in Russian] http://www.unaids.org/sites/default/files/country/documents//TJK_narrative_report_2014.pdf.
} 
between $30-39$ years old (46.4\% of the male HIV-positive population), while women are younger: $42.4 \%$ of women with HIV are ages 19-29. The most common transmission route for women is through sexual contact ( $80 \%$ of cases), while men are almost equally likely to become infected through sexual contact (43\% of cases) and injecting drugs ( $42 \%$ of cases). ${ }^{217} \mathrm{HIV}$ still disproportionately impacts the male population, but the proportion of women among new confirmed cases has been increasing from $25.9 \%$ of new cases in 2009 to $39.4 \%$ in 2013 (the figure is higher when considering only women of reproductive age). ${ }^{218}$ Outreach to at-risk groups has addressed the disease's spread, but a closer examination of the complex and gender-specific risk factors for HIV infection is also essential.

Male labor migration is closely associated with an increased risk of STIs and it can serve as a transmission bridge to the country of origin. A study of Tajik male migrants living in Moscow found that they had high rates of unprotected sex with prostituted women, multiple concurrent partners, and low condom use, especially when drinking alcohol. ${ }^{219}$ The specific working and living conditions of the labor migrants, "tend to amplify some masculine norms that are associated with higher HIV sexual risk." 220 Men are far more likely to be injecting drug users (IDUs) than women (for example, in 2008, 95\% of registered drug users in Tajikistan were male; almost two-thirds were IDUs). ${ }^{221}$ Men who have sex with men are also at risk for HIV, but they remain quite an isolated group in terms of outreach and service provision due to widespread stigma and discrimination.

Those especially vulnerable to HIV infection are wives and sexual partners of labor migrants and IDUs, persons in prostitution (most of whom are female), IDUs themselves, and the spouses of married men who have sex with men. ${ }^{222} \mathrm{~A}$ small study of migrants' wives (30 women) revealed the complex gender dynamics behind the HIV epidemic. Migrants' wives were aware that their husbands were engaged in extramarital affairs, but "believed they had no choice but to accept it."223 Because of commonly accepted stereotypes about men as leaders and providers, the wives trusted their spouses to take precautions and protect themselves against HIV and generally did not ask their husbands to use condoms. In comparison, the 2012 TjDHS found that $58 \%$ of women believed that a wife is justified in asking her husband to use a condom if she knows that he has an STI. However, even within this group, there is significant variation by age: only $25 \%$ of married women between 15-19 agreed with the statement. ${ }^{224}$ The migrants' wives reported basic knowledge of HIV and AIDS, mainly gained through media programs, but also that they were "discouraged from having knowledge about sexuality and HIV/AIDS", or are reluctant to voice concerns with their husbands because it could be understood as a sign of infidelity or they fear provoking anger or violence. ${ }^{225}$

217 Ibid. pp. 9, 11.

218 Ibid. pp. $10,14$.

219 S. Weine, M. Bahromov, S. Loue and L. Owens. 2013. HIV Sexual Risk Behaviors and Multi-Level Determinants Among Male Labor Migrants from Tajikistan. Journal of Immigrant and Minority Health. 15 (4). pp. 700-710. http://www.ncbi.nlm.nih.gov/pmc/articles/ PMC3789367/

$220 \mathrm{lbid}$.

221 UNODC. https://www.unodc.org/docs/treatment/CoPro/Web_Tajikistan.pdf

222 Centre for Mental Health and HIVAIDS, Tajik Network of Women Living with HIV and Guri Surkh. 2013. Alternative Report on Implementation of the UN Convention on the Elimination of All Forms of Discrimination against Women. Dushanbe. p. 5.

223 A. Golobof, S. Weine, M. Bahromov and J. Luo. 2011. The Roles of Labor Migrants' Wives in HIV/AIDS Risk and Prevention in Tajikistan. AIDS Care. 23 (1). pp 91-97. http://www.ncbi.nlm.nih.gov/pmc/articles/PMC3816794/

224 Tajikistan Demographic and Health Survey 2012, p. 179.

225 The Roles of Labor Migrants' Wives in HIV/AIDS Risk and Prevention in Tajikistan. 
The prevalence of HIV among prostituted women in Tajikistan is estimated at $4.4 \%$ (there are an estimated 6,000 prostituted women in Dushanbe). ${ }^{226} \mathrm{~A}$ sample of 100 prostituted women reported consistent condom use with commercial partners, but they were much less likely to use condoms with regular partners, which puts them and their partners at risk for STIs. In contrast to the migrants' wives who were never tested for HIV (and some were not aware of the existence of such testing), $95 \%$ of prostituted women reported having been tested in the last 12 months ( $99 \%$ also reported receiving pre- and/or posttest counseling). ${ }^{227}$ It appears that outreach programs aimed at some at-risk groups have positively impacted behavior, although prostituted women report incidents of violence and discrimination. Further efforts are needed to reach the larger and more diverse population of women in relationships with labor migrants who do not feel empowered to discuss safe sex with their partners and who have limited knowledge about STI transmission.

\section{Box 4: Women Living with HIV}

In addition to the issues that all persons living with HIV face, women living with HIV are often subject to economic insecurity and discrimination from their families, service providers, and society at large. A survey of 230 women living with HIV found that almost half were married (either officially or unregistered) and close to a quarter were widowed. ${ }^{2}$ Two-thirds were financially dependent on their husbands or relatives. Based on an analysis of their monthly income, most (76.6\%) would be categorized as poor; of this group, more than half-59.2\% - were in extreme poverty. Almost all of the women (89\%) had children, almost half of whom were under age five. ${ }^{b}$

The psychological burden of living with HIV is heavy, and women report feelings of fear (of disclosing their status, for example), shame, guilt, and depression. Women living with HIV who participated in interviews, many of whom were infected by their husbands, consider themselves responsible for the situation, and the majority had suicidal thoughts. ${ }^{c}$ Women living with HIV are often subjected to abuse and reproach from their husbands' families, and in cases where their husbands' statuses are not disclosed, women can be stigmatized and isolated within the household or kicked out of their homes. Even if they are aware of their rights, women will rarely claim marital property since a legal process could mean that their status would no longer be confidential. Likewise, the need to present official status documents in order to receive certain social benefits and for employment further isolates women living with HIV.

a UNAIDS. 2013. Research on Identifying the Needs and Problems of Women Living with HIV in Tajikistan. Dushanbe. p. 12. [in Russian]

b lbid. p. 14

Centre for Mental Health and HIVAIDS, Tajik Network of Women Living with HIV and Guri Surkh. 2013. Alternative Report on

Implementation of the UN Convention on the Elimination of All Forms of Discrimination against Women. Dushanbe. pp. 11-12.

Cancer is still another significant health concern for women. Improving prevention, detection, and treatment of cancer in women has been highlighted as a priority area by the Government of Tajikistan. Very few women have examinations for breast or cervical cancers (only $3 \%$ of women reported ever having a breast exam from a healthcare provider, and only $8 \%$ had had a pap test). ${ }^{228}$ The United Nations Population Fund (UNFPA) facilitated a national action plan on cervical cancer prevention that the Ministry of Health accepted and began to implementing 2014 with donor support. ${ }^{229}$

\footnotetext{
226 Central Asia Republics (2012): HIV and TB TRaC study understanding risk behaviors associated with HIV transmission and utilization of HIV prevention services among SWs in Almaty (Kazakhstan), Chui Oblast (Kyrgyzstan), and Dushanbe (Tajikistan), p. 8.

227 Ibid. p. 22; and The Roles of Labor Migrants' Wives in HIV/AIDS Risk and Prevention in Tajikistan.

228 Tajikistan Demographic and Health Survey 2012, pp. 125, 127.

229 The donors are USAID and the Aga Khan Foundation. UNFPA Tajikistan Country Programme 2010-2015. Evaluation Report, p. 24
} 
When women are asked about specific personal medical care barriers, the most common problems are: getting money for advice and treatment (cited by $44.5 \%$ of women); distance to a health facility (29.1\%); not wanting to go to the facility alone (26\%); and getting permission to go for treatment (17.1\%). ${ }^{230}$

\section{Psychological Health}

Between 2008 and 2010, suicides among people aged 15-19 increased from 2.8 per 100,000 to 4.5 . The female suicide rate at this time increased $176 \%$ (from 1.9 to 5.2 per 100,000 ), while the male suicide rate increased by only $6 \% .{ }^{231}$ Although the reported Tajikistan suicide rate remains low compared to other Central Asian countries, the perceived increase was alarming and initiated a discussion about the status of mental health among young people and girls in particular. An in-depth study of youth suicide dynamics found that at-risk girls have lower levels of education than those in a control group. Other factors include forced marriage, experience of domestic violence or family conflict, and being, "blamed unjustly." ${ }^{32}$ FGD participants, especially in Sughd viloyat, drew attention to psychological family pressures, leading young women to despondency and isolation, especially newly married women. Such pressures are also associated with female suicides.

Psychological pressure for men comes from the burden of fulfilling the traditional breadwinner role in the context of high poverty levels and limited employment opportunities. Respondents to this assessment described young men being pressured to migrate since most males in their villages are also migrants. Psychological pressure also rests on the large number of migrant men who have been banned from re-entering the Russian Federation, so that their ability to provide for their families is compromised, which negatively impacts their mental health and propensity to domestic violence. Men's greater propensity to unhealthy behaviors, such as alcohol abuse, smoking, and use of chewing tobacco, impact their overall well-being and is also closely linked to poor stress management. Young men are more likely to attempt or complete suicide due to physical illness or injury, debt, and family conflicts.

Both service providers and family members, "indicated high levels of shame and an expectation of punishment associated with suicidal behavior." 233 Stigmatization of psychological health issues, and underdeveloped services, means that people are reluctant to seek assistance. Crisis centers and resource centers that offer psychological counseling may be one of the more accessible options for women, but may not be effective options for men (it should be noted, however, that men made up almost $10 \%$ of people who applied to crisis centers from 2010-2011, but it is not known what reasons they presented). ${ }^{234}$

230 Tajikistan Demographic and Health Survey 2012, p. 130

231 UNICEF. 2013. Study of Prevalence and Dynamics of Suicide among Children and Young People (12-24 Years of Age) in Sughd Region, Tajikistan. Dushanbe. pp. 2-3.

232 lbid. pp. 21-25.

233 lbid.

234 The Second Shadow Report on the Realization of the Convention on the Elimination of All Forms of Discrimination against Women by Public Organizations of Tajikistan, p. 12. 


\section{Gender-Based Violence}

Domestic violence, including intimate partner violence, is the most common form of gender-based violence (GBV) that is linked to a patriarchal system. In Tajikistan, domestic violence is largely considered a private matter and best resolved within individual families. The adoption of the Law on the Prevention of Domestic Violence (2013) and subsequent State Program for the Prevention of Domestic Violence for 2014-2023 sent the powerful message that domestic violence is not a private matter, but a social issue in which the state should intervene. The domestic violence law addresses physical, psychological, sexual, or economic harm committed within a family relationship and identifies perpetrators and victims as any family members, not just spouses. ${ }^{235}$ Domestic violence is not only a violation of the human rights of the victims/survivors (who are disproportionately female), but also impedes their enjoyment of other rights and has serious repercussions for the family, especially children, and society as a whole. Implementation of the law has been a challenge, however, and experts point out its inadequacies, such as the lack of a referral mechanism, system of coordination, or response protocols. It is hoped that a legal commentary to the law, drafted in November 2014, will clarify dealing with domestic violence cases.

Estimates on the prevalence of domestic violence range from one-third to one-half of women in Tajikistan having regularly experienced physical, psychological, or sexual violence. ${ }^{236}$ The 2012 TjDHS represents the largest sample of women ever asked about personal experiences of domestic violence in Tajikistan (more than 4,400 women). Of ever-married women (ages 15-49), almost one in five reported having experienced emotional, physical, or sexual violence from their husband (19\%); 13\% of those who had experienced physical violence reported that an incident had taken place within the last 12 months, and $4 \%$ of women disclosed that they had experienced sexual violence at least once. 237 The TjDHS did not include questions about "economic violence," which refers to control over income and expenditures, prohibitions on making decisions about the family budget and employment, and debt bondage, but an NGO-managed database shows that women independently experience economic violence slightly more of ten than physical violence. ${ }^{238}$ Among women who turn to NGO centers for assistance, most have experienced psychological violence, followed by multiple forms of violence (almost a quarter of women in 2011). ${ }^{239}$ Of women who have experienced physical or sexual violence, over a quarter report that they suffered some form of injury (mainly cuts and bruises as a result of pushing and slapping). ${ }^{240}$ Nineteen percent of women said that they had experienced three or more forms of control by their husbands, most commonly manifestations of anger, possessiveness, and jealousy (if they spoke with other men, for example), and isolation (insisting on knowing where the wife is at all times and not permitting her to meet even female friends). ${ }^{241}$ Crisis centers and experts on domestic violence also report a specific form of violence: driving women to suicide.

235 Article 1, Law on the Prevention of Domestic Violence.

236 Violence is Not Just a Family Affair. Women Face Abuse in Tajikistan, p. 13.

237 Tajikistan Demographic and Health Survey 2012, p. 193.

238 The Second Shadow Report on the Realization of the Convention on the Elimination of All Forms of Discrimination against Women by Public Organizations of Tajikistan, p. 12.

239 Ibid.

240 Tajikistan Demographic and Health Survey 2012, p. 209

241 Ibid. p. 201. 
There is no profile of a "typical" victim/survivor of domestic violence in Tajikistan, since women in all demographic categories report experiencing violence. However, girls who are underage when married are thought to be especially vulnerable to domestic violence. Six of eight women married as children under a UNFPA study reported violence in the marriage. ${ }^{242}$ Current husbands/partners and former husbands/partners are the most likely to use physical violence against their wives (90.9\% of women named husbands or partners as perpetrators). ${ }^{243}$ Women's advocates who work with violence survivors describe the role of the mother-in-law, and, less often, other in-laws, in exerting psychological pressure on daughters-in-law, including humiliation, controlling behaviors, isolation from friends and family, and other forms of harsh treatment, and encouraging their sons to use violence against their wives. There are, however, mothers-in-law who are reported to use physical violence on their young daughters-in-law (1.6\% of surveyed women).

Women's resource and crisis centers operating throughout Tajikistan report that the most common spurs to consultations and assistance are "violent actions as threats, insults, personal mild and moderate injuries, beating." 244 They also report that the vast majority of women who seek assistance do so only after repeated incidents of violence, which indicates the many obstacles to protecting their rights. Of women who have experienced physical or sexual violence, only $20 \%$ took some steps to stop it, $10 \%$ never sought help, but told someone about it, and $61 \%$ never sought help, nor told anyone about it. ${ }^{245}$ Survivors who are employed and those with professional primary or secondary education are more likely to seek help. ${ }^{246}$ Of those who did seek help, most turned to their own families (74\%), followed by their husbands' families (36\%), and very few approached the police (4\%). ${ }^{247}$

Several factors complicate finding assistance, but primary among them is that "many women are conditioned or pressured to remain silent under abusive conditions and made to believe that reporting violence would contravene societal values." 248 A 2005 survey carried out among 600 residents of Khatlon viloyat found that $70 \%$ of female respondents believed a husband has the right to beat his wife when he is angry (compared to $30 \%$ of male respondents), and $60 \%$ of women agreed that a husband has the right to forbid his wife from leaving the house (compared to $42 \%$ of male respondents). ${ }^{249}$ Female participants in the TjDHS felt that a husband is justified in hitting his wife most often in the following scenarios: she goes out without telling him (51\% agreed); she neglects the children (44\%); and, she argues with him (40\%). Just over a quarter of women felt that refusing to have sexual intercourse or burning food justifies domestic violence. ${ }^{250}$ Although these findings indicate that further efforts are needed to overcome women's acceptance of domestic violence, a comparison of TjDHS responses to those received in 2005 indicates that acceptance for wife beating has declined among women. Women's financial dependency on their husbands is also a considerable disincentive to reporting violence. Even in cases of registered marriages, divorce or separation can have serious financial consequences for a woman. In the absence

242 Child Marriage in Tajikistan. p. 3.

243 Tajikistan Demographic and Health Survey 2012, p. 197.

244 The Second Shadow Report on the Realization of the Convention on the Elimination of All Forms of Discrimination against Women by Public Organizations of Tajikistan, pp 46-46.

245 Tajikistan Demographic and Health Survey 2012, p. 213.

246 lbid.

247 Ibid.

248 United Nations Human Rights Council. Report of the UN Special Rapporteur on violence against women, its causes and consequences. Mission to Tajikistan. 2009. para. 38.

249 Violence is Not Just a Family Affair. Women Face Abuse in Tajikistan, p. 14

250 Tajikistan Demographic and Health Survey 2012, p. 224 
of viable alternatives to married life, for many women, complaining to the police or initiating a divorce in cases of domestic violence is unthinkable.

\section{Box 5: Support for Women Survivors of Gender-Based Violence}

Assistance to gender-based violence (GBV) survivors is provided by both the state and civil society. The Women's Committee operates two specialized centers (the "Bovari" center for women a and the "Charogikhidoyat" support center for girls aged 10-18), as well as community-based information-consultation and crisis centers. ${ }^{b}$ The Dushanbe hukumat supports the Center for Women's Self-Knowledge that provides counseling and assistance for a variety of women's issues. NGOs throughout the country operate 18 women's centers that provide counseling to women in times of crisis, including in cases of domestic violence. These organizations are geared to preparing and disseminating awareness-raising materials, operating telephone hotlines, and providing psychological and legal counseling. There are no uniform domestic violence care or service provision standards, so the type and quality of institutional assistance can vary.

Three temporary shelters operate in Tajikistan: one within the Girls Support Center, and a shelter for female trafficking victims (both in Dushanbe), along with an NGO-managed shelter in Khujand (financed by donors and now also with funds from the local budget). An additional Dushanbe shelter initiated by the United Nations Population Fund (UNFPA) in 2012 is intended to be the first specialized long-term shelter in the country. It is expected to also receive municipal funds and begin operation in early $2015 .^{\mathrm{C}}$ In cooperation with the Ministry of Health, UNFPA also piloted the creation of eight victim support rooms in state maternity hospitals that can also offer women a temporary ("post-shock") place to stay. In 2010, the Ministry of Internal Affairs introduced five specialized police units (two in Dushanbe and one each in Khujand and Kurgan-Tyube) that are staffed with female inspectors and operate from dedicated rooms. ${ }^{d}$

The donor community also supports such anti-domestic violence activities as the dissemination of information about the new law, community-based awareness-raising with varied stakeholders (including male religious and mahalla leaders), legal services and mediation, and public advocacy campaigns (such as the 16 Days of Activism Against GBV).

a In 2013, the Bovari center re-registered as an NGO. It is still under the auspices of the Women's Committee, but is supported primarily by donor funds.

b Government of Tajikistan. 2014. National Review of the Republic of Tajikistan to Implement the Beijing Declaration and Platform for Action. p. 21.

c A. King, M. Rustamova, and K. Sobitov. 2014. UNFPA Tajikistan Country Programme 2010-2015. Evaluation Report. Dushanbe: UNFPA. p. 59.

d The Organisation for Security and Co-Operation in Europe supports the units and has trained the police officers.

Available services are insufficient to meet the complex needs of survivors of violence, especially in terms of temporary housing. ${ }^{251}$ The hospital-based support rooms, for example, are, "under-utilized" due to "deeply engrained cultural norms and insufficient knowledge about the [facilities] among women and actors working in the area of women's rights and GBV." 252 It was also found that health personnel were insufficiently qualified in victim referrals. However, the "medical model" is viewed as more appropriate for the Tajik context, as opposed to the free-standing domestic violence shelter that is common in Europe and the US. In visiting the latter type of shelter, women would face considerable scrutiny and stigma for leaving her husband's home, whereas seeking "medical treatment" would be viewed as acceptable and could help survivors overcome inhibitions.

251 The Council of Europe recommends the following core minimum standards for services: one place in a shelter per 10,000 population (this may include a family place for women with children); at least one specialist shelter for women survivors of violence in every region; one rape crisis center per 200,000 women; and one sexual assault center for 400,000 women.

L. Kelly and L. Dubois. 2008. Combating Violence Against Women: Minimum Standards for Support Services. Strasbourg: Council of Europe.p. 38.

252 UNFPA Tajikistan Country Programme 2010-2015. Evaluation Report, pp. 56-58. 
Other forms of GBV are more latent than domestic violence. Tajikistan is a country of origin for trafficked men, women, and children into situations of forced labor (mainly to the Russian Federation and the UAE), and/or sexual exploitation (primarily to the Russian Federation, the UAE, Turkey, Kazakhstan, and within Tajikistan). Reliable data about the scale or forms of human trafficking is scarce and generally not sex-disaggregated. In 2013, the government identified 17 trafficking victims and referred them to assistance. In the same period, NGOs provided assistance to 67 trafficking victims (48 victims of forced labor and 19 victims of trafficking for sexual exploitation). ${ }^{253}$ The trafficking of men is closely associated with labor migration, while the trafficking of women is of ten for sexual and labor exploitation. One study of trafficking shows that almost all male victims were married, but most female victims were unmarried or divorced. ${ }^{254}$ Women are vulnerable to trafficking especially, "after they are informally divorced from their absent migrant husbands and then need to provide for their families." 255 Specific push factors for women to fall victim to human trafficking include labor market inequalities, domestic violence and isolation, lack of social protection, and low educational qualifications. ${ }^{256}$

Human trafficking experts from the US Department of State assessed Tajikistan's prevention and prosecution efforts as inadequate despite a 2004 law, a governmental interagency commission, and several policy documents (e.g., two state programs for 2006-2010 and 2011-2013, and regulations on service provision to victims). ${ }^{257}$ There has also been no clear mapping of at-risk populations, the gender-based risk factors, or traffickers' methods and transit corridors. Identification of victims has been weak, and there is no national referral mechanism. In cases of sex trafficking, law enforcement frequently penalized victims for prostitution crimes. Migrants experiencing labor trafficking or exploitation generally make complaints about private employment agencies. ${ }^{258}$ Due to limited law enforcement and judicial actor capacity, cases of human trafficking are frequently not properly identified; in some instances, victims are dissuaded from pursuing criminal charges. Government funding does not extend to NGOs that assist victims. ${ }^{259}$

Sexual harassment is another cited form of GBV, but neither relevant statistics, nor survey data, nor research were uncovered in the course of carrying out this assessment. The US Department of State maintains that victims do not report incidents because of fear of social stigma, and those that do have, "faced retaliation from their employers as well as disgrace from their families and communities." 260 There is no specific legislation on sexual harassment, although some acts may fall under criminal provisions. Authorities are said to have little understanding of sexual harassment and may either conflate it with sexual exploitation of minors or perceive it as merely "female fabrications."

253 US Department of State. 2014. Trafficking in Persons Report. Washington, DC. p. 370.

254 S. Olimova and M. Mamagzhanova. 2006. Trafficking in Persons in Tajikistan. Dushanbe: International Organization for Migration (IOM) and Sharq Research Center:. p. 38. [in Russian]

255 Trafficking in Persons Report, p. 369.

256 Trafficking in Persons in Tajikistan, pp. 16-18. [in Russian]

257 Trafficking in Persons Report, p. 370.

258 Human Rights Center. 2013. Submission to the 108th Session of the UN Human Rights Committee. Dushanbe. p. 3.

259 Trafficking in Persons Report, p. 370.

260 US Department of State. 2013. Country Reports on Human Rights Practices for 2013: Tajikistan. Washington, DC. http://www.state.gov/j/ $\mathrm{drl} / \mathrm{rls} / \mathrm{hrrpt} /$ humanrightsreport/index.htm? year=2013\&dlid=220406 261 lbid. 


\section{Women's Access to Justice}

Analyzing women's access to justice involves considering both the functioning of the legal system and remediation. In Tajikistan, many of the barriers that women face are cultural, rather than legal. Ensuring that women can realize de facto guarantees of equality is a significant challenge for the nation.

The most frequently cited barrier to women accessing justice is their reduced legal literacy. In fact, research shows that citizens on the whole have a poor understanding of their rights and very rarely exercise them to resolve legal problems (a survey of individuals in Tajikistan revealed only $2 \%$ of respondents had used the court system in the last five years). ${ }^{262}$ An interviewee with experience of legal awareness programs stated that many women do not understand their rights, but for them, "having bread and a roof over their heads is enough." A detailed survey of 1,300 women and girls, conducted under an ADB pilot project in four districts of the Rasht Valley demonstrated that women's knowledge of their rights concerning issues that impact them the most is particularly limited. ${ }^{263}$ When asked generally what rights women have in Tajikistan, $80 \%$ of respondents were unable to answer. At the same time, $52 \%$ of respondents thought that men have more rights than women due to their status as heads of household. Responses to more targeted questions revealed limited understanding of the legal protections that they enjoy: $42 \%$ did not know the meaning of an employment contract, and $87 \%$ did not know of any employment benefits to which they were entitled. Lack of labor rights knowledge may be a reflection of few of the respondents being formally employed. In terms of family life, most women (58\%) understood that legal marriage requires civil registration, but $42 \%$ believed it was sufficient for a mullah to conduct the marriage ceremony. ${ }^{264}$ Thirty-eight percent did not know the meaning of "joint marital property," and 62\% believed that the religious practice of the husband pronouncing "talaq" three times constitutes a legal divorce. Other specific groups of women who lack access to information or have lower levels of education, such as those with disabilities or from ethnic minority groups, are likely to have limited knowledge of their rights.

Beginning from childhood, women's and girls' lack of legal status is a significant impediment to protecting their rights. Just under $12 \%$ of children age five or less have no birth registration; this figure varies by region, with Dushanbe and DRS having the lowest number of registered births (around $86 \%$ ). ${ }^{265}$ There is a very slight variation in the number of girls and boys whose births are registered ( $89 \%$ of boys and $87.8 \%$ of girls), with no clear evidence that gender discrimination plays a role here. However, FDG participants did suggest that parents may be more attentive to registering the birth of a boy because they know he will eventually have to perform military service or may apply for a passport. FDG participants in Garm outlined a typical scenario that prevents a child's birth from being registered: the mother delivers at home and cannot travel to the district center registry office, so she waits for her migrant husband to return, which is often after the three-month

262 Eurasia Foundation and Caucasus Research Resource Centers. 2011. Equal Before the Law? A Study of How Citizens Experience Access to Justice in Kazakhstan, Kyrgyzstan and Tajikistan. Washington, DC. pp. 24, 28.

263 ADB. 2014. Report on survey conducted among women and girls of Rasht region and District Task Force rapid needs assessment. Manila

264 Of note, three-quarters of respondents to another survey did not know that marriage carried out only by a religious leader is not recognized by the state. Equal Before the Law? A Study of How Citizens Experience Access to Justice in Kazakhstan, Kyrgyzstan and Tajikistan, p. 7.

265 Tajikistan Demographic and Health Survey 2012, p. 25 
registry period has passed. Lack of proper registration denies children legal status and means they cannot claim their right to education or social benefits. Furthermore, lack of birth certificates greatly complicates the task of regulating under-age marriage.

While prohibited by law, early marriages (before age 18), forced marriages, and polygamous marriages occur in Tajikistan. Because such marriages are not legal, they are performed using the Muslim rite of "nikoh." Many couples that are of age and monogamous also marry with only a religious ceremony. It has been suggested that a 2011 law restricting marriages between Tajik citizens and foreigners has pushed more people into marrying through nikoh, especially in communities that border Uzbekistan and the Kyrgyz Republic. ${ }^{266} \mathrm{~A}$ marriage that is not legally recognized does not confer rights to either spouse, but in Tajikistan the impact is much greater on women who are financially dependent on their husbands, especially if the marriage is dissolved or the husband dies.

The official divorce rate increased 1.3 times from 2010-2013 to one in every 14 marriages. ${ }^{267}$ Experts believe that the actual rate is higher given the rise in divorces initiated by men repeating "talaq" (very often conveyed by migrant husbands via telephone or SMS text). ${ }^{268}$ Talaq refers only to a religiously recognized dissolution of marriage, but it can initiate a legal divorce that is registered in the civil registry office. For women in unregistered marriages, divorce initiated by "talaq" is sufficient grounds for her in-laws to evict her, and she would have no legal rights to claim joint property or child support. Even in cases of legal marriage and divorce, women's marital property rights are often violated. According to custom, women are also not considered to have moveable household property rights. It is common for property to be registered in the husband's name only, or in the name of the father-inlaw. Research carried out in Khatlon viloyat to examine women's property ownership found that $82 \%$ of divorced women did not receive any housing under the settlement, but instead returned to their parents' home or lived with relatives. ${ }^{269}$ An interviewee to this assessment did note that in the last five years, judicial protection of women's rights has improved somewhat and judges not infrequently require husbands to provide a separate apartment or room where the former wife can live with the children.

In the absence of a legally recognized marriage or birth certificate, it is particularly complicated to establish paternity in order to obtain child support (note that "alimony" in Tajikistan is for children and there is no payment for spousal maintenance). Even when women have been successful in securing alimony, they often do not receive any payments due to their former husbands being labor migrants and their locations often not being known. It appears that there are no reciprocal agreements with the Russian Federation regarding alimony, and that courts routinely put the onus of finding the husband on the ex-wife-a task that is extremely difficult, especially for women in rural areas with limited education and resources.

Gender-neutral barriers to justice disproportionately impact women due to their disadvantaged position. There are few practicing attorneys in Tajikistan, and most are

266 E. Shoshina. 2013. Tajik Marriage Reform Misfires. Institute for War and Peace Reporting. 26 July. https://iwpr.net/global-voices/tajikmarriage-reform-misfires.

267 Women and Men of the Republic of Tajikistan, p. 34.

268 In 2011, the State Committee on Religious Affairs prohibited divorce via SMS, but the practice remains common. M. Hasanova. 2011. In Tajikistan, divorce by SMS will be abolished. Asia Plus. 12 April. http://news.tj/ru/news/v-tadzhikistane-budut-otmeneny-razvody-posms.

269 Trafficking in Persons in Tajikistan, p. 17. 
concentrated in urban centers (there are 10 attorneys per 100,000 population; half of all practicing lawyers are located in Dushanbe). ${ }^{270}$ Constraints on women's mobility and time mean that they are isolated from professional legal services, if they can even afford to hire a private attorney. Free legal assistance is still nascent in Tajikistan. In addition to financial and other constraints, a lack of trust in formal justice mechanisms underpins women's inaction in protecting their rights. Of surveyed women, $10.4 \%$ did not exercise their rights because they believed nothing would change. ${ }^{271}$ Women are much more likely to approach elder relatives and friends or the mahalla chairperson for legal advice than they are to turn to specialists. Social pressure also restrains women from fully protecting their rights. In rural areas especially, women are "prevented from seeking access to their rights by constraints placed on them by family members and the community."

The adoption of the 2013 Law on the Prevention of Domestic Violence has the potential to greatly expand protections for domestic violence survivors. The law introduces three specialized remedies: a type of official warning, the protective order, and administrative arrest. Crucially, the law does not define a mechanism for implementing these remedies. There has been no monitoring of how the law is being used. It is also unclear to what extent the protection order and administrative arrest will be either accepted by society or favored by domestic violence survivors. Given the typical family dynamic in which wives live with their husband's family and mothers-in-law are seen as perpetrators of psychological violence, it seems possible that survivors will face greater pressure not to report domestic violence. The law focuses on perpetrators of domestic violence and does not articulate rights of survivors (e.g., rights in civil suits, guarantees of free legal aid, restitution, etc.). Several organizations are addressing women's rights awareness and the domestic violence law, but a more comprehensive approach is needed that includes improving law enforcement and legal system GBV responses.

The jurisprudence of sex-based discrimination claims is not well developed in Tajikistan, and judges have very limited experience applying either domestic or international legal norms in such cases. More than half (57\%) of judges involved in a survey on legal system gender sensitivity answered that they had heard cases concerning violations of the rights and freedoms of women and girls, whereas just over a quarter (27.8\%) had considered cases concerning the rights and freedoms of men. ${ }^{273}$ However, when asked about their experience applying specific laws, only $11.2 \%$ had relied on the Law on State Guarantees of Equal Rights and Opportunities for Men and Women for the protection of women's rights, though $19.6 \%$ used it in cases concerning men's rights. Only $7 \%$ of judges applied the provisions of CEDAW (in cases involving women or men), and the majority of judges relied only on basic legislation, that is, the Family Code, Criminal Code, and Labor Code, which have limited discrimination provisions.

\footnotetext{
270 M. Gramatikov and M. Kabir. 2013. Accessing Justice: Legal Aid in Central Asia and the South Caucasus. Bratislava: UNDP Regional Centre for Europe and the CIS. p. 26.

271 ADB. 2014.TA 6143 Promoting Gender Equality and Women's Empowerment: Training and Awareness-Raising for Rural Women on Rights, Family Law, and Access to Legal Assistance. Consultant's Report. Manila.

272 Equal Before the Law? A Study of How Citizens Experience Access to Justice in Kazakhstan, Kyrgyzstan and Tajikistan, p. 13.

273 League of Women Lawyers of the Republic of Tajikistan. 2012. Short Survey on Implementation of Gender-Sensitive Law by Judges in Selected Regions. Dushanbe: Committee on Women's and Family Affairs. p. 13. [in Russian].
} 


\section{Mainstreaming Gender in Project Operations}

The Asian Development Bank (ADB) Policy on Gender and Development adopts mainstreaming as a key gender equity and women's empowerment strategy. ${ }^{274}$ ADB's long-term strategic framework, Strategy 2020, identifies gender equity as one of the five "drivers of change (that is)... essential to poverty reduction, improved living standards, and sustainable economic growth." 275 The ADB approach to gender and development, and specifically to gender equality, includes treating it as a crosscutting theme in all sectors and adopting targeted measures to address egregious disparities. The ADB Gender Mainstreaming Guidelines established a four-tier system to gauge equality integration in projects: (i) gender equity theme, (ii) effective gender mainstreaming, (iii) some gender elements, and (iv) no gender elements. Following Strategy 2020, the ADB Results Framework established the gender mainstreaming corporate target whereby $45 \%$ of all projects to be processed until 2016 should meet the requirements for having a gender equity theme and effective gender mainstreaming. At the time of the conducting of this country gender assessment in 2015 , there were two projects processed in Tajikistan: (i) Strengthening Private Sector Participation in technical and vocational education and training (TVET); and (ii) Investment Climate Reforms Program-Subprogram 1, which were classified as having a gender equity theme and effective gender mainstreaming, respectively.

\section{A. Agriculture and Natural Resources}

Tajikistan is heavily dependent on agriculture, with this sector accounting for approximately $21 \%$ of gross domestic product (GDP) and employing close to half the labor force. ${ }^{276}$ The country, however, has limited arable land and a large portion is dedicated to cotton, which exacerbates food imports reliance (approximately 60\%). Around a third of the country's population is food insecure and $70 \%$ relies on farming, both directly and indirectly. ${ }^{277}$ Tajikistan is especially vulnerable to the adverse effects of climate change, but also has a very low capacity for adaptation. Agricultural production is especially vulnerable to changing weather conditions, natural disasters, and water shortages.

In its portfolio for 2015-2017, ADB has added agriculture and natural resources and anticipates projects on ensuring food security, improving water supply and irrigation

274 ADB. 1998. Gender and Development. Manila. p. viii.

275 ADB. 2008. Strategy 2020: The Long-Term Strategic Framework of the Asian Development Bank 2008-2020. Manila. 276 CIA World Factbook: Tajikistan. https://www.cia.gov/library/publications/the-world-factbook/geos/ti.html.

277 ADB. 2013. Tajikistan: 15 Years of Partnership with the Asian Development Bank, Development Effectiveness Brief. Manila. p. 15. 
efficiency, and building climate change resilience and mitigating natural disaster risks. ${ }^{278}$ Through a gender action plan (GAP) conducted as part of a project to increase Pyanj river basin climate resistance, ${ }^{279}$ ADB also ensures that women will benefit from flood protection activities and rehabilitated water supply infrastructure. It will provide basic information about women's role in agriculture, the impacts of poor water infrastructure, and climate change.

The Living Standards Improvement Strategy for 2013-2015 includes a section on ensuring food security through sustainable agriculture and effective use of land and water. While the same strategy outlines gender equality priorities, and includes an expected outcome on expanding rural women's access to land and entrepreneurship, there are no explicit objectives related to increasing women's role and status in agriculture or in decision-making around natural resource management. The Government of Tajikistan has supported gender-sensitive land restructuring and has also taken steps to mainstream gender into climate change policy. From 2003-2008, the government and the donor community jointly implemented two large projects, with UNIFEM taking the lead: Land Rights and Economic Security of Rural Women in Tajikistan, and Improved Food Security and Enhanced Livelihoods through Institutional and Gender Sensitive Land Reform in Tajikistan. These projects resulted, among other outcomes, in land legislation and policies becoming more gender sensitive, ${ }^{280}$ the establishment of a state coordination council and district task forces, the introduction of gender indicators and statistics, and greater outreach to and mobilization of dekhan farmers. ${ }^{281}$ In order to advance gender-sensitive climate change policy, the government reports that training and awareness-raising for Tajik women will be conducted jointly by the Women's Committee, the Committee on Emergency Situations and Civil Defense, and regional authorities. In addition, there were, "plans to include 1-2 women" from the Women's Committee in the official delegation to Conference of the Parties (to the Convention on Climate Change and the Kyoto Protocol) held in 2013.282

\section{Women's Role in Agricultural Activities}

Because Tajikistan has a large rural population, agricultural activities are a fact of life for many people. Rural households typically have small plots, or kitchen gardens, close to the house, and may also access other types of land plots: presidential land (which is further from the household and may not be irrigated), a parcel of land on a collective farm, or independent farmland (dekhan farms). Men and women may work on any of these land plots. While close to equal numbers of men and women are formally employed in agriculture, the share of women working in this sector is higher (of all working women, around $75 \%$ are estimated to be employed in agriculture). ${ }^{283}$ In fact, agriculture has increasingly become feminized in Tajikistan as a result of several factors. The collapse of the Soviet Union uprooted the collective farm system and left the rural population with fewer employment opportunities.

\footnotetext{
278 ADB. 2014. Country Operations Business Plan for Tajikistan 2015-2017. Manila. http://www.adb.org/documents/tajikistan-countryoperations-business-plan-2015-2017.

279 ADB. 2013. G0352 TAJ: Building Climate Resilience in the Pyanj River Basin. Manila.

280 Specifically, the Land Code and the Law on Dekhan Farms.

281 See, generally, V. Mirzoeva. 2009. Gender Issues in Land Reform in Tajikistan. Economics and Rural Development. 5 (2).

282 Submission of the Republic of Tajikistan under Decision 23/CP.18 Promoting gender balance and improving the participation of women in UNFCCC negotiations and in the representation of Parties in bodies established pursuant to the Convention or the Kyoto Protocol. 2013. http://unfccc.int/documentation/submissions_from_parties/items/5916.php

283 M. Abdulloev. 2013. Gender Aspects of Agriculture. Dushanbe: State Statistics Agency. p. 1.
} 
While men have migrated abroad to find better paying work, women have filled low-paying jobs in agriculture. Additionally, the global economic crisis of 2009 seems to have pushed more women into agricultural work due to increasing prices. ${ }^{284}$

It is very important to distinguish the different ways that women can be engaged in agricultural work, both in formal and other employment forms. According to a study conducted in Sughd viloyat, women are less likely to be employed under a formal contract than they are to work informally, part time, or seasonally. When former collective farm workers received land certificates, various new positions were created: collective owners (sahimdor, effectively an employee position with an obligation to work on the collective farm for a monthly cash salary); additional laborers (hectarchi, seasonal work with outputbased wages that are paid in cash or in-kind); and daily wage laborers (mardikor, short-term and flexible output-based work that can be on any farm. ${ }^{285}$ Of these three types of work, only sahimdor are entitled to benefits. Women also manage dekhan farms and work in household plots, both discussed in more detail below. It should also be noted that women in rural areas often undertake agricultural work as second and third occupations, typically on household plots and presidential lands (cotton farms). According to an assessment conducted in the Ferghana Valley (Sughd province), women were more likely than men to work on large collective farms as their primary occupation, but also that "many individual women's livelihood strategies included a mix of formal sector employment and small-scale commercial cultivation...female employment opportunities outside the home were limited to wage labor at the large farms (except for working on household plots and presidential lands)." 286 Men had greater opportunities for self-employment in non-farm businesses.

When land shares on collective farms were divided, there were no apparent gendered distribution differences. However, due to the large outmigration of men, today, the sahimdor workforce is primarily women. It is thought that "female family members take over the labor obligation of the migrated male family member to secure their work place and future pensions." 287 Even women who are working with a formal contract may take on additional and unregulated labor as hectarchi on collective farms. Such work is seasonal and paid in cash or in-kind. ${ }^{288}$ Work as mardikor has traditionally been considered inappropriate and even "shameful" for women because it is unpredictable and requires travel (even cross-border work in the Kyrgyz Republic), and often, "men do not much allow women to work or talk with unknown men (farmers) in order to negotiate their work price and to work far from their communities." ${ }^{89}$ Still, mardikor work is attractive to women because is short-term, flexible, and can pay better than other jobs. Interestingly, as more women have started to work as mardikor, they have begun to organize themselves into brigades led by one woman who can, "negotiate the workload and payment with individual dekhan farmers." ${ }^{290}$ The potential for such leaders to transition to formal sector work should be further assessed, but it has been noted that "some mardikor group leaders already had a list

284 Ibid. p. 2

285 See generally, N. Mukhamedova and K. Wegerich. 2014. Land Reforms and Feminization of Agricultural Labor in Sughd Province, Tajikistan. Colombo: International Water Management Institute (IWMI)

286 Agricultural Activities, Water, and Gender in Tajikistan's Rural Sector: A Social Assessment of Konibodom, Bobojon Ghafurov, and Yovon, p. 26.

287 Land Reforms and Feminization of Agricultural Labor in Sughd Province, Tajikistan, p. 16.

288 E. Kobzar. 2007. Gender Equality in the Agricultural Sector. Dushanbe: UNIFEM and CIDA. p. 17.

289 Land Reforms and Feminization of Agricultural Labor in Sughd Province, Tajikistan, p. 17.

290 lbid. 
of names of farmer clients who have been hiring them continuously; this might show signs of a small service business development."291

Despite women's prominent role in agricultural production, and, indeed, the feminization of the sector, there is little evidence that women have become empowered through it. In fact, gender experts point to the agricultural sector as one of the most exploitative. Gender imbalances in access to and control over productive resources, limited decision-making, and discrimination are also characteristic of agricultural work. A particular concern is the serious underrepresentation of women either as agricultural title owners or decision makers. Looking specifically at dekhan farms, the number managed by women has been rising alongside their general growth. In 2014, women headed 13\% of dekhan farms (up from $8 \%$ the previous year; see Figure 8 below). ${ }^{292}$ However, the average size of femaleheaded farms is smaller than those managed by men, and in 2014, women managed only $6.4 \%$ of all planted crop land on dekhan farms. ${ }^{293}$ Dekhan farms headed by females also have fewer shareholders (but more female shareholders) than farms headed by males. ${ }^{294}$ FGD participants for this assessment also noted that female-managed land is often poorer than that granted to men. This observation is reinforced by data that show how femalemanaged dekhan farms have significantly smaller harvests across all crop categories, and smaller yields for every crop save cotton and corn, which are nearly equal for men and women. ${ }^{295}$

Women have not benefited equally from land privatization, in terms of legal titles to land, because, "men have controlled the process." 296 Corruption, local clan affiliations, and local authorities' land distribution discrimination lead many land applications filed by households headed by females to be denied ("lack of manpower" was cited as a reason for denying applications from vulnerable households that lacked adult males). ${ }^{297}$ Customarily, family plots and presidential lands are registered to the household head, most often a male. Furthermore, documents that stipulate the right to use collective dekhan farm lands are generally not issued to all members, most of whom are women, but instead are issued in the name of the male head, most often the husband, brother, or, if a woman is widowed, her oldest son. Women reportedly, "do not know that once they leave the collective farm, [they] have a legal right to a land plot." 298 One study found that there is a widespread pattern of excluding women's names from collective and family farm certificates. Overall, in about $10 \%$ of cases, women's names were not included on certificates, but this figure varied by location (in Panjakent, for example, 70\% of collective dekhan farmers and over half of family farmers said that women were excluded). ${ }^{299}$ One of the reasons cited for not registering women was the monthly social tax assessed for each shareholder on the certificate (40\% of respondents cited this), but cultural norms and patrilineal ownership and inheritance patterns also place more importance on registering property in men's names.

\footnotetext{
291 lbid.

292 State Statistics Agency. Gender Statistics Database, http://www.stat.tj/en/Gender6/Genderbaz/ (accessed September 2015)

293 State Statistics Agency. 2015. Gender Indicators in Dekhan Farming. Dushanbe. p. 63.

294 Gender Equality in the Agricultural Sector, p. 21.

295 Gender Indicators in Dekhan Farming. pp. 77-94

296 Agricultural Activities, Water, and Gender in Tajikistan's Rural Sector: A Social Assessment of Konibodom, Bobojon Ghafurov, and Yovon, p. 4.

297 E. Gomart. 2003. Between Civil War and Land Reform. Among the Poorest of the Poor in Tajikistan. In N. Dudwick, E. Gomart, A. Marc and K. Kuehnast, eds. When Things Fall Apart: Qualitative Studies of Poverty in the Former Soviet Union. Washington, DC: International Bank for Reconstruction and Development/ World Bank. p. 89.

298 Gender Equality in the Agricultural Sector, p. 19.

299 International Bank for Reconstruction and Development and World Bank. 2012. Farmer and Farm Worker Perceptions of Land Reform and Sustainable Agriculture in Tajikistan. Washington, DC. p. 65.
} 
Women are often unaware that, as members of collective farms, they are granted equal rights, hence they do not pursue ownership claims. Additionally, women have fewer land restructuring information sources than men and report lower knowledge; more than 25\% of surveyed women said they had no sources of information on the topic. ${ }^{300}$ A survey of 1,800 farmers indicated that women were more likely to have no specialized training than men and specifically to lack vocational training (19.3\% of men as compared to $7.9 \%$ of women) and higher education (5.1\% of men and 2.2\% of women) in agriculture. ${ }^{301}$ Even among dekhan farm leaders, women's educational levels are considerably lower than men's, though women come to dekhan farming with prior experience (the majority as collective farmers and a smaller number of agricultural specialists). ${ }^{302}$

Agricultural work is a means of survival for many women, but it is also characterized by low pay, hard manual labor, and difficult working conditions. According to national statistics, the ratio of women's to men's wages in agriculture was 57.5\% in 2013 (compared to $86.8 \%$ in 2009). ${ }^{303}$ These figures refer only to registered work, while agriculture studies more generally reveal that low wages and irregular payment are common. Women who work on collective farms earn less than men (in one study, women earned TJS15-20 per monthmore during harvest season-as compared to men's earnings of TJS60 per month), or

Figure 8: Trend in the Proportion of Dekhan Farms Managed by Men and Women, 2006-2014 (\%)

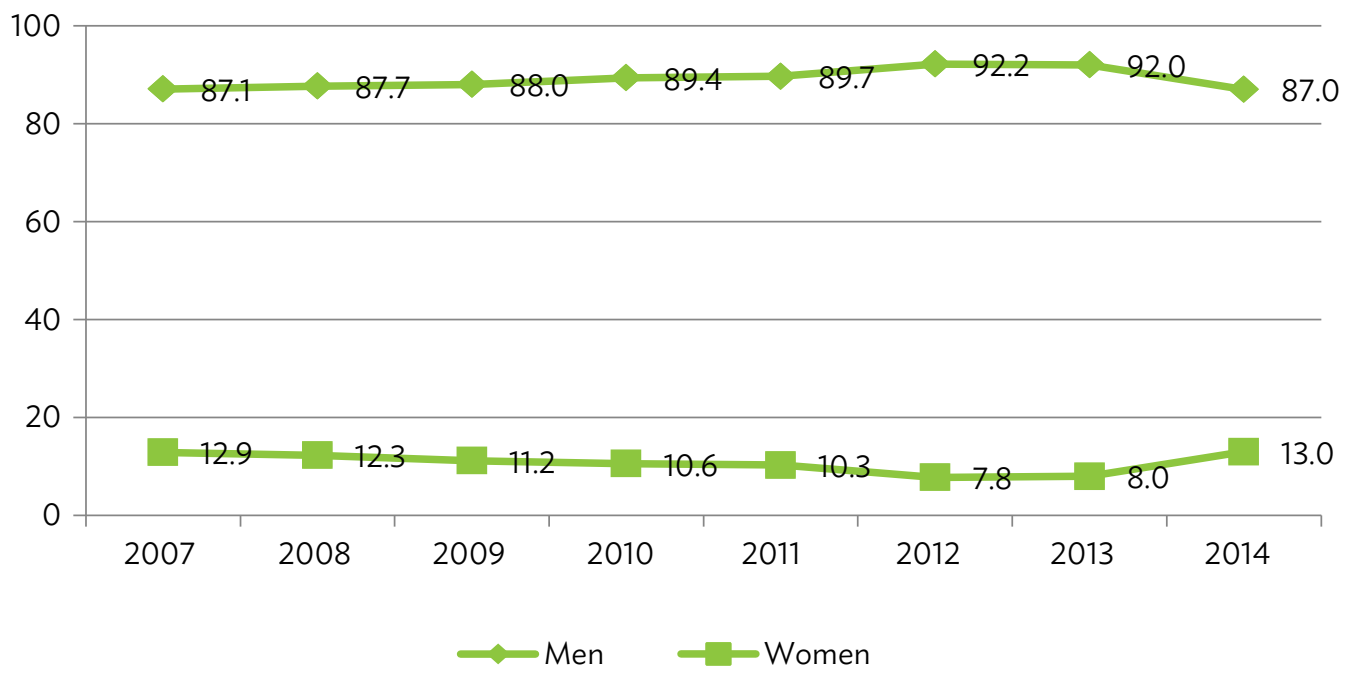

Sources: United Nations Office in Tajikistan. 2010. Millennium Development Goals, Tajikistan Progress Report. Dushanbe; and Government of Tajikistan, State Statistics Agency. Gender Statistics Database, http://www.stat.tj/en/ Gender6/Genderbaz/ (accessed September 2015). 
are paid in kind, partly due to men performing more specialized tasks. Research has also shown that women are often unaware of their rights to a salary. ${ }^{304}$ Due to obsolete and deteriorating farm machinery, "women perform most of the farm work by hand, and... women and girls must regularly carry heavy loads for several kilometers due to transport shortages." 305 During the growing season, women can spend 18 hours a day performing manual labor. ${ }^{306} \mathrm{~A}$ gender-oriented activity within a cotton-lending project offers an interesting case study of both the difficult conditions that women in agriculture face and the lack of gender sensitivity among male farm managers. In this project, the majority of farm managers were men, and they "did not feel the need for any social programs designed for women. Their focus was solely on farm productivity and performance." 307 By introducing the managers to better conditions for women through the lens of increased productivity and the respect for women that is part of Islam, almost of all of the farms implemented several of the recommended changes (e.g., providing gloves, clean and boiled drinking water, and field toilets).

\section{Gender and Water Resources}

For many women farmers, reliable access to water is a major concern. Despite Tajikistan's plentiful rivers and glaciers, the country's water infrastructure, both for irrigation and drinking, has deteriorated since the Soviet period, which has resulted in a paradoxical situation: "many areas face water shortages for irrigation and personal consumption, but many rural people and agriculture suffer the effects of rising water table and increasing soil salinity." ${ }^{308}$ Nationally, water distribution is "highly centralized" and organized around cotton farming; locally, however, "rural reforms and diminished direct public sector involvement have blurred responsibility for maintaining downstream irrigation systems, manifold-drainage networks, and household water delivery that used to be handled by state-owned enterprises." ${ }^{09}$ Considering the country as a whole, many rural households rely on unimproved water sources (28\%), and even those that have access to improved water sources rarely have piped water (see Table 7 below). Most households taking part in a survey in Sughd viloyat cited canals, streams, or rivers as their plots' primary water source, but they also use wells and springs for personal consumption; some also collected rainwater and very few reported paying for water. ${ }^{310}$

304 Gender Equality in the Agricultural Sector, p. 17.

305 Agricultural Activities, Water, and Gender in Tajikistan's Rural Sector: A Social Assessment of Konibodom, Bobojon Ghafurov, and Yovon. pp. 13-14.

306 OSCE Office in Tajikistan. 2010. Climate Change Survey in Tajikistan. Dushanbe. p. 21.

307 R. Billimoria, and A. Ergashev. 2010. Incorporating Gender Activities into Cotton Lending Project Design: High Impact at Reasonable Cost. Washington, DC: International Finance Corporation. p. 2.

308 Agricultural Activities, Water, and Gender in Tajikistan's Rural Sector: A Social Assessment of Konibodom, Bobojon Ghafurov, and Yovon, p. 15.

309 lbid. p. 17

310 Ibid. p. 19 
Table 6: Estimates of Household Drinking Water Sources

(\% distribution)

\begin{tabular}{|lcc|}
\hline & Urban & Rural \\
\hline Improved source & $\mathbf{9 4 . 6}$ & $\mathbf{7 0 . 7}$ \\
\hline Piped on premises & 78.2 & 22.1 \\
\hline Public tap/standpipe & 12.9 & 29.8 \\
\hline Well/borehole & 1.4 & 10.6 \\
\hline Protected dug well & 1.4 & 4.4 \\
\hline Protected spring & 0.4 & 3.6 \\
\hline & & \\
\hline Unimproved source & 3.7 & $\mathbf{2 8 . 2}$ \\
\hline Unprotected dug well & 0.2 & 0.6 \\
\hline Unprotected spring & 0.8 & 2.3 \\
\hline Tanker truck/cart & 0.8 & 6.1 \\
\hline Surface water & 1.9 & 19.2 \\
\hline
\end{tabular}

Source: Government of Tajikistan, State Statistics Agency, Ministry of Health and ICF International. 2013. Tajikistan Demographic and Health Survey 2012. Dushanbe, Tajikistan, and Calverton, Maryland. p. 14.

Women and girls typically collect water (both boys and girls start to collect water around age six, but boys do not continue once they have completed secondary school: "A woman can expect to continue carrying water into the house until she is no longer able to"). ${ }^{311}$ According to the 2012 Tajikistan Demographic and Health Survey (TjDHS), most rural households spend less than 30 minutes per round trip to collect drinking water, ${ }^{312}$ but it is common for women and girls to make four or five trips per day if carrying containers by hand and to travel several kilometers. In addition to collection, women shoulder the burden of storage and treatment, which is usually done by boiling, because they are the primary users of water for cooking, cleaning, washing clothes, bathing children, and making coal or dung briquettes for fuel; therefore, "they know how much water they need and so they organize for it to be collected accordingly." ${ }^{13}$ Women are said to know the value of household water while men are seen as more wasteful of it. These nonproductive uses of water are not considered in economic assessments, but when asked how improved water supply would affect their households women cite lessening their workloads, having more time for their children and leisure, improving household cleaning and family hygiene, and increasing their home-based agriculture capacity. ${ }^{314}$ Projects that improve safe water access could result in time savings for women and girls, but better baseline data are also needed to determine precisely how they have benefited in terms of more time for education, income-generating activities, or personal pursuits.

Women's role in organizing household water collection is not formalized in the community. Agricultural sector restructuring has necessitated a water management system, leading to the 2006 Law on Water Users Associations. Water users' associations (WUAs) regulate its

311 N. Tandon. 2011. Climate Change: Beyond Coping. Women smallholder farmers in Tajikistan. Oxford: Oxfam GB. p. 12.

312 Tajikistan Demographic and Health Survey 2012, p. 14.

313 Climate Change: Beyond Coping. Women smallholder farmers in Tajikistan, p. 12

314 Gender Assessment: SDC Rural Drinking Water Program in Tajikistan, p. 9. 
use, collect fees, and mitigate resource conflicts. Despite large numbers of rural men being absent because they are working abroad, women are generally not active in WUAs: "[M]ost rural women avoid active involvement in decision making, which hampers their inclusion in WUA structures. Women do not participate in community-based water management initiatives proportionate to their burden of livelihood maintenance, the rising trend of households headed by females, or their direct interest in improving water provision." 315 A study carried out in Sughd oblast found that the WUAs have not integrated all water users and that the associations, "serve mainly members consisting mostly of male owners/ directors of farms and representatives of jamoats." 316

Participants of FGDs for this assessment explained that another key position, the mirob (a local water master who controls irrigation) is always a man because the job requires physical strength. The Sughd study, however, documented several ways in which women have become more involved in local water management, albeit not in a formal or paid capacity. In some villages and dekhan farms, women have taken on the mirob role because men are largely absent and there is a demand for these skills. Also, the increasing number of households headed by females and "traditional and religious distancing of females from other non-kinsmen, [mean that] male water masters would not be able to enforce water distribution to kitchen gardens and collect fees from the [households headed by females]." 117 A male mirob would not be able to, "shout at women, fine them or close their water due to traditional manners," or because kitchen gardens are many households' main survival source. For similar reasons, WUAs have also increasingly involved women in gathering fees and giving them some oversight of household distribution (six women and two men spearheaded these tasks in the above-mentioned study). ${ }^{318}$ However, it appears that such women are not formally employed in WUAs or as mirobs, either full- or part-time (of the three reviewed WUAs, none had female employees). Still, this case study indicates that there is a recognized need for women to be engaged in local water management, and so the challenge is to formalize and expand their role.

\section{Climate Change and Gender}

The main indicators of climate change in Tajikistan are rising temperatures, uneven rainfall, and melting glaciers; these changes, in turn, can cause natural disasters such as flooding and mudslides or droughts. Rural populations are especially vulnerable to climate change given their dependence on small-scale farming and natural resources. Although rural people may not be familiar with the technical meaning of "climate change," they articulate two weather phenomena: seasonal variations and weather-related shocks. ${ }^{319}$ Indeed, women who participated in FGDs, particularly women farmers, described unseasonably warm weather followed by heavy rains that ruined crops.

As described above, rural women and female farmers typically have a triple work burden: employment for income, household and care responsibilities, and growing food for family consumption. Kitchen gardens are a vital source of income, especially for households

\footnotetext{
315 Agricultural Activities, Water, and Gender in Tajikistan's Rural Sector: A Social Assessment of Konibodom, Bobojon Ghafurov, and Yovon, p. xi. 316 Land Reforms and Feminization of Agricultural Labor in Sughd Province, Tajikistan, p. 14.

317 Ibid. p. 17.

318 Ibid. p. 20

319 Climate Change: Beyond Coping. Women smallholder farmers in Tajikistan, p. 9.
} 
headed by females, and a critical factor in household food security, since, for the average rural household, $54.9 \%$ of expenditures are on food. ${ }^{320}$ Households headed by females are among the poorest and "often have very limited capacity to cope with or recover from weather-related losses"; further, they will also be disproportionately impacted by staple goods scarcity. ${ }^{321}$ In addition to increased physical burdens associated with collecting scarce resources, women and children are at risk for illness from substandard drinking water and unclean fuel.

Women's lower educational levels, lack of technical knowledge, and limited participation in decision making also impact their climate change adaptability. The 2010 flooding in Kulyab, for instance, affected many women because they did not know how to react during an emergency and few could swim. ${ }^{322}$ Households headed by females that operate small farms exhibit fewer sustainable land management processes than households headed by males, which may be due to lack of technical knowledge or insufficient finances. ${ }^{323} \mathrm{As}$ previously noted, women are underrepresented in WUAs and are less likely to participate in household decisions about which crops to grow or how to invest income.

Despite agricultural sector gender inequalities, women have great potential as agents of change. Rural women are quick to "grasp the holistic nature of farming and offer examples and solutions that they are already engaging in to adapt to climate change." 324 Many of the focus group discussion (FGD) participants in this assessment had participated in renewable energy and environmentally safe practice projects and were interested in further work of this kind. A case study of a small project in a mountain community also demonstrated that simple technologies that women can implement can have a positive effect on food security. In this case, poor households received frames that enabled them to start herb and vegetable seedlings in cold weather and increase the growing season. Women also learned about food preservation. ${ }^{325}$ While the project was found to increase women's food security agency, it was not possible to determine whether it had a larger impact on unequal gender relations.

Household-level interventions targeting women are crucial in order to improve their awareness of climate change adaptability. But efforts are also needed at the local and national level to share best practices on "natural resource management, on adaptive and mitigative farming," and to increase information about women's rights with support through investment, credit, and technology. ${ }^{326}$ Women should also be engaged with policy, via both key leadership roles and civil society organizations (CSOs).

320 Women and Men of the Republic of Tajikistan, p. 11.

321 Climate Change: Beyond Coping. Women smallholder farmers in Tajikistan, p. 4

322 Climate Change Survey in Tajikistan, p. 21.

323 Autonomous Adaptation to Climate Change: Economic Opportunities and Institutional Constraints for Farming Households, p. 17

324 Climate Change: Beyond Coping. Women smallholder farmers in Tajikistan, p. 24.

325 Care International. 2010. Climate Change Brief: Adaptation, Gender and Women's Empowerment. p. 5.

326 Climate Change: Beyond Coping. Women smallholder farmers in Tajikistan, p. 26. 


\section{B. Education}

Access to education is one of the most critical issues for girls and young women today. Faced with the stark problem of girls' decreasing enrollment and completion rates, the government has prioritized gender parity in educational reform. For instance, the goals of the State Program for the Education, Selection and Placement of Capable Women and Girls in Leadership Positions for 2007-2016 include encouraging more girls to complete grades 10-11 and providing higher education scholarships for young women. The National Strategy for Enhancing the Role of Women in the Republic of Tajikistan for 2011-2020 also recognizes obstacles to education such as gender stereotypes and substandard school conditions. The National Strategy for Education Development of the Republic of Tajikistan 2006-2015 also includes a gender equality objective.

The most visible education gender disparity is the decline in the number of girls attending school, a trend that begins after they complete their primary education (around grade 6) and accelerates to the end of compulsory education (grade 9) ${ }^{327}$ In fact, girls' enrollment rates are lower than boys', beginning in preschool and continuing through higher education. While both boys and girls may be out of school for a variety of reasons, girls have higher rates of absenteeism and school drop-out. According to one estimate, approximately $50 \%$ of girls and $30 \%$ of boys have irregular school attendance. ${ }^{328}$ Another study found that only $40 \%$ of girls included in the sample attended school every day, and about $43 \%$ missed 3 or more days in a six-day week. ${ }^{329}$

Experts acknowledge that gender gaps are much larger than are officially indicated, and this is partly related to data not capturing the varied ways that girls and boys can be considered "out of school." Enrollment data do not track absenteeism or attendance. Estimating the total number of school-age children is also complicated by it being quite common for children's births not to be registered unless or until they are enrolled in school, especially in families with unregistered marriages (FGD participants also mentioned that children may be allowed to attend school with only a certificate: a "spravka"). ${ }^{330}$ A study conducted by the United Nations Children's Fund (UNICEF) and the Tajik Ministry of Education found that, among girls who were not attending school, some had been but were never registered locally, while others had attended for only a few years, and still others were not known to the system at all. ${ }^{331}$

\section{Pre-school Education}

The educational system in Tajikistan begins with noncompulsory pre-school, includes 11 years of compulsory secondary school, and encompasses vocational and higher professional education. ADB has supported secondary school reform through projects that included infrastructure rehabilitation, training for teachers, the establishment of parent-

327 United Nations Children's Fund (UNICEF). 2013. Global Initiative on Out-of-School Children: Tajikistan Country Study. Dushanbe. p. 31.

328 Ibid. p. 37.

329 S. Mirzoev. 2014. Joint Sector Review Report. Dushanbe: Ministry of Education and Science and UNICEF. p. 83.

330 Qualitative Survey on Issues in Girls'Education in Tajikistan: an in-Depth Analysis of the Reasons Girls Drop Out of School, p. 13.

331 Ibid. p. 26 
teacher associations, and piloting school attendance and retention schemes. ${ }^{332}$ From 2015, ADB has planned projects to strengthen technical and vocational education and training (TVET). Although the focus of ADB projects is on post-secondary and professional education, significant gender disparities begin during basic schooling and run through the entire educational system in Tajikistan, necessitating a comprehensive planning, implementation, and monitoring perspective.

The absence of preschool educational facilities (which can include nurseries, daycare centers, and kindergartens) was mentioned several times in FGDs, primarily as a factor that prevents women from working outside the home. Focus group participants from villages said that they had no pre-school centers, and those who lived closer to towns and cities explained that private kindergartens are too expensive for many households. In Garm, a participant who runs a pre-school described how it functions: attendance costs are TJS45 per month, but a reduced rate (subsidized by the local authorities) of TJS30 is available. These fees, however, only cover the basic costs, but not staff salaries or training, toys, or even costs to heat the building properly. While the focus groups discussed the possibility of opening private kindergartens as a form of small business, participants noted the burdensome regulations and licensing as a disincentive.

Children's access to pre-school is vital in terms of their own development and primary school preparedness. While the number of institutions and children attending pre-schools increased from 2012 to 2013, it is estimated that only 6.5\% of all children ages 1-6 are attending some sort of facility. ${ }^{333}$ An enrollment bias favoring boys is already observed at this level, but the main reasons that households give for not sending children to pre-school have no evident gender dimension: there are no available facilities (52\% of respondents) and they prefer to keep the children at home (27\%). ${ }^{34}$ Still, given that girls' absenteeism and dropping out of school at older ages stems from gender inequality, further study is warranted to understand why even when pre-school facilities are available, fewer girls are enrolled.

\section{Out-of-School Girls}

Total school enrollment has increased in Tajikistan, but gender disparities are acute after grade 9. Compared to the 2006-2007 academic year (when girls made up only $38.9 \%$ of students in grades 10-11), girls' enrollment in 2013-2014 showed improvement (around $45 \%$ of all students). ${ }^{335}$ Still, a disproportionate number of girls leave school across all regions, wealth quintiles, and in urban and rural areas. ${ }^{336}$ Table 7 shows the proportion of girls in grades 10 and 11 for the country as a whole and for the five provinces individually. There are clear differences in girls' enrollment by province, which can be partly explained by some regions relying more on agricultural work, which leads to absenteeism from school (e.g., Khatlon viloyat), and other regions having distinct cultural values (e.g., girls' education

332 These projects were completed by 2013. See ADB. 2013. Tajikistan: 15 Years of Partnership with the Asian Development Bank, Development Effectiveness Brief. Manila. p. 19. http://www.adb.org/publications/tajikistan-15-years-partnership-asian-developmentbank.

333 Women and Men of the Republic of Tajikistan, p. 65.

334 Global Initiative on Out-of-School Children: Tajikistan Country Study, p. 33.

335 Ministry of Education and Science of the Republic of Tajikistan. 2014. Statistical Collection of Education Sphere of the Republic of Tajikistan. p. 42

336 Global Initiative on Out-of-School Children: Tajikistan Country Study, p. 11. 
is "highly encouraged" in Gorno-Badakhshan Autonomous Province [GBAO]). Further examination shows that in specific rural DRS districts, girls' enrollment in grades 10-11 has been as low as $18.4 \%$ (Nurobadsky district), or did not reach 30\% (Rudaki and Tavildara districts) ${ }^{337}$ Especially concerning is the unexpected finding that girls in urban areas, particularly in and around Dushanbe, are out of school at higher rates than girls in rural areas. ${ }^{338}$ One reason could be that, in recent years, women's NGOs and local authorities have paid particular attention to the issue of girls' decreasing education.

Table 7: Proportion of Girls by Class and Province, 2013-2014 Academic Year (\%)

\begin{tabular}{lcc} 
Province & Proportion of Girls in Grade 10 & Proportion of Girls in Grade 11 \\
\hline Total Republic & 46.23 & 43.58 \\
Dushanbe & 40.78 & 37.92 \\
DRS & 39.20 & 35.67 \\
GBAO & 50.38 & 48.10 \\
\hline Khatlon viloyat & 47.47 & 43.78 \\
Sughd viloyat & 49.66 & 49.49 \\
\hline
\end{tabular}

DRS = Districts of Republican Subordination, GBAO = Gorno-Badakhshan Autonomous Province.

Source: Ministry of Education and Science of the Republic of Tajikistan. 2014. Statistical Collection of Education Sphere of the Republic of Tajikistan. Dushanbe. pp. 43-45.

Paradoxically, the declining number of girls completing their secondary schooling is accompanied by a widespread respect for girls' education in the abstract and "a wish to have more educated women in...communities." ${ }^{39}$ A USAID-sponsored survey of parents showed that a large majority agree with the statement that "girls and boys should have equal opportunities to go to school" ( $86.7 \%$ in a baseline assessment), but many also feel that "it is more important for boys to get an education than girls" (49.6\%). ${ }^{340}$

Many interrelated factors contribute to girls leaving school and also to their absenteeism. Research has shown, and FGDs under this assessment confirmed, that the most common reason given for girls' absence from school is poverty (usually characterized as lack of money for uniforms, textbooks, or other fees). Indeed, even though basic education is free in Tajikistan, there are many incidental expenses that can challenge impoverished families. The legacy of the Soviet system, in which education was guaranteed, has left the society unused to the idea of saving for children's education. ${ }^{341}$ (Noncollateralized credit is a major source of family funding for education). ${ }^{342}$ In-depth studies of out-of-school girls, however, demonstrate that the primary cause is not poverty alone, but poverty combined with deeply ingrained gender inequalities.

\footnotetext{
337 The Second Shadow Report on the Realization of the Convention on the Elimination of All Forms of Discrimination against Women by Public Organizations of Tajikistan, p. 34.

340 Note that the majority of the sample were female. R. Haarr. 2010. Safe Schools and the Reduction of School-Related Gender-Based Violence in Tajikistan: an Evaluation of Impact of Training on Teachers and Community Members. Dushanbe: Creative Associates International, Inc. p. 3.

341 S. Amjad. [no date]. Out-of-School Girls: Challenges and Policy Responses in Girls'Education in Tajikistan. UNICEF: Dushanbe. p. 160 342 Joint Sector Review Report, p. 23.
} 
Traditional and patriarchal societies expect girls to marry and join their husbands' families and boys to provide for their parents throughout their lives. Thus, the return on the household's investment in boys' education is seen as much greater than for girls, who are viewed as "temporary" members of their families. ${ }^{343}$ A study of families of girls who had dropped out of school found that the parents were quite passive regarding their daughters' education, allowing them to drop out for several reasons, but most families provided for their sons' education and hoped that they would attend university. ${ }^{344}$ FGD participants to this assessment noted that, in many families in which girls have dropped out, financial sacrifices are made for boys' education or money is found for nonessential purchases and for contributions to local mosques. Some households feel that it is better to save for the daughter's wedding than to invest in her education. Interestingly, FGD participants in Panjakent offered an alternative view of how households might allocate scarce resources: it is better to invest in girls' education because boys have more opportunities to work and can, "depend on themselves."

Gender roles also influence school leaving, and demand for unpaid and low-paid agricultural labor and household work results in more girls than boys withdrawing from school. Housework and caring for younger siblings or other family members is a frequently cited reason that girls drop out of school. Girls also work in agriculture, but as a general rule, not in paid labor. ${ }^{345}$ Eldest daughters are expected to take on household chores if their mothers are ill or are employed outside the home. It should be noted that boys' school attendance is also affected by household labor, but it seems to impact their enrollment to a lesser extent. It also appears that in abandoned migrant families, girls have the highest rates of dropping out after grade 9 (one study indicated that only $47 \%$ of girls in abandoned migrant families were enrolled in grades $10-11$, as compared to $89 \%$ of the boys). ${ }^{346}$

Early marriage for girls is both a cause and effect of school leaving. Once the learning process is disrupted, "women's early marriage in rural areas inevitably lower their likelihood of ever going back to school." 347 There is also evidence that families keep girls out of school in order to improve their marriage prospects. To "avoid speculation and maintain a solid reputation," some girls are kept at home with their mothers, and some families fear that school attendance itself will result in immoral behavior. ${ }^{348}$ When families view girls' primary prospect as marriage, the school curriculum subjects may seem ancillary. A large majority of parents stated that the advantages of school for their daughters extended to reading and writing and felt justified withdrawing them once they had attained these basic skills. ${ }^{349}$ Still, after they had dropped out, some girls were sent to local religious leaders for alternative education that purportedly provided skills more relevant to family life, including religious knowledge, sewing, and embroidery. ${ }^{350}$ The challenge is to convince families of the relevance of longer education to their daughters' futures in terms of attaining greater skills and knowledge, whether to prepare them for marriage or for their own self-fulfillment. Other social forces impact girls' school attendance, namely peer pressure to drop out

343 Out-of-School Girls: Challenges and Policy Responses in Girls'Education in Tajikistan, p. 160.

344 See generally, Qualitative Survey on Issues in Girls' Education in Tajikistan: an in-Depth Analysis of the Reasons Girls Drop Out of School. 345 Ibid. p. 30

346 The study notes that, due to a small sample size, the findings should be "treated with caution." UNICEF. 2011. Impact of Labour Migration on Children Left Behind in Tajikistan. Dushanbe: Oxford Policy Management. p. 63

347 Joint Sector Review Report, p. 27.

348 Global Initiative on Out-of-School Children: Tajikistan Country Study, p. 57.

349 Qualitative Survey on Issues in Girls' Education in Tajikistan: an in-Depth Analysis of the Reasons Girls Drop Out of School, p. 25.

350 Such instruction is provided by a female religious leader (bihatun) and is offered for free or for whatever cash or in-kind payment families can afford. Ibid. p. 32. 
and perceived inequalities that are greater for girls than boys. In case studies of girls who left school, many mentioned feelings of shame and tension at not being able to afford to dress like their peers as a cause, and all respondents (including school staff and parents) mentioned "the importance the community attached to the looks of adolescent girls." ${ }^{351}$

Poor infrastructure and school conditions lead to absenteeism for children in general, but have a particular impact on adolescent girls. Villages are often located considerable distances from schools, roads are insecure, especially in winter, and there is no public transportation. Not only do girls often lack suitable shoes and clothing for walking to school, but there are also concerns over their safety; culturally, "from the age of puberty girls are not supposed to walk alone." 352 Rather than walk to the next village to the school offering the higher level of education, girls will stop attending. In some regions, boarding schools have been created for children from remote areas, but even these are not necessarily accessible to girls. An FGD held in Garm showcased such a school, but, according to participants, all 26 students are boys because, "the conditions are not appropriate for girls." Girls' security at school may also be a concern for parents as GBV is more common when boys significantly outnumber girls in the classroom. ${ }^{353}$ Lack of piped water into schools, and inadequate sanitation (including lack of separate toilet facilities for boys and girls) also have a particular impact on adolescent girls due to their specific hygiene requirements. Many rural schools are inadequately heated, have frequent power outages, and do not have sufficient school furniture or materials. It has been suggested that the overall poor learning environment devalues the educational system in the eyes of parents and may serve as an additional disincentive if they are unsure about investing in their daughters' education. ${ }^{354}$ Interestingly, several programs suggest that even a relatively small incentive, such as providing free school meals and the opportunity to take a school meal home, can "stimulate the return of girls to schools" (66\% of girls were willing to continue their education past grade 4 if given a free lunch). ${ }^{355}$

Teachers play the greatest role in encouraging girls to stay in school, followed by their parents. ${ }^{356}$ Conversely, it is most often family members (particularly fathers) who discourage girls from attending school. Even in households where fathers are away in labor migration, it is reported that they will convey their decision that a girl should leave school to other family members, or the eldest brother will make such a decision. Male family members may be responsible for the immediate determination about a girl's schooling, but children's educational success is very closely tied to the mother's attainment. Not only do mothers with professional and higher education have the highest percentage of children in early childhood programs, as compared to women with lower educational attainment, ${ }^{357}$ but the daughters of these women are much more likely to attend secondary school. ${ }^{358}$ Critically, maternal education also correlates closely with the registration of children's births, children's nutrition and health, exploitation in child labor, and even household wealth. ${ }^{359}$

352 Global Initiative on Out-of-School Children: Tajikistan Country Study, p. 51.

353 Qualitative Survey on Issues in Girls' Education in Tajikistan: an in-Depth Analysis of the Reasons Girls Drop Out of School, p. 22.

354 Ibid. p. 25

355 F. Crestani. 2011. Torino Process 2010. Republic of Tajikistan. Turin: European Training Foundation. p. 13.

356 Global Initiative on Out-of-School Children: Tajikistan Country Study, p. 57.

357 Tajikistan Demographic and Health Survey 2012, p. 32

358 Torino Process 2010. Republic of Tajikistan, p. 12-13.

359 See, generally, State Statistics Agency. 2007. Tajikistan Multiple Indicator Cluster Survey 2005, Final Report. Dushanbe. 
Several NGOs described successes in projects addressing the problem of out-of-school girls through joint community work with parents, religious leaders, local authorities, and school administrators. One NGO described how some families of girls who left school early, married, and were subsequently divorced became convinced of the importance of education when they saw the lack of employment options for women who only have basic education. Such families encourage their daughters to take special courses, even driving groups of young women to NGO centers for training. Projects working with families on an individual basis are effective, but also time-consuming and intensive. Approaches that emphasize the importance of female education, not only to women's futures, but also in terms of the well-being of their children, are also needed.

\section{Professional and Higher Education}

The gender inequalities that exist in secondary education are magnified in both technical and vocational education and training and in higher education. Considering all of tertiary education combined, there is a "clear bias in favor of males," the converse pattern to what is observed in other Central Asian countries. ${ }^{360}$ Poverty and isolation from urban centers are also barriers to higher education. The 2007 Tajikistan Living Standards Survey (of 4,860 households) illustrated gender differences in academic attainment between women and men. In 2011, for every 100 men enrolled in higher education, there were only 41 women. ${ }^{361}$

Table 8: Selected Education Levels of Adult Men and Women (\%)

\begin{tabular}{lcccc} 
& No education & $\begin{array}{c}\text { Complete } \\
\text { secondary }\end{array}$ & $\begin{array}{c}\text { Professional } \\
\text { or technical }\end{array}$ & University \\
\hline Percentage of men aged 15 and over & 0.5 & 45.9 & 15.7 & 13.2 \\
Percentage of women aged 15 and over & 0.9 & 51.4 & 6.7 & 4.8 \\
\hline
\end{tabular}

Source: European Training Foundation. 2011. HCD Review. Relationship Between Human Capital Development and Equity in the Republic of Tajikistan. Turin. p. 11.

In addition to the gender imbalance in higher education overall, specific enrollment patterns can also be observed in the various post-secondary educational institutions. Figure 9 below illustrates the differing proportions of male and female students enrolled in tertiary education during the 2013-2014 academic year.

While the overall enrollment rate in vocational education has declined, of particular concern is that the proportion of enrolled women has steadily decreased from $28.1 \%$ of all students in 2005 to the current rate of $18.0 \%{ }^{362}$ If they continue past compulsory education, women are more likely to pursue secondary vocational education, but this choice may reflect the very narrow subjects that they choose to study.

360 World Bank. 2013. Republic of Tajikistan Gender Diagnostics Note. Washington, DC. p. 23 
Figure 9: Distribution of Student Enrollment by Type of Educational Institution, 2013-2014 Academic Year

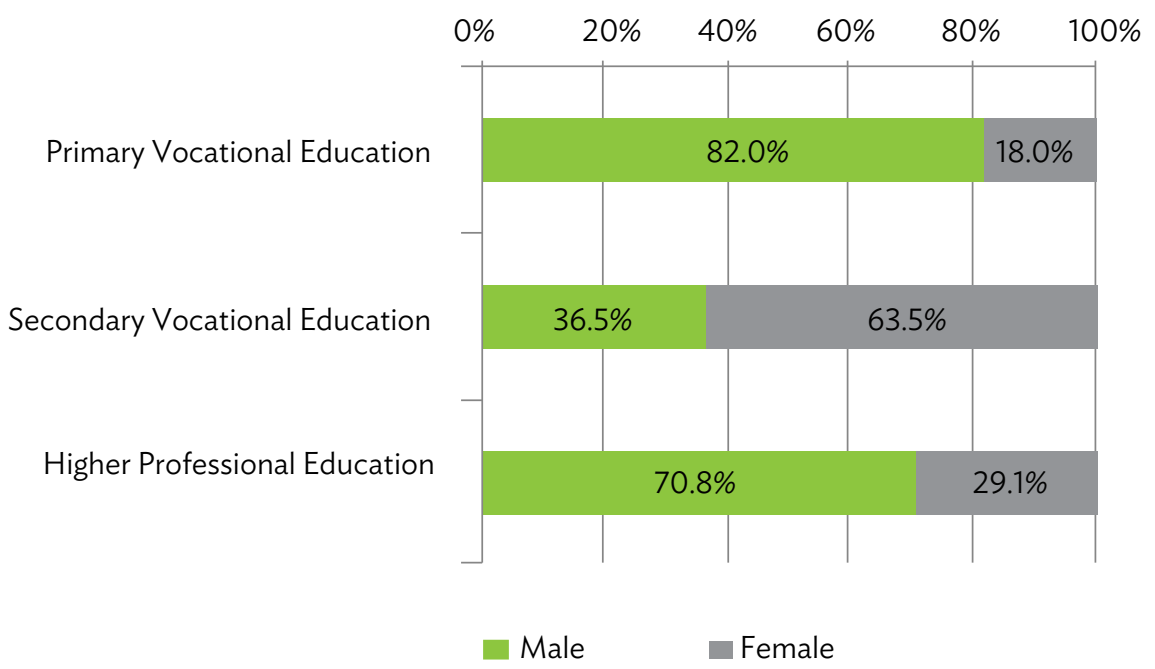

Source: Government of Tajikistan, State Statistics Agency. 2014. Women and Men of the Republic of Tajikistan. Dushanbe. pp. $73,76,80$.

\section{Box 6: Technical and Vocational Education and Training in Tajikistan}

The term "technical and vocational education and training" is not used in education laws in Tajikistan. Instead, the post-secondary educational system consists of: primary vocational education (taught in "PTUs"); secondary vocational education (colleges); higher professional education (institutes and universities); and adult education (short-term courses and training centers). Primary and secondary vocational education is under the Ministry of Education, and the system of adult education is the responsibility of the Ministry of Labor, Migration, and Employment. Concepts of lifelong education or adult education are not well developed. Under the Tajik system, PTUs are isolated from the general education system (graduates are expected to enter the job market and very few continue in higher education), and these institutions are largely, "dead-end educational pathways for those who are studying there."

a Abbreviation from the Russian professional-technical school.

b F. Crestani. 2011. Torino Process 2010. Republic of Tajikistan. Turin: European Training Foundation. pp. 23-24.

In the 2013-2014 academic year, $89.1 \%$ of all female students in secondary vocational education studied either health or education (62.2\% and $26.9 \%$, respectively). ${ }^{363}$ In technical subjects, such as economics and management, construction, transport, agriculture, energy, metallurgy, and mechanical engineering, men made up virtually $100 \%$ of the student population. As shown in Figure 10 below, men and women also enter distinct higher education fields. Such clear gender segregation patterns in academic subjects 
suggest that there has been little to no attention paid to identifying and removing the barriers to women's entering technical areas of study in vocational institutions. In theory, women's professional training in health care and education could address a demand that exists for such services, but a lack of government investment that would stimulate workplace growth in these sectors means that the "workload is thus growing whereas wages remain low in these two female dominated fields." 364 Despite the large number of women working in agriculture, few train as specialists in this field. Furthermore, the absence of women in technical fields of study means that investment in infrastructure will not directly benefit women in terms of employment opportunities.

\section{Figure 10: Distribution of Male and Female Students in Higher Education by Academic Subject, 2013-2014 Academic Year}

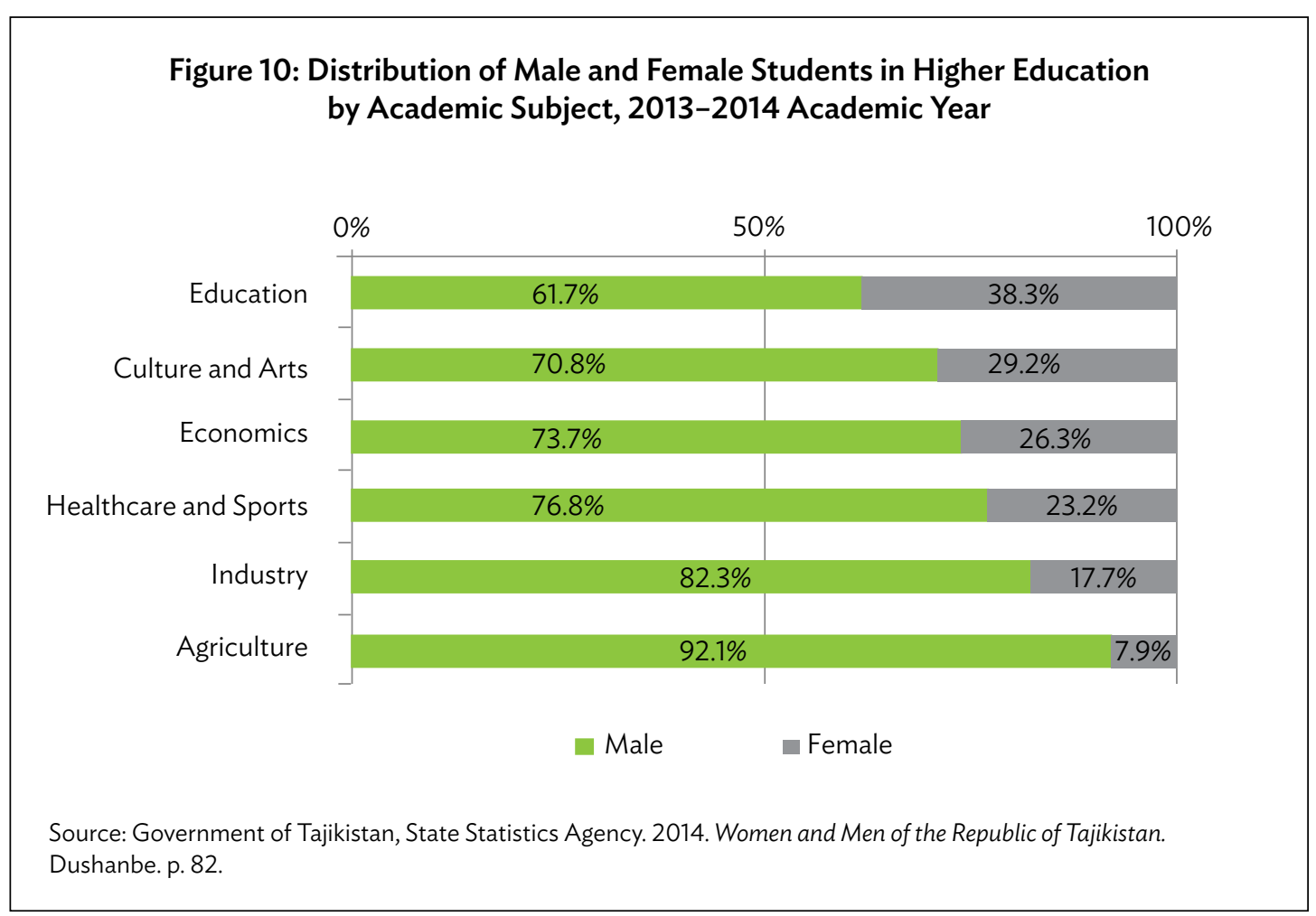

In terms of academic specialization, the Survey on Initial Education indicates that just under half of men (43.2\%) and women (44.4\%) agree that their field of study was chosen with migration in mind. ${ }^{365}$ Young women are generally pursuing subjects that will not lead to in-demand jobs, but the TVET system as a whole is not very responsive to current job market demands, neither in Tajikistan, nor even in the Russian Federation. FDG participants point out the need for short vocational training courses that are aimed at potential migrants, both male and female.

364 Torino Process 2010. Republic of Tajikistan, p. 11.

365 European Training Foundation. 2011. HCD Review. Relationship Between Human Capital Development and Equity in the Republic of Tajikistan. Turin. p. 20 


\section{Efforts to Improve Girls' Access to Higher Education}

Since the late 1990s, the government has taken special measures to encourage girls from remote areas to enroll in higher education. Most significantly, the Presidential quota system has been renewed three times (2001-2005; 2006-2010; and 2011-2015).The first Presidential quotas pertained only to girls from remote regions, but after 2006, the program included boys. Annually, the number of quota-derived higher education students has increased (from 970 in 2007 to 1,220 in 2013), with girls making up slightly more than half the recipients. ${ }^{366}$ The quota system allows students to enter university with simplified entrance exams. According to Ministry of Education data from 2008, the number of female students who entered higher education under the quota fell short of projected numbers. ${ }^{367}$ Furthermore, while the quota system is an acknowledged good practice, concern has been raised over its lack of comprehensive support.

The gender inequalities that cause girls to drop out of school after grade 9 also pressure young women to abandon higher education. The amount of Presidential quota financial assistance is very small and can "hardly cover expenses necessary to continue studies in higher education institutions." 368 Many families are unable to finance higher education or, for the reasons described above, they prioritize girls' marriage rather than their continued education. Young women face increasing pressure to marry, and studying away from home jeopardizes safety and reputations. In some districts, girls who study at university and graduate when they are 22 or 23 years old are no longer considered "good candidates for marriage." ${ }^{369}$ Mothers are said to prefer that their sons marry uneducated girls, fearing that a daughter-in-law "with a university education, who is financially independent, might decide to challenge the family system." ${ }^{770}$ If young women marry while still in higher education, their husbands or in-laws may prohibit their studies. Participants in FGDs commented that PTUs, colleges, institutes, and universities are located in urban centers and few have dormitories or other residency options that would be considered appropriate for young women. Given the inadequacies of many primary and secondary schools, young women from rural areas who are admitted under the quota system are often not well prepared for higher education and drop out. ${ }^{371}$

The Presidential quota is partly administered by local hukumats, which are responsible for managing the application process. This arrangement can leave the process open to "new interpretations locally regarding what gender quota reform entails and how gender quotas should be administered. For example, female students received quotas for studying less popular and usually lower-paid professions traditionally perceived as 'feminine' (such as nurses and teachers), while few quotas were given to women for studying more popular, higher-paid professions (such as law, economic, business and international relations)."372 Data about female and male quota beneficiaries' study subjects could not be found for this assessment. However, FGD participants said that even when young women complete

366 Statistical Collection of Education Sphere of the Republic of Tajikistan, p. 287.

367 I. Silova. and T. Abdushukurova. 2009. Global Norms and Local Politics: Uses and Abuses of Education Gender Quotas in Tajikistan. Globalisation, Societies and Education. 7 (3). p. 367.

368 lbid. p. 370.

369 Global Initiative on Out-of-School Children: Tajikistan Country Study, p. 58.

370 Ibid. p. 56

371 Global Norms and Local Politics: Uses and Abuses of Education Gender Quotas in Tajikistan. p. 371.

372 lbid. p. 372. 
their higher education, they rarely return to their home towns or villages due to lack of job opportunities in their specialty. ${ }^{373}$

\section{Girls with Disabilities and Access to Education}

The Tajik educational system's accessibility to children and adults with disabilities warrants special attention and should be the subject of specific research. Here, it is important to consider the situation of girls with disabilities in the larger context of gender disparities in education. The lack of sex-disaggregated data about children with disabilities greatly complicates understanding their educational system status. Data from 2013 indicated that girls made up only $39 \%$ of children with disabilities who were attending special classes. ${ }^{374}$ In general, children with disabilities face stigmas, and many people believe that they should not attend mainstream schools; this attitude is especially prevalent in rural areas $(78.5 \%$ of rural respondents to a survey expressed this view). ${ }^{375}$

The head of a disabled persons organization (DPO) for women and girls interviewed for this assessment explained that girls with disabilities have very limited opportunities for education. Families often prefer to keep girls at home, either to educate them there or out of concern for their safety. Girls with disabilities are generally not expected to work or marry, in contrast to boys with disabilities, so families are unlikely to prioritize their education. As a result, women with disabilities have lower literacy rates and higher unemployment rates than men with disabilities. ${ }^{376}$

When children with disabilities are offered education and training, they are generally slotted into courses based on gender stereotypes: sewing for girls, and shoemaking for boys, for example. The DPO mentioned above is working to empower women and girls with disabilities to make their own decisions about the kind of training and employment they would like and also to give them the self-confidence to voice these views.

\section{Energy}

Tajikistan has greater hydroelectric power capacity than any other Central Asian country ( $4 \%$ of the world's total), but these resources have not been exploited fully. The government prioritizes foreign investment to restore Soviet-era power stations and is also committed to developing alternative energy sources. Solar power, for example, has considerable potential, but it is currently little used. Infrastructural shortcomings mean that the country does not produce enough energy during the winter, but there is also no capacity to export the surplus energy that is produced in summer. The country has been dependent on electricity and gas imports from Uzbekistan and Turkmenistan.

373 The Second Shadow Report on the Realization of the Convention on the Elimination of All Forms of Discrimination against Women by Public Organizations of Tajikistan, p. 20

374 Statistical Collection of Education Sphere of the Republic of Tajikistan, p. 56

375 Torino Process 2010. Republic of Tajikistan, p. 14.

376 Bureau on Human Rights and Rule of Law, Disabled Women's League Istirok and UN Women. 2012. Respect for the Rights of People with Disabilities in Sughd Province. Second Phase Monitoring Report. Khujand. p. 55. [in Russian] 
In 2007-2008, Tajikistan experienced a particularly severe winter, a time when water supply is naturally low, that resulted in a humanitarian crisis. Soon after, the country was cut off from Uzbek natural gas supplies. Since then, Tajikistan has relied almost completely on domestic hydropower plants for its power, resulting in severe load-shedding in winter (when demand for electricity is highest) and power restrictions for most of the population. With the exception of Dushanbe and GBAO, most households receive electricity for only three to seven hours per day during the winter. ${ }^{377}$ The large rural population is especially vulnerable to the impacts of high energy costs. Despite $98.8 \%$ of rural households having electricity, ${ }^{378}$ they nonetheless rely heavily on solid and fossil fuels, or use other coping mechanisms, such as only heating only two rooms in the house, one for males and one for females. According to the 2012 TjDHS, around three in 10 households burn solid fuels for cooking, most of them in rural areas. Since 2005, the number of households across the country reporting solid fuel use for cooking has decreased (from $48 \%$ to $41 \%$ in rural households, and from $8 \%$ to $3 \%$ in urban households). ${ }^{379}$

Table 9: Cooking Fuel Used by Urban and Rural Households

(\% distribution)

\begin{tabular}{|c|c|c|c|}
\hline \multirow{7}{*}{ 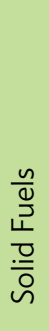 } & Cooking Fuel & Urban & Rura \\
\hline & Electricity & 75.1 & 42.3 \\
\hline & Liquid petroleum gas/natural gas/biogas & 21.3 & 16.8 \\
\hline & Wood & 2.6 & 29.2 \\
\hline & Straw/shrubs/grass & 0.1 & 1.2 \\
\hline & Agricultural crop & 0.1 & 2.8 \\
\hline & Animal dung & 0.6 & 7.4 \\
\hline
\end{tabular}

Source: Government of Tajikistan, State Statistics Agency, Ministry of Health and ICF International. 2013. Tajikistan Demographic and Health Survey 2012. Dushanbe, Tajikistan, and Calverton, Maryland. p. 13.

A survey limited to Sughd and Kahtlon oblasts and Dushanbe found a high prevalence of solid fuel use for cooking: $60 \%$ of respondents used solid fuel, $23 \%$ used electricity, and $19 \%$ used propane. ${ }^{380}$ Households in these locations are also more likely to use fuel-burning stoves for heating than electric heaters. In the above survey, $83 \%$ of households reported using open fire furnaces or stoves for heating, 15\% used electrical appliances, and less than $2 \%$ made use of either gas stoves (or traditional "sandal" stoves), or electric battery heaters. ${ }^{381}$ Heating household water also requires solid fuel. The majority of households (54\%) use firewood or coal to heat water for domestic purposes, followed by water heaters (branded and homemade water heaters combined: $39 \%$ ). Other methods, including solar water heaters, are used by few households. The $1.2 \%$ of respondents using domestic solar equipment indicates that there is a growing interest in alternative energy sources; as more technologies become available locally, uptake might improve. ${ }^{382}$

\footnotetext{
377 World Bank. 2014. Assessment of Household Energy Deprivation in Tajikistan. Policy Options for Socially Responsible Reform in the Energy Sector. Washington, DC. p. vi.

378 Tajikistan Demographic and Health Survey 2012, p. 13.

379 lbid.

380 Habitat for Humanity Tajikistan. 2014. Needs Assessment/Baseline Survey Report (for ADB Access to Green Finance Project) Dushanbe. p. 10

381 lbid. p. 11.

382 lbid.
} 
ADB energy projects have focused on modernizing and expanding electricity generation, transmission, and distribution, with institutional and technological reform to improve sector efficiency and regional cooperation for the energy trade. Further, through its Access to Green Finance project, poor households are eligible for microfinance geared to increasing domestic energy efficiency. A GAP pays special attention to women borrowers. This section of the assessment focuses on the gender issues implicated in the energy sector as a whole, and information about women's access to credit is discussed in the section on entrepreneurship development.

\section{Baseline Data and Gender-Sensitive Indicators}

It is expected that the population as a whole will benefit from improved energy supply and greater reliance on clean energy sources. The specific benefits are not articulated in national or regional development plans, and no energy project gender assessments could be found. There is a general lack of sex-disaggregated energy sector data that could establish a baseline. For example, time use surveys (the most recent from 2007) have limited information about women's domestic activities in energy-poor households. The economic value of women's unpaid labor in gathering or processing solid fuels has also not been calculated. Sector assessments tend to focus on technical insufficiencies and measure quantifiable energy outputs, and overlook gender-specific project impacts, especially in terms of renewable energy. Qualitative indicators should be developed to measure the extent that improved access to clean energy benefits women and girls.

\section{Women and Energy Poverty}

Energy poverty affects women and men differently in terms of roles and access to resources. Domestic energy expenditures are high, with rural households spending on average $10 \%$ of total income on energy (and up to 15\% in winter). For urban areas, excluding Dushanbe, households spend on average $6.5 \%$ of total income on energy and $11 \%$ during winter. ${ }^{383}$ The burden is especially heavy on the poorest rural households, which spend $24 \%$ of total income on energy during the heating season. ${ }^{384}$ Remittances are a key coping mechanism for high energy expenses. Most labor migrants leave in early summer and return to Tajikistan in late fall or winter, so "remittances are often brought or sent in the summer or early fall specifically for the purchase of winter fuels." ${ }^{385}$ It could not be determined how abandoned wives of migrants cope with high energy costs. However, there is virtually no difference in the average monthly electricity consumption in households headed by males and households headed by females (some of which could be considered abandoned), ${ }^{386}$ which suggests that women do not restrict energy consumption and so most likely spend a larger proportion of their income on energy.

Households that can afford it purchase gas for cooking and coal for heating, but there is heavy reliance on supplementary fuels that cannot be stored away. Male household heads are responsible for buying firewood, and women and children are responsible for collecting

383 Assessment of Household Energy Deprivation in Tajikistan. Policy Options for Socially Responsible Reform in the Energy Sector, p. 29. 
it. ${ }^{387}$ Households with livestock press and dry dung to use as fuel, a labor-intensive task for females, as well as coal powder briquettes. Many families rely completely on animal dung as a fuel source, and annual consumption has been estimated at 20 tons per household. ${ }^{388}$ Cotton stalks are also a source of fuel; some households collect them from their own fields, or women working as day laborers in cotton fields receive them as in-kind payment. ${ }^{389}$ The task of gathering, preparing, and storing alternative fuels is generally time consuming and arduous. ${ }^{390}$ Interviewees from ecological organizations pointed out that in many areas women now spend more time collecting wood because of deforestation. In the case of some villages in the Pamir region, women and children have to travel 15 or more kilometers for fuel (where they once travelled 2-4 kilometers), sometimes spending the night in the field. NGO research shows that an average household burns 400-500 bundles of firewood a year that, if purchased, would cost around 50 diram each in rural areas. ${ }^{391}$ So women's unpaid labor collecting firewood, or other fuels, effectively brings the equivalent of TJS250.

Daily tasks are hindered when energy resources are insufficient, and women who participated in FGDs described how they are acutely aware of the power outage schedule and must hurry to finish domestic chores when they have electricity to do so. Participants also reported that they have many standard labor-saving electrical appliances in their homes, but because of electrical outages, they cannot always use them. The TjDHS indicates that rural households are less likely than urban households to have those appliances that would be of particular benefit to women, presumably due to insufficient energy supply (see Table 10 below). The time that women spend gathering fuel, as well as performing household work without the aid of modern equipment, means that they have less time for productive and personal activities or rest.

Table 10: Selected Household Goods Owned by Urban and Rural Households (\%)

\begin{tabular}{lrc}
\hline Goods & Urban & Rural \\
\hline TV & 97.9 & 95.8 \\
\hline DVD player & 86.4 & 77.8 \\
\hline Computer & 25.0 & 6.9 \\
Refrigerator & 77.3 & 35.0 \\
\hline Freezer & 6.1 & 2.1 \\
\hline Electric fan & 54.0 & 39.8 \\
\hline Washing machine & 39.6 & 10.9 \\
Vacuum cleaner & 48.1 & 13.1 \\
\hline Sewing machine & 49.7 & 63.3 \\
Indoor heater/stove (burzhuika) & 36.4 & 87.0 \\
\hline Mini-generator (dvizhok) & 8.8 & 16.4 \\
\hline Wood/fuel stock & 36.9 & 93.3 \\
\hline
\end{tabular}

Source: Government of Tajikistan, State Statistics Agency, Ministry of Health and ICF International. 2013. Tajikistan Demographic and Health Survey 2012. Dushanbe, Tajikistan, and Calverton, Maryland. p. 19.

387 Assessment of Household Energy Deprivation in Tajikistan. Policy Options for Socially Responsible Reform in the Energy Sector, p. 8. 388 Climate Change: Beyond Coping. Women smallholder farmers in Tajikistan, p. 17.

389 See generally, Land Reforms and Feminization of Agricultural Labor in Sughd Province, Tajikistan.

390 Women and Men of the Republic of Tajikistan, p. 152. [English version]; and Women and Men of the Republic of Tajikistan, p. 90. [Russian version]. 391 Note that costs were accurate in 2007 and may have increased since then. Gender Equality in the Agricultural Sector, p. 18. 
Focus group participants in Nau reported that several households have mini-generators or electricity storage systems that migrant family members have brought from the Russian Federation, and which cost TJS3,000-TJS5,000.

Women and children spend more time in the home than men and are burdened by insufficient heating. Rural households being reliant on solid fuel for cooking and water heating also impacts women's health as they are more likely to be exposed to air pollution. Children and the elderly are also susceptible to respiratory health problems due to burning solid fuels, and female family members usually bear the responsibility of caring for relatives when they are ill.

\section{Impact of Energy Insufficiencies on Small Business}

According to a World Bank survey, Tajik firms experience around six power outages a month, with small firms (1-19 employees) experiencing the highest number, 6.6. With firms of all sizes, the power outages result in a $4.5 \%$ loss in sales. ${ }^{392}$ Energy shortages undoubtedly compromise many businesses, but the impact is especially serious for the smallest businesses, including home-based and microenterprises where many women are employed. In fact, participants in a study of Tajikistan energy deprivation noted that "the highest consumption expenditures for electricity are faced by urban and rural household entrepreneurs who run their small businesses out of their homes. These include, for example, business activities such as tailoring, or food preparation, such as baking bread, which require large amounts of energy." ${ }^{393}$ Respondents to the present assessment confirmed that "typical" business ventures for women involve sewing, handicrafts, and food production; female entrepreneurs who own small sewing workshops explained that they struggle to fulfill orders during electricity shortages. Women farmers in a KurganTyube FGD explained that due to lack of refrigeration, their milk spoils in warm weather before they have a chance to sell or process it. Notably, these entrepreneurs employed local women and wanted to expand production, offer training courses for more women, and take on additional staff, but their capacities are limited by several factors, including energy poverty. Women with livestock businesses complain of their difficulties entering new markets and making export deals due to a lack of computers and internet access, and prolonged power cuts during autumn and winter. ${ }^{394}$ Women operating small businesses may not have the capital to invest in generators or even to pay high electricity tariffs. It is important that female entrepreneurship schemes consider possible ways to assist women running micro- and small businesses to transition to more affordable or sustainable energy sources.

\section{Access to Information and Resources on New Energy Technologies}

Transitioning to renewable sources of energy and energy-efficient equipment has great potential to alleviate household burdens, but, given Tajikistan gender dynamics, men and women have differing levels of relevant information access. A survey suggests that male household members are more aware of energy prices and consumption, most likely "because they are primarily responsible for earning money, purchasing fuels, and arranging

392 International Finance Corporation. 2013. Enterprise Surveys: Tajikistan Country Profile. Washington, DC: World Bank. p. 14. http://www. enterprisesurveys.org/

393 World Bank. 2014. Assessment of Household Energy Deprivation in Tajikistan. Policy Options for Socially Responsible Reform in the Energy Sector. Washington, DC. p. 23.

394 GIZ. 2015. Pasture Management Networking Platform. Informational Newsletter. April-June 2015. Dushanbe. p. 5. 
delivery." ${ }^{395}$ Because female household members are responsible for preparing alternative fuels, they tend to be less aware of purchase price, but most likely have different strategies for energy affordability. Nevertheless, interviewees from ecological organizations with community-based energy efficiency projects report that women are interested in learning about alternative sources and have been engaged in small-scale demonstration projects.

Knowledge about home energy efficiency is not widespread, but women are less likely than men to report having heard about energy efficiency. ${ }^{396}$ Men also have a more varied understanding of energy efficiency. However, a survey revealed that women have similar knowledge to men about specific elements of energy-efficient house design, which is surprising in a culture where construction is considered purely a "male job." 397 Women are more aware than men of household electrical appliances' energy-saving features, which is expected given their domestic responsibilities. ${ }^{398}$ Women's knowledge of energyefficient construction is attributed to their greater involvement in building management in families of labor migrants. While the husband or other male family members are sending remittances home, and they, "manage remotely any major activities at home...inevitably their wives play a significant role in implementation of planned activities." 399

Women's knowledge of and interest in energy efficiency is a good foundation on which to expand their involvement in decision making. Women are prevented from being more engaged in this field by cultural barriers and traditions that portray major household decisions as more appropriate for men. An ecological organization expert who took part in this assessment described work experience in GBAO. When the organization offered practical training on renewable energy technology, no women attended the meetings, yet they had very specific perspectives on solar water heaters and the design of cook stoves that differed from the issues that men prioritized. Solar cookers are affordable (about TJS775), but women may still not be in a position to decide about using household funds for purchasing them. Women's lower educational status also serves as a barrier to their understanding family finances and being able to access credit to invest in energy-efficient home improvements. At present, there are no government programs with incentives for adopting new energy technologies, but several organizations have microfinance schemes for this purpose.

\section{Women's Energy Sector Representation and Decision-making}

At the household level, women's interest in new technology and basic awareness of efficiency suggests that they could play a key role in implementing energy interventions, including home improvement, if their capacity is improved and they are empowered as decision makers. ${ }^{400}$ Experts also point out that some people are reluctant to adopt solar power because they do not know how to maintain or repair the equipment, and once renewable energy becomes more common, specialists with technical skills will be needed. Technical and vocational education and training in renewable energy could be developed with special attention to attracting female students. Women make up the minority of

395 Assessment of Household Energy Deprivation in Tajikistan. Policy Options for Socially Responsible Reform in the Energy Sector, p. 18. 396 Needs Assessment/Baseline Survey Report (for ADB Access to Green Finance Project, p. 12.

397 Ibid. p. 8.

398 lbid.

399 Ibid. p. 16

400 lbid. 
students in technical fields. There were 32 female students studying "power engineering" in secondary vocational institutes during $2013-2014,{ }^{401}$ and the small figure suggests that special measures would be needed to assist women to enter this field. Energy companies may also have a role to play as providers of efficient services, and both technical fields and customer service could offer employment to women. Data were not available for the representation of women in energy companies, but the average number of men employed in electricity, gas, and water supply is more than five times higher than the average number of women. ${ }^{402}$ Though males dominate formal decision-making about renewable energy, an interviewee from an ecological NGO explained that there are examples of increased women's community and national representation as department heads and in deputy positions, but not at the jamoat or district level, where many decisions are made about adopting new technologies in schools and clinics, for instance.

\section{Entrepreneurship and Enterprise Development}

The private sector has been expanding in Tajikistan, although it accounts for a smaller share of the economy than in neighboring Central Asian countries at only $50 \%-55 \%$ of GDP. Developing the private sector and attracting investment are cornerstone national living standards strategies for poverty reduction, with a focus on improving the business climate through legislative reform, streamlining regulation, especially the process of starting a business, and building entrepreneurs' capacity. In recent years, the government has undertaken steps to support entrepreneurship that have been primarily, "aimed at creation of the state-level legal, social, economic, financial and institutional conditions necessary for the formation of a strong private sector economy...." 403 The introduction of "one window" business registration has greatly simplified the process of opening a business. Although business laws and regulations do not include any gender-specific provisions, support for women's entrepreneurship has been a component of larger reforms since 2006. The National Strategy for Enhancing the Role of Women in the Republic of Tajikistan for 2011-2020, for example, includes a strategic goal of supporting women's businesses via increasing women's competitiveness on the labor market generally. Particular attention should be paid to developing more equitably run family-and home-based businesses, women's employment in agriculture, and retraining for unemployed women.

ADB's private sector development projects for 2015-2017 include support for further investment climate reform, increasing public-private partnerships, and strengthening the finance sector by introducing new services. ${ }^{404} \mathrm{ADB}$ also encourages the development of women's small and medium-sized enterprises (SMEs) through training and grant programs.

Under Tajik law, small, medium-, and large-sized businesses are defined according to their annual turnover. There is no distinction for microenterprises, but individual entrepreneurs fall within the category of small business. There is no legal definition of a "women's business."

401 Women and Men of the Republic of Tajikistan, p. 79

402 lbid. p. 90.

403 T. Bozrikova. 2011. Business Environment Assessment of Female Entrepreneurship in Tajikistan. Geneva: UNECE. p.19. 404 Country Operations Business Plan for Tajikistan 2015-2017. 
Table 11: Turnover Rates of Enterprises

\begin{tabular}{lll}
\multicolumn{1}{c}{\begin{tabular}{c}
\multicolumn{1}{c}{ Small } \\
enterprises
\end{tabular}} & \multicolumn{1}{c}{$\begin{array}{c}\text { Medium-sized } \\
\text { enterprises }\end{array}$} & \multicolumn{1}{c}{$\begin{array}{c}\text { Large } \\
\text { Enterprises }\end{array}$} \\
\hline $\begin{array}{l}\text { Individual entrepreneurs/sole } \\
\text { proprietors }\end{array}$ & & \\
\hline $\begin{array}{l}\text { Legal entities }{ }^{*} \text { with annual turn- } \\
\text { over up to TJS500,000 }\end{array}$ & $\begin{array}{l}\text { Legal entities with annual turnover } \\
\text { from TJS500,000-15,000,000 }\end{array}$ & $\begin{array}{l}\text { Legal entities with annual turnover } \\
\text { of more than TJS15,000,000 }\end{array}$ \\
\hline
\end{tabular}

Notes: ${ }^{*}$ Enterprises undertaking several specific activities (i.e., banking, insurance, investment, delivery of aluminum) are excluded.

Source: Article 5, Law on State Protection and Support of Entrepreneurship in the Republic of Tajikistan (2014).

Individual entrepreneurs must obtain either a patent (a license) or a certificate from the tax authorities in order to operate. Patents provide for simpler taxation, but the holder cannot engage in import or export, exceed a threshold annual turnover, or hire employees, and is limited to the activities and geographical area listed therein. A certificate is more flexible in terms of types of business activities and employees, but holders are subject to stricter accounting under one of two possible tax regimes.

\section{Defining a "Women's Business" in Tajikistan}

Gender analysis in SME development is complicated by incomplete data about women and men working in business, either as owners or employees. Not all official data, such as number and types of registered businesses, are sex-disaggregated. Available figures can be inconsistent and give only a partial view of women's role in private enterprise due to varying definitions and methodologies. The terms "women's business" and "female entrepreneurship" may refer to different activities depending on the context. For instance, the National Association of Business Women of Tajikistan (NABWT) organizes a nationwide competition for female entrepreneurs and women's business initiatives, with the requirement that contestants must, "direct/manage the business or organization that they represent." 405 In contrast, a government grant scheme for women requires applicants to be the registered business owners, and an ADB grant program is available to specific groups of women who have plans for start-ups with the requirement that they register their business if they are selected for funding. In practice, the term "women's business" can, therefore, refer to enterprises owned by women, managed by women, or, in theory, with a majority of female employees.

\section{Baseline Data and Gender-Sensitive Indicators}

Examining women's representation among registered owners of individual enterprises, a general positive trend can be seen in their activity as both patent and certificate holders. In 2014, women represented $21.3 \%$ of individual entrepreneurs operating on the basis of a patent and $38.0 \%$ operating on the basis of a certificate. ${ }^{406}$ Note that while the actual

405 See Competition Rules for Farah 2012. NABWT website: http://nabwt.tj

406State Statistics Agency. Gender Statistics Database, available from http://www.stat.tj/ru/gender/generbazeng/ (accessed September 2015). 
number of female entrepreneurs increased annually from 2010-2014, the number of male individual entrepreneurs declined considerably from 2012-2013, which resulted in a larger proportion of women. After the "one window" system was introduced in 2009, the total number of individual entrepreneurs registering with tax authorities increased and in 2011, women represented $14.7 \%$ of sole proprietors overall. ${ }^{407}$

Paradoxically, it appears that women's participation in firm ownership is greater than in management. According to World Bank survey data, 9.7\% of all firms in Tajikistan have female top managers, with the majority concentrated in the smallest enterprises (women constituted $11.7 \%$ of top managers in small firms [1-19 employees]; 8.2\% of top managers in medium firms [20-99 employees]; and 4.1\% in large firms [100 or more employees]). ${ }^{408}$ The female management rate is significantly lower than that for the Eastern Europe and Central Asian region combined (21.1\%). The absolute number of women managers (not necessarily top management) in private sector entities increased steadily from 550 in 2008 to 1,862 in $2014,{ }^{409}$ but given that the total number of firms also increased, it is not known whether the proportion of women in management increased, decreased, or remained static. World Bank data indicate that many firms have some female participation in ownership (32.7\% of all firms combined, or $25.1 \%$ of small firms, $41.5 \%$ of medium-sized firms, and $36.7 \%$ of large firms). ${ }^{410}$ Given women's considerably lower representation in management, it is likely that women who are listed are owners and are nominally included, usually in family-owned enterprises, but are not undertaking day-to-day operations.

In terms of private sector employment, in 2014, small businesses (those with 10 or fewer employees) employed around 30,200 people, of which $21 \%$ were women. ${ }^{411}$ Between 2008-2014, the total number of people employed in small enterprises increased by more than 10,000, but the representation of female workers has remained close to $20 \%$ throughout this period. ${ }^{412}$ The only exceptions were observed in 2009, when the number of small business-employed women dropped to 14\% and then again in 2010 when the number of women increased to almost a third of all employees (32.6\%). It is likely that these variances are connected to labor migration patterns affecting Central Asia and the Russian Federation (e.g., after the 2008 economic downturn, the Russian Federation reduced migrant labor quotas; at the same time, the Tajik government encouraged the private sector to create jobs locally). It appears that returning male migrants found work in small enterprises in Tajikistan before again leaving for work abroad when conditions improved.

There is no official information about how many registered businesses are functioning or the number of people who are de facto engaging in entrepreneurial activity without patents or certificates. A respondent to this assessment noted that there have been several projects in Tajikistan to help women develop income-generating activities, but that they do not necessarily lead to their formally registering a business. National private sector development strategies that address women's entrepreneurship include only general goals, not specific targets. In order to develop women's entrepreneurship growth indicators,

407 Business Environment Assessment of Female Entrepreneurship in Tajikistan, p. 20.

408 Enterprise Surveys: Tajikistan Country Profile, p. 13.

409 Gender Statistics Database, available from http://www.stat.tj/ru/gender/generbazeng/ (accessed September 2015).

410 Enterprise Surveys: Tajikistan Country Profile, p. 13.

411 Gender Statistics Database, available from http://www.stat.tj/ru/gender/generbazeng/ (accessed September 2015).

412 lbid. 
some comprehensive information is needed about activities, women's role in managing and employment in enterprises, sectors, longevity and success of businesses, etc.

\section{Characteristics of Women's Businesses}

Women's businesses tend to be smaller and are often at the individual level. Female entrepreneurs face difficulties acquiring raw materials and equipment, as well as production areas and business premises, all of which mean that women's entrepreneurship "is focused on such industries and activities that do not require large start capital and can do without large investments, skipping, if possible, real productive activity." 413 Women's businesses are concentrated in sectors where large number of workers are not required, meaning nonproduction and service-oriented area, or they work in high-risk areas, such as shuttle and market-based trade. Women's businesses are in fields that are traditionally considered female specializations. There are no official data about the sectors in which women and men register businesses, but an examination of female entrepreneurs who have applied for and received grants through national competitions gives some indication of where women are most active. Through a program administered by the Women's Committee, 120 female entrepreneurs have received grants for projects in the following areas: establishment of sewing workshops and revival of local handicrafts (30\%), culinary businesses (15\%), honey production (20\%), production of produce (15\%), cattle breeding (15\%), and services (5\%). ${ }^{414}$ The 125 participants of the 2014 National Women Entrepreneurs of the Year competition ("Farah") represented the following sectors: services, such as domestic services, beauty salons, wedding salons, dry cleaners, hotels (39\%), agriculture (17\%), handicrafts and fashion design (13\%), medicine and education (12\%), and production/manufacture (10\%). ${ }^{415}$ Note that the Farah competition nominated women's businesses in the specific categories listed above, as well as general categories for start-ups and innovation. Among the finalists for the 2014 Farah competition were entrepreneurs representing nontraditional sectors such as construction, transportation, and industrial production. A survey of entrepreneurs also demonstrated that while enterprises run by women employ fewer workers, they tend to hire more women (on average, women's enterprises employed four women and two men, while men's businesses employed six men and four women). ${ }^{416}$ Because they are smaller and concentrated in specific sectors, women's businesses, "exhibit a much lower performance level in annual turnover or in annual profits relative to men's enterprises." ${ }^{\prime 17}$ Not only will it be important to expand opportunities for women to enter more lucrative, nontraditional sectors, but support is also needed to expand women's enterprises as a way to increase female employment.

413 Business Environment Assessment of Female Entrepreneurship in Tajikistan, p. 45

414 Statement of Mahfirat Khidirzoda, Head of the Committee on Women and Family Affairs of Tajikistan. Farah-2014 Journal. National Association of Business women of Tajikistan (NABWT): Khujand. p. 79.

415 Statement of Gulbahor Makhkamova, NABWT General Director. Farah-2014 Journal. p. 5

416 Business Environment Assessment of Female Entrepreneurship in Tajikistan, p. 25.

417 S. Sattar. 2012. Opportunities for Men and Women: Emerging Europe and Central Asia. Washington, DC: World Bank. p. 74. 


\section{Gender and Obstacles to Starting and Running a Business}

Male and female entrepreneurs face many common problems in terms of starting and running businesses, such as access to finance, unfavorable tax rates, poor infrastructure, political instability, and corruption. However, prevailing gender norms are also responsible for women's lower representation in business. Despite the increasing number of women engaged in entrepreneurship, it is still a male-dominated activity, and women face discrimination and stereotyping. As noted, the basic business laws in Tajikistan are gender neutral: they do not discriminate against women, but neither do they incorporate measures that would offset the barriers that women face in order to achieve equal outcomes for women and men. ${ }^{418}$ When asked whether state policy to improve the business environment has had a positive effect on entrepreneurship, women and men vouchsafed few disagreements, but respondents representing legal entities and farmers were much more likely to rate state policy as favorable, as compared to individual entrepreneurs. ${ }^{419}$ Given that the number of women taking patents is smaller than the number taking certificates, it would be useful to explore how business regulation is specifically impacting both female and male sole proprietors.

Taxation and regulation are cited as difficulties for all entrepreneurs, especially for startups. In a survey, an approximately equal number of business-focused women and men maintained that the current taxation levels are unacceptable, with this sentiment being echoed in FGDs held for the present assessment. More female entrepreneurs than male, however, specified that the variety of taxes and rates are onerous and that the current taxation regimen undermines business. ${ }^{420}$ Further information is needed about gendered impacts of taxation on entrepreneurs in different sectors and with businesses of varying sizes. Women also reported experiencing discrimination, and in some cases sexual harassment, on the part of tax authorities when they were registering businesses and making payments. ${ }^{421}$ Women face greater bureaucracy when registering a business; reportedly women who own incorporated businesses need an average of 10 days more than men to register their companies. ${ }^{422}$ Government and regulatory agencies being staffed mainly by men is also an obstacle, particularly for conservative women, who would find it difficult to interact with such institutions. In addition to regulatory burdens, female entrepreneurs in rural areas highlight infrastructure problems, specifically poor sanitary conditions and lack of alternative energy sources that can be used in autumn and winter, as major business impediments. ${ }^{423}$ As noted in the preceding section on energy, small homebased business that are typical of female entrepreneurship are energy intensive and have the highest electricity expenditures.

Female entrepreneurs are disadvantaged by their unequal access to human and social assets, such as business networks, specialized knowledge and skills, and even businessrelated information. For example, according to one survey, women entrepreneurs are more likely to have fixed suppliers, while men entrepreneurs more often deal with a variety of

418 Business Environment Assessment of Female Entrepreneurship in Tajikistan, p. 46.

419 Ibid. p. 26.

420 Ibid. p. 36

421 lbid. p. 37.

422 Opportunities for Men and Women: Emerging Europe and Central Asia, p. 73.

423 M. Bobokhanova. 2011. The Path to Developing Women's Entrepreneurship in Rural Areas of Tajikistan. (Presentation, UNECE Policy Seminar on Women's Entrepreneurship Development in Central Asia, Geneva, 19 September 2011). 
vendors, which gives greater price options. ${ }^{424}$ Business associations and service-oriented NGOs are a vital resource for entrepreneurs, especially at the start-up stage. Of note, surveyed female entrepreneurs were slightly less familiar with such business-supporting agencies in Tajikistan, but they were more likely to know about organizations that assisted women in business (one in four women was aware of such organizations as compared to one in eight men). ${ }^{425}$ Most of the same surveyed female entrepreneurs were unaware of the Presidential entrepreneurship grant program or concessional microfinance for women. These findings have important implications for the further development of business associations and NGOs that are accessible to women, and the need to increase outreach to female entrepreneurs as well as generally to raise the profile of such organizations generally.

Women's general lower level of education also impacts their abilities to run their businesses. Many women have limited informal education or even experience making independent decisions about finances, which means that they also lack essential knowledge and confidence to make business decisions. According to one survey, $70 \%$ of women reported not knowing the monthly income of their household. ${ }^{426}$ While this phenomenon can be partly explained by remittance income fluctuations, it is also a cultural norm for male heads of households to deal with finances. Women have less exposure to such decisions, which leads them to be unprepared for business decision-making and overly averse to initiating entrepreneurial activity or using credit.

Female FGD participants for this assessment also drew attention to the need for knowledge about marketing and how to expand their businesses, especially concerning legislation, taxation, regulations, and social fund payments. Rural women, in particular, are constrained by their limited agricultural technological knowledge, and lack of training relevant to areas where they could start businesses. ${ }^{427}$ Women entrepreneurs' access to information is limited by their having lower internet usage and less access to e-mail and broadband services than male entrepreneurs. ${ }^{428}$

Positive characteristics of female entrepreneurs include that they are responsible, especially in terms of repaying loans, and are, "willing to use advice from more experienced colleagues... and place greater importance on interpersonal relationships," 429 meaning they are quite flexible, innovative, and willing to explore new and niche markets.

\section{Access to Commercial Loans and Microfinance}

All Tajikistan entrepreneurs face high interest rates and credit access issues. Despite loan requirements being gender neutral, in reality, women have more limited access to credit due to lack of collateral, lack of business experience, high interest rates, and personal aversion to taking on risk. Data from the Association of Microfinance Organizations of Tajikistan for 2015 show that, on average, women received $26.7 \%$ of all microfinance

424 Business Environment Assessment of Female Entrepreneurship in Tajikistan, p. 38.

425 lbid. p. 30

426 A. Pandya. and K. Wilkinson. 2011. A Seat at the Table: The Role of Microfinance in Women's Economic Empowerment in Tajikistan. pp. 31-32.

427 The Path to Developing Women's Entrepreneurship in Rural Areas of Tajikistan 
loans. ${ }^{430}$ In comparison, National Bank of Tajikistan records indicate that women accounted for $32.3 \%$ of microloan recipients in $2014^{431}$ (presumably, an aggregate of borrowers from microfinance institutions and banks). More significant than the number of borrowers, the amount of credit that women receive is less than what men receive. In 2013, women were $37 \%$ of microfinance borrowers, but only accounted for $28.9 \%$ of the total amount of loans. Similarly, $30 \%$ of loans from commercial banks were issued to women, but only $26.1 \%$ of total loan amounts. ${ }^{432}$

It should be noted that both women and men take loans for various purposes, not only for business; in 2015, $16 \%$ of issued credit was in consumer loans. ${ }^{433}$ Although men are more likely to apply for business loans, female entrepreneurs themselves frequently have to borrow money to launch or run a business (54.2\% of women had borrowed money for this purpose in one survey), ${ }^{434}$ with rural women particularly lacking start-up capital. Women less frequently apply for loans through commercial banks due to several factors, but lack of collateral is the reason most frequently cited. As previously described, women rarely independently own property, such as real estate or livestock, that can be used as a pledge, and also lack the autonomy to make decisions about how such property could be used. Women who participated in FGDs for this assessment explained that for loans of up to $\$ 5,000$, no collateral is needed, and for more than $\$ 5,000$ but less than $\$ 10,000$, household property, such as a television, refrigerator, or carpet, could be used. Loans of $\$ 10,000$ or more would require a car or house as collateral. While women might be able to use jewelry to secure small loans, it generally has too low a value for business loans.

Interest rates are also a deterrent to women who are concerned about their ability to make repayments. When asked what rates would be acceptable, female FGD respondents were divided between two groups: those who are at the start-up level (including agriculturalbased businesses), and those who already have SMEs. According to the first group, even $2 \%-2.5 \%$ interest is too high for a one-year term loan. Women who have agricultural businesses, in particular, cannot predict crop yields and this makes them uncertain about whether they will be able to cover repayments. Women who run larger and more established businesses stated that they would be able to repay loans at an interest rate of $15 \%$ annually (they also noted that current interest rates in commercial banks are around 33\%). Suggestions from FGD participants to improve women's access to business credit included schemes to provide loans that are interest-free for the first year or to create venture capital funds.

Aside from the procedural aspects of applying for loans, female entrepreneurs face difficulties in applying for credit. Women are more likely to borrow money from relatives or friends, or to rely on remittances, than to use financial institutions for business loans; still, they use even these sources less than men. There are strong beliefs that "women simply should not take a credit, that they should take care of the family, and that they should not

430 Association of Microfinance Organizations of Tajikistan (AMFOT). 2015. Financial-Economic Review of Tajikistan for the Second Quarter of 2015. Dushanbe. p. 27.

431 Gender Statistics Database, available from http://www.stat.tj/ru/gender/generbazeng/ (accessed September 2015).

432 AMFOT. AMFOT Members Statistical Data Analysis for the Reporting Period of 01 January to 31 December 2013. pp. 6-7.

433 Financial-Economic Review of Tajikistan for the Second Quarter of 2015, p. 30.

434 Business Environment Assessment of Female Entrepreneurship in Tajikistan, p. 34. 
be in contact with strangers, particularly men." ${ }^{\prime 35}$ Approximately $13 \%$ of surveyed women entrepreneurs reported that they experienced discrimination when applying for a loan. ${ }^{436}$

Microfinance has been an important resource for female entrepreneurs in Tajikistan, and legal reform as well as consolidation has led to better coverage. Microfinance is particularly attractive to women because of the less stringent collateral requirements and because group loans are possible, an option that women prefer. Group guarantees, the recommendation of local authorities (the jamoat), and guarantees of close relatives can serve as collateral for microfinance, ${ }^{437}$ and when women take group loans, one representative can interact with the lending organization so that others do not have to leave the home. ${ }^{438}$ Microfinance is useful for women who are engaged in microenterprises, small-scale production, or providing limited services, and allows women to contribute to the household income and employ family members.

Finally, it should be kept in mind that data about the number of women who receive loans are not a measure of whether they are also empowered to make decisions about how the funds are used. One possible explanation for the relatively high number of women who received microfinance in 2008 was that men were aware of programs focusing on female borrowers and so they took, "advantage of the system by sending their wives or daughters to take out business loans that will actually be used by the male family members." 439 Gender norms can also influence women who take loans independently, and they may not necessarily also be empowered to make financial decisions. A study tracking women who took part in business training and later received loans found that, in general, men are more likely to make decisions about the use of loans ( $94 \%$ of male respondents as compared to $88 \%$ of female respondents). ${ }^{440}$ When women were asked specifically about household decisions on financial services, in $21 \%$ of cases the husband controlled the loan; in $44 \%$ of cases, decision-making was equal; and in $35 \%$ of cases, women controlled the loan. ${ }^{441}$

\section{Effects of Gender Stereotypes}

How society perceives female entrepreneurs, and indeed how they perceive their own capacities, has a considerable impact on women's success in business. In an FGD held with women entrepreneurs for this assessment, all agreed that the stereotype of business being atypical for women exists in Tajikistan. In the above-mentioned survey, every third respondent felt that both the business world and the general public, "think differently about female and male entrepreneurs," and one in four women answered that society does not equally support male and female businesses. ${ }^{442}$

435 Tajikistan Gender Diagnostics Note. Report No: ACS5015, p. 49

436 Business Environment Assessment of Female Entrepreneurship in Tajikistan, p. 45

437 Ibid. p. 35.

438 Tajikistan Gender Diagnostics Note. Report No: ACS5015, p. 50.

439 A Seat at the Table: The Role of Microfinance in Women's Economic Empowerment in Tajikistan, p. 38.

440R. Gravesteijn. 2012. Microfinance and Women Entrepreneurship: An Impact Assessment of a Start-up Loan Programme, IMON

International, Tajikistan. Dushanbe: ILO. p. 6.

441 Ibid. p. 20

442 Business Environment Assessment of Female Entrepreneurship in Tajikistan, p. 45 
Women are also influenced by societal perceptions and can lack confidence in their own abilities to start and run a business. In an FGD with established female entrepreneurs (all finalists in the 2014 Farah competition) conducted for this assessment, many noted the importance of receiving public recognition for their work and placed great value on the intangible forms of support they received from their peers. Likewise, most of the FGD participants reported that family support was crucial to their successes. Female entrepreneurs attach greater value to such support than males because cultural expectations would make it more difficult for them to operate without the express approval and support of their family (almost a third of female entrepreneurs-29.6\% - said that family support was critical, in comparison to $18.8 \%$ of males). ${ }^{443}$ The influence of family members is also a primary reason why women do not start businesses (cited by $24 \%$ of surveyed women who had received entrepreneurship training). ${ }^{444}$ Related to gender stereotypes, women's childcare and domestic roles mean that the time they can devote to entrepreneurial activities is much more limited than it is for men. More than half of surveyed female entrepreneurs cited the lack of childcare and institutions for the elderly as impediments to business (of note, two-thirds of the female respondents had three or more children). ${ }^{445}$ Seven percent of women who had received business training cited pregnancy as a reason for not starting a business. ${ }^{446}$

\section{Support for and Promotion of Women's Entrepreneurship}

There are many initiatives in Tajikistan to empower women economically, with most focusing on increasing women's entrepreneurial activities through business training and, in some cases, small grants. FGD participants for this assessment were familiar with such projects and pointed out that in order to support women's start-ups, basic training is a necessary first step, including comprehensive business plan assistance. Training must be followed by grants or special credit lines. Without finance provisions, participants maintained that "women will not be able to take the next step, and their training will go to waste." A study of combining training with microfinance found a strong positive correlation between self-employment and business expansion among women who had received both entrepreneurship training and loans, as well as a small negative impact for those who received training alone. ${ }^{447}$ Also notable, while the program positively impacted business registration, it had no measurable effects on women reinvesting income into the business or on women's empowerment more generally. Such findings suggest that women's entrepreneurship programs could be reevaluated in terms of their effectiveness and also regarding whether they are based on realistic assumptions that training and credit opportunities are sufficient for women to launch and grow their businesses. When asked their opinion of special programs, almost half of female entrepreneurs (45\%) held the opinion that such support does not improve the overall business environment. Their recommendations included more specialized and practical training on how to run a business, concessional loans and loan guarantees for women, business incubators for women, and small business support centers. ${ }^{448}$

443 lbid. p. 46.

444Microfinance and Women Entrepreneurship: An Impact Assessment of a Start-up Loan Programme, IMON International, Tajikistan, p. 30.

445 Business Environment Assessment of Female Entrepreneurship in Tajikistan, p. 45.

446 Microfinance and Women Entrepreneurship: An Impact Assessment of a Start-up Loan Programme, IMON International, Tajikistan, p. 30. 447 Ibid. p. 26.

448 Business Environment Assessment of Female Entrepreneurship in Tajikistan, p. 27. 


\section{Box 7: Grants for Women Entrepreneurs}

In 2006, the President of Tajikistan established a grant program to develop women's entrepreneurship, funded through the state budget, administered by the Women's Committee, and allocated by an inter-governmental committee. Grants are awarded annually to female entrepreneurs and NGOs. Both the number of grants and the amounts involved have increased since the program's inception. For 2011-2015, 80 grants were established: 20 grants each for TJS10,000, TJS20,000, TJS30,000, and TJS40,000. ${ }^{a}$ From 2006-2013, a total of TJS6,300,000 was allocated in grants under this program to 210 women entrepreneurs, 96 NGOs, and four individuals, and 23,000 women became employed. ${ }^{b}$

The NABWT founded the Farah award for women entrepreneurs, held through a competition in 2012 and 2014. The competition serves to raise awareness of women's entrepreneurship and also provides winners with grants and business-related prizes. In 2014, NABWT developed a mentoring program through which finalists of the Farah competition will serve as "entrepreneurship ambassadors" for other women.

ADB is also providing training and grants to assist vulnerable women to launch businesses under two CAREC projects: along the Ayni-to-Uzbekistan border highway (training on business development, financial management, and business plan writing) and in Tursunzade (training plus 135 conditional grants from $\$ 1,000$ to $\$ 5,000)$.

a Government Resolution No. 579, 05 December 2013, On the Establishment of Presidential Grants for Women's Entrepreneurship 2011-2015.

b Statement of Mahfirat Khidirzoda, Head of the Committee on Women and Family Affairs of Tajikistan. Farah-2014 Journal. Khujand: National Association of Business Women of Tajikistan (NABWT). p. 79.

CAREC $=$ Central Asia Regional Economic Cooperation, NABWT = National Association of Business Women of Tajikistan.

\section{E. Transport}

Tajikistan is a landlocked country with a landscape dominated by mountains. Most of the population lives in rural areas, and so functioning transport links are vital to their ability to access employment opportunities and social services. The country inherited its road and transport infrastructure from the Soviet period, and the system was in need of repair before independence was declared. Damage from the civil war, heavy use, and natural events have caused the roads to deteriorate further. In Tajikistan, cross-border travel and trade are also complicated by border points between neighboring Uzbekistan and the Kyrgyz Republic often being closed due to political relations.

$\mathrm{ADB}$ is the largest multilateral development partner in the Tajikistan transport sector and projects aimed at reducing poverty and isolation under the Central Asia Regional Economic Cooperation (CAREC) Program have focused on building and rehabilitating major highways, modernizing border crossings, and improving rural roads. The Living Standards Improvement Strategy for Tajikistan for 2013-2015 prioritizes transport and communications infrastructure with recommended actions that have a gender dimension in for instance, facilitating entrepreneurship and access to markets, and increasing security on transport and road safety. The strategy, however, articulates expected outcomes that can be measured primarily in terms of quantifiable outputs (e.g., kilometers of improved roads) without considering links between the gender disparities articulated in a subsequent chapter, women's limited mobility, and women's needs in terms of road use and transport. Three ADB projects under the CAREC Program have Gender Action Plans (GAPs) to ensure that women benefit fully from the projects and also that their priority concerns are 
taken into consideration. The GAPs anticipate gender-sensitive road design and safety features, means to improve women's livelihoods (both enhancing women's opportunities to start businesses and expanding employment within the sector), and training on health issues (mainly, AIDS prevention, diagnosis, and treatment).

\section{Baseline Data and Gender-Sensitive Indicators}

Unfortunately, there is little information or data about gender-related patterns of road use and travel in Tajikistan, such as the number of male and female drivers, public transport use disaggregated by sex, or accessibility of urban transport for women and men in terms of cost and timetables, and including such groups as single parents, the elderly, PWDs, and rural users. Sex-disaggregated employment data within the transport sector, or in associated educational specializations, are very general. Likewise, no studies emerged during this assessment that include qualitative information about transport infrastructure inefficiencies with respect to male and female entrepreneurs who engage in trade or even other forms of business. Development projects assume that construction and rehabilitation of roads will improve women's lives and expand their opportunities; however, without baseline data, it may be very difficult to demonstrate a clear effect. At the same time, gender-sensitive indicators are needed to measure the impact of transport projects on women's lives. The GAPs that relate to ADB transport projects include quantitative indicators (e.g., number of women trained, percentage of jobs allocated to women, number of safety features constructed, etc.). Qualitative indicators are also needed to determine the extent to which women and girls are benefiting from improvements, taking advantage of new opportunities, are engaged in transport issue decision making, and, potentially, any adverse effects on the female population.

\section{Gender Differences in Mobility and Travel}

FGDs held for this assessment provided insights into women's travel patterns. Because women are much less likely to be in full-time formal employment than men, especially in rural areas, their travel tends to be more varied and connected to household responsibilities. Women frequently travel with children, and they go to health care facilities, to schools, to visit relatives, and sometimes to local government offices, as well as in connection with work in petty trade and markets. No women mentioned driving cars, although FGD participants in Nau noted that, thanks to remittances, many families have been able to purchase vehicles. A 2012 nationwide survey confirmed that car ownership has almost doubled in the last decade (31\% of households own a car or truck, compared to 17\% reporting car or truck ownership in 2005). Rural households are more likely to have a vehicle than urban households. ${ }^{449}$ Even in households that own cars, women usually do not drive as is suggested by the number of households headed by males having cars in 2007 being twice the number of households headed by females. ${ }^{40}$ Women rely on male family members or take marshrutki (private microbuses) and taxis, rather than publicly-owned transport. According to an FGD participant in Garm, there is no bus or marshrutki service from her village to the nearest health care center because these vehicles cannot manage the roads; private taxis are the only option. Women farmers in a Kurgan-Tyube focus group reported that they take marshrutki to their land plots or, when these are not available, they walk.

449 Tajikistan Demographic and Health Survey 2012, p. 20.

450 Tajikistan Living Standards Measurement Survey 2007, p. 125. 
Limits on women's mobility also impinges on other freedoms. As noted in a following section on girls' access to education, dilapidated roads, lack of transport, and concerns over the safety of adolescent girls traveling alone all contribute to girls' absenteeism. Further, these all contribute to the high number of home deliveries, especially in winter when roads from villages to district hospitals become blocked with snow. ${ }^{451}$

Girls and women also face social constraints to mobility that are closely linked to gender norms. Some FDG participants reported that young wives are often denied permission to visit relatives or friends and have no independent income to travel. Women whose husbands or other family members are migrants appear to have more autonomy and mobility, as they are required to take on new nondomestic responsibilities, but even then women generally seek their husband's permission for long-distance travel. Respondents to this assessment noted that few young rural women would continue their higher education in Dushanbe or other cities, in part due to their families not permitting them. The link between perceptions about women's safety, the social acceptability of women traveling independently, and current transport options warrants greater attention. Still, in future transport projects, consideration should be given to promoting female mobility, by, for example, increasing safety features, such as priority seats for women (especially for women with children), employing more female staff (especially for long-distance travel), constructing bus stations and waiting areas that are safe for women, and using campaigns to improve public confidence in new transport options.

\section{Women's Priorities in Road Construction Projects}

When women in FGDs were asked about what should be addressed in road construction and rehabilitation projects, they singled out unimproved small feeder roads between villages and safety issues associated with both the old and new roads. The former contrasts with the rehabilitation of large national highways, especially those between provinces and connecting border regions, which has previously been a priority in Tajikistan. One FGD participant in Nau gave an example in which the local population collected money as part of the 2007 Year of Road Reconstruction, though ultimately the money was spent to repair the main district-level roads and not the ones residents felt were in the worst condition. Panjakent and Garm FGD participants explained that it is generally easier to travel to district centers than between villages. Women prioritized repair of small feeder roads as these are the ones they use most often and which would most improve their access to income-generating activities.

Of paramount importance to women is ensuring safety on and near roads, especially regarding children. Women in all transport issue focus groups mentioned concerns over high traffic near schools. Features they felt should be essential to road rehabilitation and construction projects included clear signage, sidewalks, barriers between the road and the sidewalk, pedestrian crosswalks, and traffic lights. Participants who attended an FGD in Dushanbe emphasized the need for greater speed controls (specifically, erecting speed limit signs and speed cameras and levying fines for speeding) as they felt drivers are unused to newly asphalted roads and they "do not feel the speed" now that the roads are in better condition. Of note, Panjakent FGD participants spoke about plans to create a large

451 Gender and Youth Study in Rasht Valley, p. 21 
bazaar and mentioned that they preferred it were located outside of the town center, with good transport links, in order to limit the number of trucks on local streets. Other security features that are important for women travelers include streetlights, well-lit bus shelters with protection from the weather, and having adequate staff, including female staff, on public transportation and at stations.

A representative of a women's DPO described the specific concerns that people with disabilities have about dangerous road and pavement design, which are especially relevant to women as they are more likely to accompany children with disabilities (as well as women who use prams or strollers). Previously repaired crosswalks have high steps at both ends, bus shelters have been placed behind road barriers, there are few places with dropped curbs or ramps, and there are very few audible signals. Public transportation that is accessible to people with disabilities, with wide doors or lifts, is not available. Girls and women with disabilities, in particular, report that they do not like using private taxis because they are uncomfortable being lifted inside by male drivers.

Another priority area for women is ancillary services to make travel more comfortable. Road construction should be supplemented by rest stops that have toilet facilities for males and females, as well as special family rooms to feed children, change diapers, etc. Women in rural areas especially are reluctant to venture from their own communities, "due to the lack of safe and secure sanitation facilities in public places." ${ }^{\prime 252}$ Other priority services include hotels and cafes along the roadside. More than one expert interviewed for this assessment highlighted that in order to mainstream gender in transport projects that are part of larger urban development schemes, or even social services access projects, road construction should be accompanied by funding for local services themselves. Support for the creation of shelters and crisis centers that women can access in their communities is especially critical.

Because women are largely absent from decision-making positions in the transport sector (for example, only $11 \%$ of department heads in the Ministry of Transport are women), ${ }^{453}$ their priorities and views on projects may not be taken into consideration. ADB encourages women's participation in road enhancement project community consultations, ${ }^{454}$ and Panjakent FGD participants confirmed that women have taken part in such meetings. Such special measures are a very important means of giving women a voice in projects that will affect their lives directly, but they are also a stop-gap solution. In parallel, further efforts should be made to ensure that such public consultations become standard procedure in local development projects and also that barriers to women assuming formal transport sector decision-making roles are removed.

452 Gender Assessment: SDC Rural Drinking Water Program in Tajikistan, p. 6. 


\section{Economic Opportunities for Women}

One important benefit of improved roads (and also the creation of roadside infrastructure) is that they provide women with employment and income-generating activities. One of ADB's transport projects includes strengthening human resource management in the implementing organization and the Ministry of Transport to increase women's employment opportunities. Though data about the number of women currently employed in either of these organizations or in which positions are limited, generally, the transport and construction industries are male-dominated. Fourteen percent of Ministry of Transport employees are women. ${ }^{455}$ Women are better represented as employees and small business owners in transport, storage, and communications (which are aggregated in national statistics) than they are in construction. Still, the average number of women employed in these fields annually is less than half the average number of men, and women make up only $14 \%$ of allied entrepreneurs. ${ }^{456} \mathrm{Few}$ women are employed in construction; on average 1 in 10 employees is a woman, and 9\% of owners of small construction businesses are women. ${ }^{457}$ In terms of future specialists, there were 17 female students in "transport operations" in secondary vocational institutes during the 2013-2014 academic year, and 48 female students studying construction and architecture combined. ${ }^{458}$ It is significant that focus group participants (notably in Panjakent and Nau) felt that there are no particular stereotypes that would preclude women being employed as taxi or truck drivers, and it is worth exploring how women could be encouraged to enter this job market. Without special measures to increase the number of women working in relevant fields, it is unlikely that women will benefit to the same extent as men from job creation and employment opportunities related to ADB transport projects.

There is also potential that female entrepreneurs, especially those engaged in trade and services can benefit from improved roads and roadside infrastructure. GAPs under ADB transport projects include training for women on business development, ${ }^{459}$ and a conditional grants fund (administered by the Women's Committee and based on criteria used under a presidential business grants scheme). ${ }^{460} \mathrm{It}$ is essential to ensure that there is adequate and safe roadside infrastructure to support such businesses and, in addition, that any new or renovated business spaces are accessible to women in terms of safety and affordability. The following case study illustrates the specific transport-related issues that women engaged in market trade face that should be given consideration in projects to empower women economically.

455 Women and Men of the Republic of Tajikistan, p. 114.

456 Ibid. pp. 91,100

457 Ibid. pp. $90,99$.

458 Ibid. p. 79

459 Under CAREC Corridor 3 (Dushanbe-Uzbekistan Border) and CAREC Corridor 3 and 5 Enhancement.

460 Only women entrepreneurs from Tursunzade are eligible to apply for grants under CAREC Corridor 3. 


\section{Box 8: Transport-Related Issues for Women Market Traders}

Selling in open markets has increasingly become a means for women to earn an income, especially as many men have left the field due to declining revenues. In Sughd province, markets empower almost 15,000 entrepreneurs, $83 \%$ of whom are women. ${ }^{a}$ A safety audit of Sughd open market revealed many difficulties and risks, but only findings concerning transport are summarized here. Two types of female traders are especially vulnerable and unprotected: "shuttle traders" who export goods from Uzbekistan and resell them in Tajikistan, and women who sell from roadsides, pavements, and near pedestrian crossings because of limited expensive market stalls. Women who work at roadsides are microentrepreneurs who usually sell home-produced goods such as fruit, greens, milk, eggs, bread and other products, and they expressed the greatest anxiety about the safety of their goods and poor treatment by market administration and police. ${ }^{\mathrm{b}}$

Surveyed women from six markets mentioned dissatisfaction with the infrastructure, including the roads leading to the markets that are in need of major repairs. ${ }^{c}$ In terms of transport security, very few women entrepreneurs use private transport to reach markets; most walk or use marshrutki, depending on the time of day and the goods they are transporting. During the day, almost all women walk to markets (except those selling eggs and dairy products) and report feeling safety. In evening, they are more likely to use marshrutki if they can afford it, because they are tired and concerned about the safety of their earnings. Most women who transport larger goods only every two weeks hire taxis. Some of the safety issues on marshrutki that women highlighted were the driver's noncompliance with traffic rules, erratic traffic, crowded minibuses and fears about pickpockets. Female traders with safety concerns try to finish work while there is still daylight or they are accompanied by male relatives. ${ }^{\mathrm{d}}$ High transport costs were also mentioned as a factor that impedes delivering goods to market. The respondents reported that they are most at risk for theft on public transport and when they have to walk a long distance from bus stops to their homes. Women who engage in cross-border shuttle trade felt the greatest danger of theft or loss of goods when at border crossings, but this is also dependent on the individual woman's knowledge of transport regulations and tariffs. ${ }^{\text {e }}$

a National Association of Business Women of Tajikistan. 2010. Safe Markets and Cross-Border Trade for Women in Tajikistan. Khujand. p. 2.

b G. Sharipova. and I. Babajanova. 2010. The Safety of Women Entrepreneurs at Markets: Results of a Safety Audit. Khujand: National Association of Business Women of Tajikistan. pp. 3, 6. [in Russian]

c Ibid. p. 16.

d Ibid. pp.17-18.

e lbid. pp. 20-21.

Attention should also be given to ensuring that road improvements do not unintentionally increase women's uncompensated workload. At present, women and girls may be exempted from some of this labor due to dangerous road conditions or lack of reliable transport.

\section{Gender Dimensions of Road Safety}

Road safety is a concern for drivers, pedestrians, and for populations who live along major roads and use public transport. As noted above, women express particular concern for their children's safety due to the lack of sidewalks, roadside barriers, pedestrian crossings, and posted speed limits. There are also gender differences in road safety and health, but these have not been explored in depth in Tajikistan. According to the World Health Organization, the 2009 mortality rate from traffic injuries in Tajikistan was 6.1 per 100,000 population, about half the European regional average. ${ }^{461}$ Sex-disaggregated data from 2007 showed that men were much more likely to die in road accidents than women (78\% of 
fatalities were among males). ${ }^{462}$ Most fatalities are among pedestrians (42\%), followed by vehicle passengers (30\%) and drivers (23\%). ${ }^{463}$ Greater attention should be given to the reasons behind the high male accident and fatality rates, and messages targeting males (as drivers and pedestrians) should be included in road safety campaigns and educational programs. 


\section{Entry Points for Gender Mainstreaming}

240. This final chapter outlines several general approaches for integrating a gender perspective in project planning and implementation, as well as entry points for the critical gender issues identified herein. This section also lists entry points for gender mainstreaming in the sectors where ADB anticipates projects under its country partnership strategy for 2015-2019.

\section{General}

- Review national gender equality policy and strategies and reinforce government commitments during negotiations, project design, implementation, and monitoring and evaluation.

- Ensure that the Women's Committee engagement with the national machinery for the promotion of gender equality/women's empowerment is not limited to the central office during project design and implementation, but includes local Committee representatives and ministerial gender focal points.

- In all projects, ensure that data are sex-disaggregated, and include gender-sensitive information in the collection of baseline data, project monitoring, and collection of endline data.

- Strengthen the capacity of implementing agencies and other key stakeholders to mainstream gender when conducting preliminary assessments, project planning, and monitoring and evaluation (including collection, analysis, and use of sexdisaggregated data for evidence-based planning).

- Ensure that activities directed at empowering women do not create additional burdens or increase women's workload. In addition to projects that target women, promote activities that equalize the distribution of domestic chores.

- Review all projects to ensure that they do not reinforce gender stereotypes and take steps to eliminate those that persist wherever possible.

- Promote the meaningful participation of women in discussions, design, and implementation of development projects. This should not be limited to ad hoc consultative processes, but should include measures to institutionalize a system 
in which women are part of discussions about local planning and have a role in overseeing their implementation.

- When undertaking consultations with women or women's groups, ensure diversity, with different socioeconomic groups, ages, and ethnicities being represented, as well as women with disabilities, single mothers, and women who head households.

\section{Political and Civic Participation}

- In meetings and negotiations with government bodies, reinforce Tajikistan's own commitments to increase the number of women in government positions by calling for diversity in the composition of teams.

- When possible, engage with female officials and specialists in relevant sectors and especially in local government offices as resources for ADB projects.

- Consult with women's civil society organizations (CSOs) on project design, implementation, and monitoring, and include such NGOs in any inter-agency teams or meetings.

- Support capacity-building for women's CSOs regarding engaging with government representatives. In parallel, encourage local administrations to collaborate with women's nongovernment organizations (NGOs) in the community.

\section{Economic Opportunities}

- Analyze the extent to which ADB project investments will create opportunities for women to engage in income generation and become employed. Identify how labor market segregation may result in women not benefiting from these opportunities.

- Implement measures to ensure women benefit fully, for example, campaigns to address gender stereotypes and discrimination in a particular sector, workplace training, policies that help to balance work and family obligations, etc.

\section{Social Development}

- Support research and analysis of the gender-specific health impacts related to lack of transport to health facilities, energy poverty or use of unclean energy sources, and lack of access to clean water, and the potential benefits that could result from ADB infrastructure projects.

- Consider ways to include informational and education activities on HIV and sexually transmitted infection prevention within ADB projects, for example, messages 
targeting youth in technical and vocational education and training projects and targeting men in transport projects.

- Include measures to increase women's personal security within ADB infrastructure projects, for example, through improved street lighting, bus shelters, public transportation, public toilets, and accessible safety features (public telephones, crisis centers, shelters).

- Assess the economic costs of gender-based violence to the state budget. Analysis should address the cost of preventative measures and provision of comprehensive services for victims/survivors, and should be used in national and local budget planning.

- Develop and implement awareness campaigns and training aimed at increasing women's knowledge of their labor rights, especially for those engaged in agricultural work, and how to protect their rights.

- In addition to providing women with information about their legal rights through ADB projects, design and implement activities that target men with messages about the role they can play in protecting women's rights (e.g., girls' rights to inheritance, property ownership, etc.).

\section{Agriculture and Natural Resources}

- Build the capacity of the State Statistics Agency to produce sex-disaggregated data that is also disaggregated by rural and urban residence in order to improve understanding of the issues that rural women face.

- Develop and implement strategies to increase women's formal employment in agriculture and to assume managerial roles.

- Engage with farm managers directly to encourage them to make gender-sensitive working condition improvements and to follow a practice of formal employment of women.

- Ensure that domestic as well as agricultural and industrial water needs and uses are addressed in sector analyses and strategies.

- In order to establish baseline data, conduct needs-assessments and/or household surveys to identify women's roles in water collection, storage, and disinfection. Research should examine how women are impacted by water insufficiencies, in terms of additional time spent on housework or complicating home-based production, as well as health impacts.

- Identify the barriers to women's participation in water users' associations (formal barriers as well as those related to time burdens and gender stereotypes), as well 
as the potential role that women could play in local water management in order to develop strategies to increase women's participation.

- Develop and run informational and educational campaigns on climate change and agricultural adaptation strategies that target women, and provide support to women to access the resources needed to implement such strategies.

- Engage with women and women's NGOs to share best practices about natural resource management, conservation, and local climate change adaptation, and ensure that women with the relevant expertise also occupy decision-making positions on official climate change delegations.

\section{Education}

- In project planning and implementation, develop comprehensive approaches that address gender inequalities and barriers to education (e.g., activities to improve the gender sensitivity of relevant officials or to increase the number of women in positions of authority in education).

- Review existing studies of out-of-school girls and develop and implement projects that address some of the factors behind their absenteeism (i.e., lack of transportation options, inadequate toilet facilities). Additionally, increase support for teachers and women's NGOs to work directly with parents and local authorities to improve retention of girls.

- In the area of TVET, undertake studies to more precisely showcase gender gaps and to understand the educational experiences of girls. Design and implement projects that address institutional barriers (i.e., lack of dormitories for girls, limited transport options), segregation in academic subjects, and gender stereotypes (i.e., that education is "less desirable" for females).

- Build the capacity of the executing agencies-in connection with core operational sectors, such as construction, transport, and energy supply-to encourage young women to enter nontraditional fields of study by using special initiatives such as scholarships, internships, or mentoring programs.

- Dedicate resources to publicity campaigns to promote education for girls, including girls with disabilities, and to encourage girls and women to study nontraditional subjects.

\section{Energy}

- In order to establish baseline data, conduct needs-assessments and/or household surveys to identify women's specific energy needs in Tajikistan and how they are currently being met. Research should examine how women are impacted by energy 
supply problems, in terms of additional time spent on housework, on preparing solid fuel, or complicating home-based production as well as health impacts.

- Ensure that consultation processes in the energy sector include women's meaningful participation, not only in terms of household energy saving, but also relevant to policy setting and planning.

- Engage with women's organizations and environmental organizations that include women in green energy projects as a means to gain insights into women's energy needs and also to identify potential agents of local change.

- Ensure that women, not only those from households headed by females, and men are reached with information and training about energy technologies, labor-saving devices, energy efficiency in the home, etc.

- Consider undertaking a specialized study to determine the impact of energy insufficiencies on women's businesses in order to develop specialized services, loans, lines of credit, grants, etc.

- Develop links with educational/TVET institutions and energy sector key employers to increase the number of women entering related fields of study and professions, with particular attention to training women in renewable energy.

\section{Entrepreneurship and Small and Medium-Sized Enterprise Development}

- Develop a unified and sex-disaggregated system of classifying and counting businesses and promote the use of consistent criteria to define a “women's enterprise" for purposes of development projects, loans, microfinance, grants, etc.

- Support data analysis and qualitative studies (i.e., focus groups) of the profiles of female and male entrepreneurs (i.e., size of business, sector, number of employees, etc.) in order to map how women are engaged in businesses in Tajikistan.

- Involve women working in the private sector (employers and employees, and those in business associations) and gender equality advocates (in government and civil society) in discussions of such topics as taxation and business regulation reform options.

- Encourage banks and financial institutions to identify any gender differences in access to financial products and services and to take steps to address factors that create barriers for specific groups of women (i.e., rural women, women farmers, abandoned wives of labor migrants, etc.).

- Work with women across the business hierarchy, from individual entrepreneurs to women who own or manage larger businesses. Identify key female business personnel in varied sectors and sponsor them to become mentors to other female entrepreneurs and support them in developing women-friendly workplaces. 
- Support the development and expansion of specialized mechanisms, such as concessional loans, business incubators, and business support centers, that would reach a greater number of women in business.

- Develop better links between infrastructure projects (particularly concerning energy and water supply) and those supporting women's entrepreneurship in order to create conditions that will assist women to start and expand their businesses.

- Support business advisory services and training programs tailored to the needs of both those women starting businesses and those with established businesses and link training programs to specialized loans, microfinance, or grants for female entrepreneurs. Ensure that business services, training programs, and finance are accessible to women with disabilities.

- Disseminate success stories that promote women as role models in business.

\section{Transport}

- Improve the collection of sex-disaggregated data and gender-specific information relevant to transport planning (i.e., transport needs, modes and costs, routes and schedules).

- Conduct consultations to identify gender-specific issues and priorities relevant to women's and men's transport needs. Ensure that the specific views of persons with disabilities, especially women those who care for them, are given special consideration.

- Consider options to improve local and feeder roads in project areas.

- Explore options for public transport that would improve the mobility of girls and women, especially to and from educational institutions, taking into consideration costs, schedules, safety, etc.

- Build the capacity of transport policymakers to undertake gender mainstreaming and promote focal points in relevant government agencies.

- Create opportunities for income generation and employment for women and ensure that transport options meet their needs. Provide support to female entrepreneurs to develop and/or expand transport services.

- Identify the key barriers to women working in the transport industry, including the influence of gender stereotypes and discrimination. Develop links with educational/ TVET institutions and key employers to increase the number of women entering fields of study and professions related to transport.

- Develop equal opportunity strategies for transport sector employment (i.e., recruitment, hiring and promotion practices, training and workplace conditions, policies on sexual harassment). 


\title{
Appendixes
}

\section{Appendix 1: Key Legal and Policy Developments}

\author{
Laws \\ Law on State Guarantees of Equal Rights and Opportunities for Men and Women (2005) \\ Law on the Protection of Breastfeeding Children (2006) \\ Law on State Social Orders (2008) \\ Amendment of the Family Code of the Republic of Tajikistan raising the legal marital age from 17 to 18 years (2010) \\ Law on the Prevention of Domestic Violence (2013) \\ Law on Combating Human Trafficking and Assisting Victims of Trafficking (2014)

\section{National Policies, Programs, and Strategies}

- State Program on the Main Directions of State Policy to Ensure Equal Rights and Opportunities for Men and Women in the Republic of Tajikistan for 2001-2010

- National Development Strategy of the Republic of Tajikistan to 2015

- Poverty Reduction Strategy of the Republic of Tajikistan for 2007-2009

- Poverty Reduction Strategy of the Republic of Tajikistan for 2010-2012

- Living Standards Improvement Strategy of Tajikistan for 2013-2015

- Comprehensive Program to Combat Trafficking in Persons for 2006-2010 and another for 2011-2013

- Regulations for establishing support and aid centers for victims of human trafficking

- Model regulation on support centers for victims of human trafficking

- Policy on the Procedure for Awarding Presidential Grants to support the development of small and medium-sized enterprises, encourage women and girls to seek career guidance, raise awareness of the law and create new jobs for 2006-2010

- Establishment of Presidential Grants in entrepreneurship among women for 2008-2010

- Policy on the procedure for awarding Presidential Grants in entrepreneurship among women for 2011-2015

- Quota of the President of the Republic of Tajikistan for admission of students to higher educational institutions for 2006-2010

- Quota of the President of the Republic of Tajikistan for admission of students to higher educational institutions

- State Program for the Education, Selection and Placement of Capable Women and Girls in Leadership Positions for 2007-2016

- National Action Plan for Safe Motherhood in the Republic of Tajikistan to 2014

- National Strategy for Enhancing the Role of Women in the Republic of Tajikistan for 2011-2020

- State Program for the Prevention of Domestic Violence for 2014-2023

Source: Government of Tajikistan. 


\section{Appendix 2: Definitions of Gender and Development Terms}

This country gender assessment uses several terms relevant to gender and development. Some development organizations and international financial institutions have their own definitions of these terms, but the Asian Development Bank (ADB) generally relies on commonly accepted meanings. Where possible, the list below includes definitions from ADB policy documents. As meanings change over time, vary by organization, and are also dependent on context, the definitions are illustrative and are not intended to be definitive.

Domestic violence (also called "intimate partner violence") refers to behavior in an intimate relationship that causes physical, sexual, or psychological harm, including physical aggression, sexual coercion, psychological abuse, and controlling behaviors.'

Empowerment describes both the process and the outcome of people-women and mentaking control over their lives: setting their own agendas, gaining skills (or having their own skills and knowledge recognized), increasing self-confidence, solving problems, and developing self-reliance. Empowerment implies an expansion in women's ability to make strategic life choices in a context where this ability was previously denied to them. In most cases, the empowerment of women requires transformation of the gendered division of labor and of society. ${ }^{2}$

Gender refers to the sociologically and culturally based distinction between men and women. One's gender is therefore most often composed of those roles and attributes that are not purely "natural" or biologically determined, but are rather dictated by norms and traditions. Because gender is not biologically given, the attributes of both male and female gender can change over time and across cultures. ${ }^{3}$

Gender analysis is a key strategy of ADB's gender mainstreaming approach that involves systematically assessing the impact of a project on men and women, and on the economic and social relationship between them. ${ }^{4}$

Gender-based violence (GBV) was first defined by the UN Declaration on the Elimination of Violence against Women as an alternative term for "violence against women" to refer

WHO. 2011. Intimate Partner and Sexual Violence against Women. Fact Sheet No. 239. http://www.who.int/mediacentre/factsheets/ fs239/en/index.html

2 Mediterranean Institute of Gender Studies. 2009. Glossary of Gender-Related Terms 6-7, http://www.medinstgenderstudies.org/ publications/glossary-on-gender

3 UNDP. 2007. Gender Mainstreaming in Practice: A Toolkit (3rd Edition). Bratislava: UNDP. p. 125.

4 ADB. 2003. Gender and Development. Manila. p. 39. 
to any act that results in, or is likely to result in, physical, sexual, or psychological harm or suffering to women, including threats of such acts, coercion, or arbitrary deprivation of liberty, whether occurring in public or in private life. ${ }^{5}$ Over time, the definition has evolved to refer to any harm that is perpetrated against a person's will; that has a negative impact on physical or psychological health, development, and identity; and that is the result of gendered power inequities that exploit distinctions between males and females, among males, and among females. Although not exclusive to women and girls, GBV principally affects them across all cultures. Violence may be physical, sexual, psychological, economic, or sociocultural. ${ }^{6}$

Gender and Development (GAD) is a development approach that concentrates on the unequal relations between men and women due to "uneven playing fields." The term "gender" as an analytical tool arose, therefore, from an increasing awareness of inequalities due to institutional structures. It focuses not only on women as an isolated and homogeneous group, but on the roles and needs of both men and women. Given that women are usually in a disadvantaged position as compared with men, promotion of gender equality implies an explicit attention to women's needs, interests, and perspectives. The objective, then, is the advancement of the status of women in society, with gender equality as the ultimate goal. ${ }^{7}$ ADB describes gender and development as a crosscutting issue with relevance for and influencing all economic, social, and political processes. ${ }^{8}$

Gender discrimination refers to any distinction, exclusion, or restriction made on the basis of socially constructed gender roles and norms that prevent a person from enjoying full human rights. ${ }^{9}$

Gender equality is a desired result of gender equity and refers to equal opportunities and outcomes for men and women. ${ }^{10}$

Gender equity is a process for achieving the goal or outcome of gender equality. ADB includes gender equity as one of the five drivers of change in its long-term strategic framework, Strategy 2020.11

Gender mainstreaming is the process of assessing the implications for women and men of any planned action, including legislation, policies, or programs in any area and at all levels. It is a strategy for making the concerns and experiences of women, as well as of men, an integral part of the design, implementation, monitoring, and evaluation of policies, programs, and projects in all political, economic, and societal spheres so that women and men benefit equally, and inequality is not perpetuated. ${ }^{12}$

5 UN General Assembly. 1993. Declaration on the Elimination of Violence against Women. Resolution A/RES/48/104. Article 1. http://www. un.org/documents/ga/res/48/a48r104.htm

6 Council of Europe, 2007. Gender Matters: Manual on Gender-Based Violence Affecting Young People. Budapest. p. 43. http://eycb.coe.int/ gendermatters/contents.html

7 European Commission. 2004. Glossary of Gender and Development Terms. Toolkit on Mainstreaming Gender Equality in EC

Development Cooperation. Brussels: EuropeAid Cooperation Office. p. 2.

Gender and Development, p. 28.

Glossary on Gender-Related Terms, p. 2.

10 ADB. 2010. Country Gender Assessment: Bangladesh. Manila. p. vii.

11 Ibid.

12 Ibid. 
Gender sensitivity is a key strategy of ADB's gender mainstreaming approach that involves observing how ADB operations affect women and men, and taking into account women's needs and perspectives in planning its operations. ${ }^{13}$

National machinery (for the advancement of women) is the central policy-coordinating structure inside the government, whose main task is to support government-wide mainstreaming of a gender equality perspective in all policy areas. ${ }^{14}$

Sex refers to the biological characteristics that distinguish human beings as female or male.

Sexual harassment is unwanted conduct of a sexual nature or other conduct based on sex affecting the dignity of women and men at work, including the conduct of superiors and colleagues. ${ }^{15}$ 


\section{References}

Abdulloev, M. 2013. Gender Aspects of Agriculture. Agency for Statistics under the President of Tajikistan. Dushanbe.

Abdurazakova, Dono and Jessica Gardner. 2012. Gender Statistics in the Southern Caucasus and Central and West Asia: A Situational Analysis. Manila: Asian Development Bank (ADB).

Aga Khan Foundation Tajikistan. 2014. Gender and Youth Study in Rasht Valley. Dushanbe.

Agency for Statistics under the President of Tajikistan. 2007. Tajikistan Multiple Indicator Cluster Survey 2005. Final Report. Dushanbe.

—. 2009. Women and Men of the Republic of Tajikistan. Dushanbe. [Russian version].

—. 2010. Women and Men of the Republic of Tajikistan. Dushanbe. [English version].

_- 2012. Population and Housing Census of Tajikistan 2010. Volume III. National composition, language and citizenship of the population of the Republic of Tajikistan. [Russian version].

_- 2012. Women and Men of the Republic of Tajikistan. Dushanbe. [Russian version].

—. 2014. Tajikistan in Figures. Dushanbe.

—_. 2014. Women and Men of the Republic of Tajikistan. Dushanbe. [Russian version].

—_. 2014. Gender Statistics Database, available from http://www.stat.tj/ru/gender/ generbazeng/

- 2015. Gender Indicators in Dekhan Farming. Dushanbe.

__ Ministry of Health and ICF International. 2013. Tajikistan Demographic and Health Survey 2012. Dushanbe, Tajikistan, and Calverton, Maryland.

—_ and United Nations Children's Fund (UNICEF). 2009. Tajikistan Living Standards Measurement Survey 2007. Dushanbe.

Amjad, Shazia. [no date]. Out-of-School Girls: Challenges and Policy Responses in Girls' Education in Tajikistan. Dushanbe: UNICEF. 
Amnesty International. 2009. Violence is Not Just a Family Affair. Women Face Abuse in Tajikistan. London.

Asian Development Bank (ADB). 2000. Women and Gender Relations in Tajikistan: Country Briefing Paper. Manila.

_._. 2003. Gender and Development. Manila.

__. 2006. Country Gender Assessment: Republic of Tajikistan. Manila.

_.2010. Country Gender Assessment: Bangladesh. Manila.

_.2011. Civil Society Briefs: Tajikistan. Manila.

- 2013. Tajikistan: 15 Years of Partnership with the Asian Development Bank, Development Effectiveness Brief. Manila.

_ 2013. G0352 TAJ: Building Climate Resilience in the Pyanj River Basin. Manila.

_. 2014. Country Operations Business Plan for Tajikistan 2015-2017. Manila.

. 2014.TA 6143 Promoting Gender Equality and Women's Empowerment: Training and Awareness-Raising for Rural Women on Rights, Family Law, and Access to Legal Assistance. Consultant's Report. Manila.

Association of Microfinance Organizations of Tajikistan (AMFOT). 2013. AMFOT Members Statistical Data Analysis for the Reporting Period of 01 January to 31 December 2013. Dushanbe.

- 2014. Activity Analysis of AMFOT for the 4th Quarter of 2014. Dushanbe.

Azevedo, Joao Pedro, Atamanov, Aziz and Rajabov, Alisher. 2014. Poverty Reduction and Shared Prosperity in Tajikistan: A Diagnostic. Policy Research Working Paper 6923. Washington, DC.: World Bank.

Billimoria, Raiomand and Ergashev, Adkham. 2010. Incorporating Gender Activities into Cotton Lending Project Design: High Impact at Reasonable Cost. Washington DC.: International Finance Corporation.

Bobokhanova, Muyasara, Chair of the Association of Women and Society. 2011. The Path to Developing Women's Entrepreneurship in Rural Areas of Tajikistan. (Presentation, UNECE Policy Seminar on Women's Entrepreneurship Development in Central Asia, Geneva, 19 September 2011).

Bozrikova, Tatiana. 2011. Business Environment Assessment of Female Entrepreneurship in Tajikistan. Geneva: United Nations Economic Commission for Europe (UNECE). 
Bozrikova, Tatiana and Bazidova, Zarina. 2014. Situational Analysis Report: the Impact of Migration on the Socio-economic Vulnerability of Rural Women in Tajikistan. Dushanbe: United Nations Entity for Gender Equality and the Empowerment of Women (UN Women).

Bureau on Human Rights and Rule of Law, Disabled Women's League "Istirok", and UN Women. 2011. Implementation of the Rights of People with Disabilities in Sughd Province, Republic of Tajikistan. Report on Monitoring Outcomes. Chapter 1. Khujand. [in Russian]

Care International. 2010. Climate Change Brief: Adaptation, Gender and Women's Empowerment.

Central Intelligence Agency. CIA World Factbook: Tajikistan. https://www.cia.gov/library/ publications/the-world-factbook/geos/ti.html

Centre for Mental Health and HIVAIDS, Tajik Network of Women Living with HIV and Guri Surkh. 2013. Alternative Report on Implementation of the UN Convention on the Elimination of All Forms of Discrimination against Women. Dushanbe.

Coalition of Public Associations "From de Jure Equality to de Facto Equality." 2009. The State Program "Basic Directions of State Policy to Ensure Equal Rights and Opportunities for Men and Women in the Republic of Tajikistan for 2001-2010": Progress Evaluation Based on Public Monitoring Results. Dushanbe.

_- 2012. The Second Shadow Report on the Realization of the Convention on the Elimination of All Forms of Discrimination against Women by Public Organizations of Tajikistan. Dushanbe.

Colombini, Manuela, Mayhew, Susannah H and Rechel, Bernd. 2011. Sexual and Reproductive Health Needs and Services for Vulnerable Groups in Eastern Europe and Central Asia. London School of Hygiene and Tropical Medicine/United Nations Population Fund.

Commissioner for Human Rights of the Republic of Tajikistan. 2011. Strategy for 2011-2015. Dushanbe.

Committee of Women's and Family Affairs. 2014. Press conference of the Committee on Women and Family Affairs under the Government of the Republic of Tajikistan. 30 July. http://kumitaizanon.tj/ru/news/id/150

Council of Europe, 2007. Gender Matters: Manual on Gender-Based Violence Affecting Young People. Budapest. http://eycb.coe.int/gendermatters/contents.html

Crestani, Franca. 2011. Torino Process 2010. Republic of Tajikistan. Turin: European Training Foundation. 
Danzer, Alexander, Dietz, Barbara and Gatskova, Ksenia. 2013. Tajikistan Household Panel Survey: Migration, Remittances and the Labor Market. Regensburg: Institute for East and Southeast European Studies.

Dar, Firdoos. 2013. The Role of NGOs in Independent Tajikistan. The International Journalof Not-for-Profit Law. Volume 15, Issue 1. Washington, DC.

Dar, Firdous Ahmad and Wani, Mohd Younus. 2012. Role of NGOs in the Development of Women in Post-Independent Tajikistan. The Journal of Central Asian and Caucasian Studies (OAKA) of the International Strategic Research Organization (USAK): Ankara. Vol. 7 No. 14. 149-176.

d'Hellencourt, Nouchine Yavari. 2007. Qualitative Survey on Issues in Girls' Education in Tajikistan: an in-Depth Analysis of the Reasons Girls Drop Out of School. Dushanbe: UNICEF.

Eurasia Foundation and Caucasus Research Resource Centers. 2011. Equal Before the Law? A Study of How Citizens Experience Access to Justice in Kazakhstan, Kyrgyzstan and Tajikistan. Washington, DC.

European Commission: EuropeAid Cooperation Office. 2004. Glossary of Gender and Development Terms. Toolkit on Mainstreaming Gender Equality in EC Development Cooperation. Brussels.

European Training Foundation. 2011. HCD Review. Relationship Between Human Capital Development and Equity in the Republic of Tajikistan. Turin.

Government of Tajikistan. 2011. National report submitted in accordance with paragraph 15 (a) of the annex to Human Rights Council resolution 5/1 (Universal Periodic Review process).

- 2012. Consideration of reports submitted by States parties under article 18 of the Convention on the Elimination of All Forms of Discrimination against Women, Combined fourth and fifth periodic reports. CEDAW/C/TJK/4-5.

- 2013. Implementation of the International Covenant on Economic, Social and Cultural Rights, Second and Third Periodic Reports. para. 17(b)

- 2014. National Review of the Republic of Tajikistan to Implement the Beijing Declaration and Platform for Action. Dushanbe.

Golobof, Alexandra, Weine, Stevan, Bahromov, Mahbat and Luo, Jing. 2011. The Roles of Labor Migrants' Wives in HIV/AIDS Risk and Prevention in Tajikistan. AIDS Care. Vol. 23, Issue 1. 91-97.

Gomart, Elisabeth. 2003. "Between Civil War and Land Reform. Among the Poorest of the Poor in Tajikistan." When Things Fall Apart Qualitative Studies of Poverty in the Former Soviet Union. Washington DC.: International Bank for Reconstruction and Development/ World Bank. 
Gramatikov, Martin and Kabir, Monjurul. 2013. Accessing Justice: Legal Aid in Central Asia and the South Caucasus. Bratislava: UNDP Regional Centre For Europe and the CIS.

Gravesteijn, Robin. 2012. Microfinance and Women Entrepreneurship: An Impact Assessment of a Start-up Loan Programme. Dushanbe, Tajikistan: IMON International.

Haarr, Robin. [2010. Safe Schools and the Reduction of School-Related Gender-Based Violence in Tajikistan: an Evaluation of Impact of Training on Teachers and Community Members. Dushanbe: Creative Associates International, Inc.

Habitat for Humanity Tajikistan. 2014. Needs Assessment/Baseline Survey Report (for ADB Access to Green Finance Project). Dushanbe.

Human Rights Center. 2013. Submission to the $108^{\text {th }}$ Session of the UN Human Rights Committee. Dushanbe.

Integrated Regional Information Networks (IRIN). 2004. Tajikistan: Civil war has left one in three women victims of domestic violence. Our Bodies - Their Battle Ground: Genderbased Violence in Conflict Zones. http://www.irinnews.org/pdf/in-depth/gbv-irin-indepth.pdf

International Bank for Reconstruction and Development and World Bank. 2012. Farmer and Farm Worker Perceptions of Land Reform and Sustainable Agriculture in Tajikistan. Washington DC.

International Federation for Human Rights (FIDH). 2014. Tajikistan: Drop draft legislation restricting NGO access to funding. 25 November. https://www.fidh.org/InternationalFederation-for-Human-Rights/eastern-europe-central-asia/tajikistan/16540tajikistan-drop-draft-legislation-restricting-ngo-access-to-funding.

FIDH and Anti-Discrimination Center Memorial. 2012. From Tajikistan to Russia: Vulnerability and Abuse of Migrant Workers and their Families.

International Finance Corporation. 2013. Enterprise Surveys: Tajikistan Country Profile. Washington, DC.: World Bank.

International Foundation for Electoral Systems (IFES). 2015. Elections in Tajikistan. 2015 Parliamentary Elections. Frequently Asked Questions. Washington, DC.

- 2010. Public Opinion in Tajikistan: 2010 Findings from an IFES Survey. Washington, DC.

International Labour Organization (ILO). 2009. Work and Family: The Republic of Tajikistan. Moscow.

2014. Maternity Protection and the Childcare Systems in Central Asia: National Studies in Kazakhstan and Tajikistan. Moscow. 
ILO Subregional Office for Eastern Europe and Central Asia. 2010. Migrant Remittances to Tajikistan: The Potential for Savings, Economic Investment and Existing Financial Products to Attract Remittances. Moscow.

International Organization for Migration (IOM). 2009. Abandoned Wives of Tajik Labor Migrants. Dushanbe.

Ishkanian, Armine. 2003. Gendered Transitions: The Impact of the Post-Soviet Transition on Women in Central Asia and the Caucasus. Perspectives on Global Development and Technology. 2 (3-4). Leiden: Koninklijke Brill NV.

Joint United Nations Programme on HIV/AIDS (UNAIDS). 2013. Research on Identifying the Needs and Problems of Women Living with HIV in Tajikistan. Dushanbe. [in Russian]

- 2014. Country Report on Progress in Preventing the HIV Epidemic. Tajikistan. [in Russian]

Juraeva Sh.A. Kast Kh.E. 2011. Tajikistan: Country Monitoring Report 2010. Democratic Ownership and Development Effectiveness: Civil Society Perspectives on Progress Since Paris. Quezon City: The Reality of Aid.

King, Alison, Rustamova, Mehriniso and Sobitov, Khiloldin. 2014. UNFPA Tajikistan Country Programme 2010-2015. Evaluation Report. Dushanbe: UNFPA.

Kobzar, Elena. 2007. Gender Equality in the Agricultural Sector. Dushanbe: United Nations Development Fund for Women (UNIFEM) and Canadian International Development Agency (CIDA).

Krylova, Lena and Safarova, Nigora. 2013. Gender Assessment: SDC Rural Drinking Water Program in Tajikistan. Dushanbe: Swiss Agency for Development and Cooperation (SDC).

Kuddusov, Jamshed. 2010. Labor Market Review Tajikistan. Turin: European Training Foundation.

_. 2010. Migration Survey: Migration and Skills in Tajikistan. Turin: European Training Foundation.

Kurbanov, S. 2013. Gender Shape of Labor Migration in the Republic of Tajikistan. Dushanbe: Agency for Statistics under the President of Tajikistan.

Kuvatova, Alla. 2001. Gender Issues in Tajikistan: Consequences and Impact of the Civil War. Hommes Armés - Femmes Aguerries, 127-136. Graduate Institute of Development Studies.

League of Women Lawyers of the Republic of Tajikistan. 2012. Short Survey on Implementation of Gender-Sensitive Law by Judges in Selected Regions. Committee on Women's and Family Affairs: Dushanbe. [in Russian]. 
Maltseva, Irina. 2007. Gender Equality in the Sphere of Employment. Dushanbe: UNIFEM.

Mamadazimov, Abdughani and Kuvatova, Alla. 2011. Political Party Regulations and Women's Participation in Political Life in Tajikistan. Dushanbe: National Association of Political Scientists of Tajikistan.

Mediterranean Institute of Gender Studies. 2009. Glossary of Gender-Related Terms 6-7. http://www.medinstgenderstudies.org/publications/glossary-on-gender.

Melikyan, Lilit, and Ghukassyan, Hasmik. 2011. Poverty and Social Impact Assessment: Energy Sector in Tajikistan. Dushanbe: UNDP.

Migrant. Ferghana.ru. 2015. Official Data from FMS Dispels Rumors of Mass Departure of Labor Migrants from Russia. 23 January. http://migrant.ferghana.ru/tag/statistika. [in Russian].

— 2014. Russia: The Number of Citizens of Central Asian Countries has Decreased Compared to the Summer. 08 December. http://migrant.ferghana.ru/tag/statistika. [in Russian].

Ministry of Education and Science of the Republic of Tajikistan. 2014. Statistical Collection of Education Sphere of the Republic of Tajikistan. Dushanbe.

Mirzoev, Shuhrat. 2014. Joint Sector Review Report. Dushanbe: Ministry of Education and Science and UNICEF.

Mukhamedova, Nozilakhon and Wegerich, Kai. 2014. Land Reforms and Feminization of Agricultural Labor in Sughd Province, Tajikistan. Colombo: International Water Management Institute (IWMI).

M-Vector Research and Consulting. 2013. Women Rule! The Transformation of the Role of Women in Tajikistan. 28 August. http://www.m-vector.com/ru/news/?id=318. [in Russian].

National Association of Business Women of Tajikistan (NABWT). 2010. Safe Markets and Cross-Border Trade for Women in Tajikistan. Khujand.

—_. 2014. Farah-2014 Journal. Khujand.

Nourzhanov. Kirill. 2013. Tajikistan: A Political and Social History. Canberra: Australian National University E Press.

Olimova, Saodat. 2012. Tajikistan: The Role and Status of Women in Migrant Households. Diaspora. No. 2. http://www.demoscope.ru/weekly/2014/0583/analit01.php\#_FNR_1.

Olimova, Saodat and Mamagzhanova, Nigina. 2006. Trafficking in Persons in Tajikistan. International Organization for Migration (IOM) and Sharq Research Center:

Dushanbe. [in Russian] 
Organization for Economic Co-Operation and Development (OECD). Social Institutions and Gender Index, Tajikistan.

Organization for Security and Co-operation in Europe (OSCE) Office in Tajikistan. 2010. Climate Change Survey in Tajikistan. Dushanbe.

OSCE/ODIHR. 2010. Republic of Tajikistan Parliamentary Elections 28 February 2010, Election Observation Mission Final Report. Warsaw.

Pandya, Ashley and Wilkinson, Kate. 2011. A Seat at the Table: The Role of Microfinance in Women's Economic Empowerment in Tajikistan.

Parshin, Konstantin. 2013. Tajikistan: Surprise Presidential Candidate Shakes Up Political Scene. Eurasianet.org. 25 September. http://www.eurasianet.org/node/67549

Population Services International Research and Metrics. 2012. Central Asia Republics: HIV and TB TRaC study understanding risk behaviors associated with HIV transmission and utilization of HIV prevention services among SWs in Almaty (Kazakhstan), Chui Oblast (Kyrgyzstan), and Dushanbe (Tajikistan). Washington, DC.: USAID.

Sattar, Sarosh. 2012. Opportunities for Men and Women: Emerging Europe and Central Asia. Washington, DC.: World Bank.

Sattar, S., Bierbaum, M., Barfieva, S., Flanaga, J., Lakhani, S., and Swinkels, R. 2013. Tajikistan Gender Diagnostics Note. Report No: ACS5015. Washington DC.: World Bank.

Save the Children. 2011. Child Protection Situational Analysis in Tajikistan. Dushanbe.

Sharipova, G., and Babajanova, I. 2010. The Safety of Women Entrepreneurs at Markets: Results of a Safety Audit. Khujand: National Association of Business Women of Tajikistan. [in Russian].

Shoshina, Ekaterina. 2013. Tajik Marriage Reform Misfires. Institute for War and Peace Reporting. 26 July. https://iwpr.net/global-voices/tajik-marriage-reform-misfires

Silova, Iveta and Abdushukurova, Tatiana. 2009. Global norms and local politics: uses and abuses of education gender quotas in Tajikistan. Globalisation, Societies and Education. Vol. 7, No. 3. London.

Sokieva, Gulafshon. 2012. Tajik Women Hit Glass Ceiling. Institute for War and Peace Reporting. 23 July. https://iwpr.net/global-voices/tajik-women-hit-glass-ceiling

Tandon, Nidhi. 2011. Climate Change: Beyond Coping. Women Smallholder Farmers in Tajikistan. Oxford: Oxfam GB.

Trilling, David. 2013. Tajikistan's Opposition Challenger Forced Out of Presidential Race. Eurasianet.org. 11 October. http://www.eurasianet.org/node/67616 
UNICEF. 2011. Impact of Labour Migration on “Children Left Behind in Tajikistan.” Dushanbe: Oxford Policy Management.

—_. 2013. Global Initiative on Out-of-School Children: Tajikistan Country Study. Dushanbe.

- 2013. Study of Prevalence and Dynamics of Suicide among Children and Young People (12-24 Years of Age) in Sughd Region, Tajikistan. Dushanbe.

United Nations Committee on the Elimination of Discrimination against Women. 2013. Concluding observations on the combined fourth and fifth periodic reports of Tajikistan. CEDAW/C/TJK/CO/4-5. Geneva.

UNIFEM and ILO. 2009. A Needs Assessment of Women Migrant Workers. Central Asia and Russia. Almaty.

United Nations Development Programme (UNDP). 2010. Human Development Report 2010, The Real Wealth of Nations: Pathways to Human Development. New York.

—. 2007. Gender Mainstreaming in Practice: A Toolkit ( $3^{\text {rd }}$ Edition). Bratislava.

- 2010. National Human Development Report 2008-2009: Employment in the Context of Human Development. Dushanbe.

_- 2011. Human Development Report 2011-Sustainability and Equity: A Better Future for All. New York.

- 2014. Human Development Report 2014-Sustaining Human Progress: Reducing Vulnerabilities and Building Resilience. New York.

United Nations General Assembly. 1993. Declaration on the Elimination of Violence against Women, Resolution A/RES/48/104, Article 1. http://www.un.org/documents/ga/res/48/ a48r104.htm

United Nations Human Rights Council. 2009. Report of the Special Rapporteur on Violence Against Women, Its Causes and Consequences. Yakin Ertürk, Addendum Mission to Tajikistan. Geneva.

United Nations Office in Tajikistan. 2010. Millennium Development Goals, Tajikistan Progress Report. Dushanbe.

—_. 2013. Tajikistan Report of Post - 2015 National Consultations. Dushanbe.

—_. 2014. UN Tajikistan Bulletin. Dushanbe.

United Nations Population Fund (UNFPA). 2014. Child Marriage in Tajikistan. http://eeca. unfpa.org/publications/child-marriage-tajikistan-summary 
United States Agency for International Development (USAID). 2014. The 2013 CSO Sustainability Index for Central and Eastern Europe and Eurasia. Washington, DC.

United States Department of State. 2013. Country Reports on Human Rights Practices for 2013: Tajikistan. Washington, DC.

_. 2013. Human Rights and Labor. International Religious Freedom Report for 2013. Washington, DC.

_. 2013. International Religious Freedom Report for 2013. Washington, DC.

—. 2014. Trafficking in Persons Report. Washington, DC.

Weine, Stevan, Bahromov, Mahbat, Loue, Sana, and Owens, Linda. 2013. HIV Sexual Risk Behaviors and Multi-Level Determinants Among Male Labor Migrants from Tajikistan. Journal of Immigrant and Minority Health. Vol. 15(4). pp. 700-710.

World Bank. 2009. Agricultural Activities, Water, and Gender in Tajikistan's Rural Sector: A Social Assessment of Konibodom, Bobojon Ghafurov, and Yovon. Dushanbe.

_- 2013. Migration and Remittance Flows in Europe and Central Asia: Recent Trends and Outlook, 2013-2016. 02 October. http://www.worldbank.org/en/news/ feature/2013/10/02/migration-and-remittance-flows-in-europe-and-central-asiarecent-trends-and-outlook-2013-2016.

_- 2014. Assessment of Household Energy Deprivation in Tajikistan. Policy Options for Socially Responsible Reform in the Energy Sector. Washington, DC.

_- 2014. Tajikistan. Autonomous Adaptation to Climate Change: Economic Opportunities and Institutional Constraints for Farming Households. Washington DC.

World Economic Forum. 2014. Gender Gap Index. Tajikistan. http://reports.weforum.org/ global-gender-gap-report-2014/economies/\#economy=TJK

World Health Organization (WHO). Progress in the Prevention of Injuries in the WHO European Region: Tajikistan. http://www.euro.who.int/__data/assets/pdf_ file/0003/86826/Tajikistan.pdf?ua=1

- 2009. Global Status Report on Road Safety: Country Profiles. Geneva.

_- 2011. Intimate Partner and Sexual Violence against Women, Fact Sheet No. 239. http://www.who.int/mediacentre/factsheets/fs239/en/index.html

__. 2013. Global Status Report on Road Safety: Country Profiles. Geneva.

Yusufbekov Yusuff, Babajanov Rustam, and Kuntuvdiy Natalya. 2007. Civil Society Development in Tajikistan. Dushanbe: Aga Khan Development Network. 


\section{Tajikistan: Country Gender Assessment}

The resurgence of conservative patriarchal values in Tajikistan have led to the rise of early marriages and polygamy, compromising women's and girls' opportunities to realize their full potential to live quality lives, and have deterred women from fully participating in and benefitting from development. This country gender assessment report re-examines the gender equality situation in the country, identifies critical gender issues such as gender-based barriers to economic opportunities, social services, and to leadership and decision-making posts. The report also provides sector-specific gender analyses and identifies entry points for mainstreaming gender in agriculture and natural resources, education, energy, entrepreneurship and SME development, and transport.

\section{About the Asian Development Bank}

ADB's vision is an Asia and Pacific region free of poverty. Its mission is to help its developing member countries reduce poverty and improve the quality of life of their people. Despite the region's many successes, it remains home to the majority of the world's poor. ADB is committed to reducing poverty through inclusive economic growth, environmentally sustainable growth, and regional integration.

Based in Manila, ADB is owned by 67 members, including 48 from the region. Its main instruments for helping its developing member countries are policy dialogue, loans, equity investments, guarantees, grants, and technical assistance. 